\title{
Purinergic signalling in the kidney in health and disease
}

\author{
Geoffrey Burnstock • Louise C. Evans • \\ Matthew A. Bailey
}

Received: 16 August 2013 / Accepted: 24 October 2013 /Published online: 22 November 2013

(C) Springer Science+Business Media Dordrecht 2013

\begin{abstract}
The involvement of purinergic signalling in kidney physiology and pathophysiology is rapidly gaining recognition and this is a comprehensive review of early and recent publications in the field. Purinergic signalling involvement is described in several important intrarenal regulatory mechanisms, including tuboglomerular feedback, the autoregulatory response of the glomerular and extraglomerular microcirculation and the control of renin release. Furthermore, purinergic signalling influences water and electrolyte transport in all segments of the renal tubule. Reports about purine- and pyrimidine-mediated actions in diseases of the kidney, including polycystic kidney disease, nephritis, diabetes, hypertension and nephrotoxicant injury are covered and possible purinergic therapeutic strategies discussed.
\end{abstract}

Keywords Glomerulus · Tubules · Sodium transport · ATP release $\cdot$ Kidney failure $\cdot$ Diabetes

\section{Synopsis}

\section{Glomerulus and the renal vasculature}

Mesangial cells

Podocytes

G. Burnstock $(\bowtie)$

Autonomic Neuroscience Centre, University College Medical

School, Rowland Hill Street, London NW3 2PF, UK

e-mail: g.burnstock@ucl.ac.uk

G. Burnstock

Department of Pharmacology, The University of Melbourne,

Parkville 3010, Melbourne, Australia

L. C. Evans • M. A. Bailey

University/British Heart Foundation Centre for Cardiovascular

Science, The University of Edinburgh, Edinburgh, UK
Kidney blood vessels

Physiological responses in the glomerulus and renal vasculature

Renal autoregulation

Myogenic responses to altered perfusion pressure

Tubuloglomerular feedback and the juxtaglomerular

apparatus

Glomerular and medullary microcirculation

Renin release

\section{Renal tubules}

Proximal convoluted tubules

Loop of Henle

Distal tubules

Collecting duct

Water transport

Sodium transport

\section{Release and metabolism of nucleotides}

Flow-induced nucleotide release

Mechanism of nucleotide release

Metabolism by ectonucleotidases

\section{Renal pathophysiology}

Renal injury and failure

Polycystic kidney disease

Ischaemia

Nephritis

Hypertension

Diabetic nephropathy

Inflammation

Hyper- and hypothyroidism

Nephrotoxicant injury

Renal transplants

\section{Summary}


Studies of the involvement of purinergic signalling in kidney physiology and pathophysiology are growing rapidly, so we believe it is timely to prepare a comprehensive review of the history and current views about the wide variety of events mediated by receptors for purines and pyrimidines. Reviews are available on various aspects of the field, including:

Adenosine and regulation of renin secretion [159,273];

Adenosine and kidney function [69,248,259,349,384];

Glomerulus and tuboglomerular feedback $[148,200$, 255,320];

Nucleotide signalling along the renal tubules (sodium and water transport) $[12,28,77,103,192,215,216,233,288,297$, 308,328,372,381,383,409,414];

Cilia in renal epithelium and paracrine purinergic signalling [298];

Nervous control (ATP as a cotransmitter) [306];

Ectonucleotidases in the kidney [333];

Purinergic regulation of renal blood flow $[45,146,147$, 150,153,165,256,261,321];

P2X receptors and kidney function [17].

Pathophysiology [30,113,402,403];

Physiological and pathophysiological renal actions of purines [113,118,160,161,217,379,402,403];

Polycystic kidney disease (PKD) [133,139,267];

Role of dinucleotide polyphosphates in chronic kidney disease and uremia [171].

Renal microvascular function and hypertension [117].

Sympathetic hyperactivity in renal disease [6];

Mechanotransduction in the renal tubule [400].

Human embryonic kidney (HEK-293) cells are often used as a recombinant expression system for the study of a variety of receptors, including $\mathrm{P} 2$ receptors (see e.g. [7,68,334,374]), even though they express native $\mathrm{P}_{2} \mathrm{Y}_{1}, \mathrm{P}_{2} \mathrm{Y}_{2}$ and $\mathrm{P} 2 \mathrm{Y}_{4}$ receptors $[88,89]$.

\section{Glomerulus and the renal vasculature}

The mammalian glomerulus is structurally complex, consisting of central glomerular tuft of endothelial ( $20 \%$ of total cells) and mesangial ( $\sim 25 \%)$ cells, encapsulated by a double layer of visceral (podocytes) and parietal epithelial ( $\sim 55 \%$ ) cells ([266]; see Fig. 1). Most information concerning P2 receptor expression in the glomerulus comes from cell culture with very few studies on receptor distribution in the native mammalian glomerulus. Nevertheless, mRNA for $\mathrm{P} 2 \mathrm{Y}_{1}$ and $\mathrm{P} 2 \mathrm{Y}_{2}$ was identified in extracts from whole rat glomeruli [16]. $\mathrm{P}_{2} \mathrm{Y}_{2}$ immunoreactivity colocalised with podocytes and cells of the parietal sheets; $\mathrm{P}_{2} \mathrm{Y}_{1}$ immunoreactivity was limited to the mesangial cells. ATP evoked calcium transients in the intact glomerulus and in the isolated parietal sheet. These studies suggest that extracellular ATP may regulated glomerular ultrafiltration directly, independent of actions of the renal microvasculature. ATP can also relax glomeruli via P2Y receptors on endothelial cells resulting in release of nitric oxide (NO), supporting the notion that $\mathrm{P} 2$ receptors influence glomerular filtration rate (GFR) [166]. Uridine adenosine tetraphosphate may also act as an autocrine hormone affecting glomerular filtration rate [170]. Tubular sodium transport systems are more sensitive to diadenosine tetraphosphate $\left(\mathrm{Ap}_{4} \mathrm{~A}\right)$ than systems involved in glomerular filtration rates [167]. $\beta$-Blockers induce relaxation of the glomerular microvasculature by releasing ATP, which acts via $\mathrm{P} 2 \mathrm{Y}$ receptors on endothelial cells to produce NO, resulting in vasodilation [180]. Connexin (Cx) 40 hemichannels and extracellular ATP are the key molecular elements of the glomerular endothelial calcium wave [371]. A review that discusses the roles of ATP and adenosine in tubuloglomerular feedback (TGF) regulation of glomerular filtration is available [46]. In addition to the effects of GFR, P2 receptors in the extraglomerular mesangium play an important role in TGF, as discussed below.

\section{Mesangial cells}

Functionally, ATP and uridine 5'-triphosphate (UTP), probably acting via $\mathrm{P} 2 \mathrm{Y}_{2}$ and/or $\mathrm{P}_{2} \mathrm{Y}_{4}$ receptors, increased inositol 1,4,5-trisphosphate formation and activated the p38-stressactivated protein kinase cascade in rat renal mesangial cells $[144,286,361]$. Extracellular ATP increases $\left[\mathrm{Ca}^{2+}\right]_{\mathrm{i}}$ by release from intracellular stores, indicating mediation via $\mathrm{P} 2 \mathrm{Y}$ receptors [121,282], although P2X receptor-mediated increase in $\left[\mathrm{Ca}^{2+}\right]_{\mathrm{i}}$ has also been claimed [311]. Cultured mouse mesangial cells expressed $\mathrm{P} 2 \mathrm{X} 2, \mathrm{P} 2 \mathrm{X} 4, \mathrm{P} 2 \mathrm{X} 7, \mathrm{P}_{2} \mathrm{Y}_{2}$ and $\mathrm{P}_{2} \mathrm{Y}_{4}$ receptors; mRNA (but not protein) for $\mathrm{P} 2 \mathrm{X} 1$ and $\mathrm{P} 2 \mathrm{X} 3$ receptors was also found [311]. Using RT-PCR, P2X1 receptor mRNA was shown to be expressed by an immortalised mouse mesangial cell line (G3) [131]. ATP and UTP stimulate the mitogen-activated protein kinase (MAPK) cascade and the MAPK pathway to promote proliferation of rat renal mesangial cells $[143,145,157,323,392]$. Extracellular ATP causes apoptosis and necrosis of cultured mesangial cells via $\mathrm{P} 2 \mathrm{X} 7$ receptors [326], although $\mathrm{P} 2 \mathrm{X} 4$ receptors may also be involved in the apoptotic actions [347]. The generation of reactive oxygen species in rat mesangial cells may contribute to P2X7 receptor-induced apoptotic cell death [125]. ATP potentiates mesangial cell proliferation induced by growth factors [324] and growth hormones reverse desensitization of $\mathrm{P}_{2} \mathrm{Y}_{2}$ receptors in rat mesangial cells [122].

Diadenosine polyphosphates, which influence renal perfusion pressure, activate $\mathrm{Cl}^{-}$and non-selective cation conductance in rat mesangial cells as do ATP and angiotensin II (Ang II); $\mathrm{Ap}_{4} \mathrm{~A}$ was the most effective of the dinucleotides [194,318,325]. Diadenosine pentaphosphate $\left(\mathrm{Ap}_{5} \mathrm{~A}\right)$ and diadenosine hexaphosphate appear to play a regulatory role in mesangial cell proliferation [129]. $\mathrm{Ap}_{4} \mathrm{~A}$ and $\mathrm{Ap}_{5} \mathrm{~A}$ 
Fig. 1 Schematic showing the structural and functional relationships within the JGA. The macula densa (MD) cells are shown in brown, the extraglomerular mesangium in blue, the vascular smooth muscle cells (VSMCs) in magenta, the renin-producing cells in green, the fibroblasts of the adjacent interstitium in yellow and the blood vessels in red. Note that both signalling pathways from the MD pass the extraglomerular mesangium, either to reach the VSMCs $(I)$ to regulate filtration or the renin-producing cells $(I I)$ to mediate renin secretion (reproduced from [200], with permission from the American Society for Clinical Investigation)

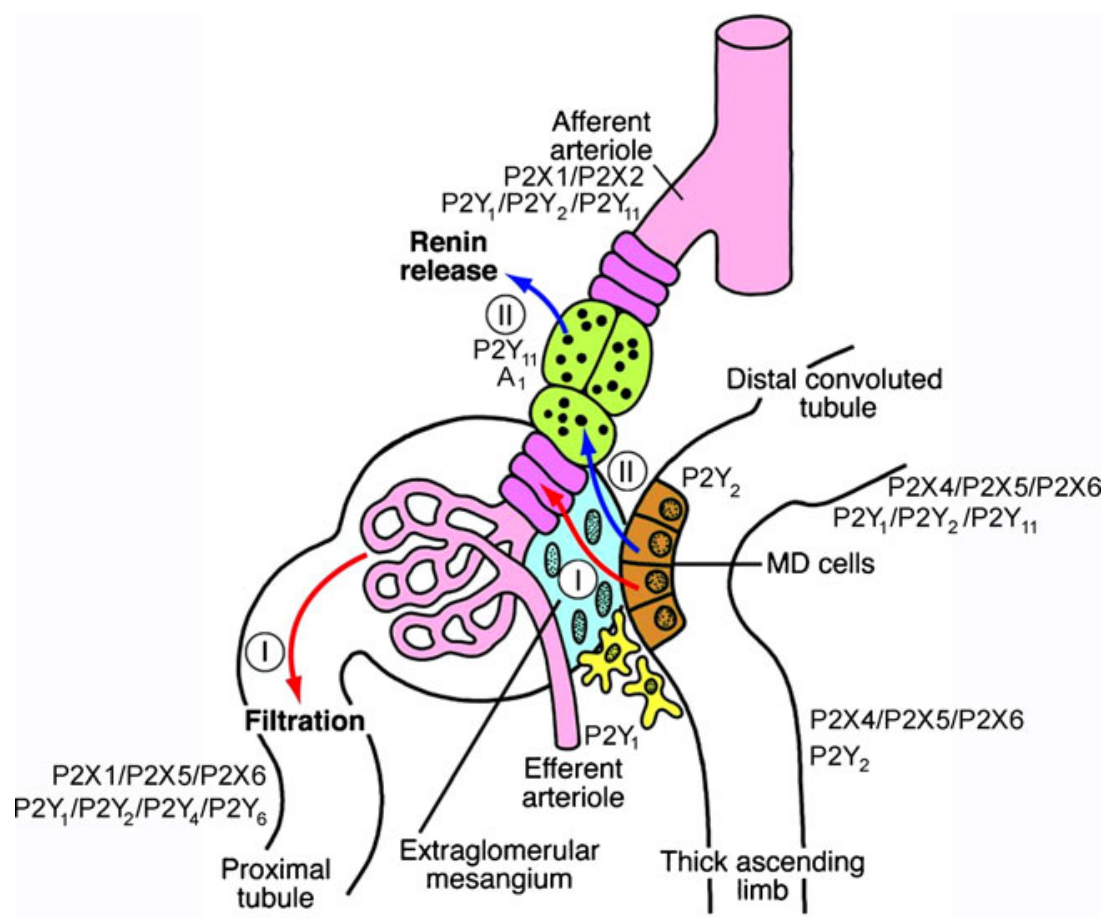

decrease, while diadenosine triphosphate appears to increase glomerular filtration rate [359].

The effect of sphingosine-1-phosphate, a potent mitogen of mesangial cells, is rapidly desensitized by activation of $\mathrm{P} 2 \mathrm{Y}$ and P1 receptors [420]. ATP and UTP induce migration of mesangial cells by upregulating sphingosine kinase-1 expression and activity [193].

Adenosine inhibits platelet-derived growth factor in human glomerular mesangial cells via $A_{2 B}$ receptors [73]. $A_{1}$ and $A_{2}$ receptors appear to mediate opposite actions on intracellular levels of cyclic adenosine monophosphate (cAMP) in mesangial cells [265]. $A_{2}$ receptor-mediated hyperpolarisation of cultured rat mesangial cells has been described [283]. $A_{2}$ receptors have been identified on human glomerular mesangial cells [350]. Adenosine activates mesangial cell proliferation [235], but can also induce apoptosis of mesangial cells [437]. High concentrations of glucose increase extracellular levels of ATP in mesangial cells, which in turn activates ERK1/2. This effect is partially dependent on the generation of reactive oxygen species and subsequent upregulation of transforming growth factor- $1 \beta[300]$.

\section{Podocytes}

Podocytes maintain the permselectivity of the glomerular filtration barrier. Podocyte function is implicated in human health: proteinuria is a significant independent risk factor for cardiovascular mortality and an indicator of underlying chronic kidney disease. Cultured human podocytes produce superoxide in response to extracellular ATP [115]. Increase in
$\left[\mathrm{Ca}^{2+}\right]_{\mathrm{i}}$ by purines and pyrimidines is mediated mainly by $\mathrm{P}_{2} \mathrm{Y}_{2}$ and $\mathrm{P} 2 \mathrm{Y}_{6}$ receptors, but $\mathrm{P} 2 \mathrm{Y}_{1}, \mathrm{P}_{2} \mathrm{Y}_{11}$ and $\mathrm{P} 2 \mathrm{X} 7$ receptors are also expressed by podocytes [40,87,118,375]. ATP acting via $\mathrm{P} 2$ receptors stimulated AMP-activated protein kinase and suppressed superoxide generation in cultured mouse podocytes [287]. Functionally, activation of $A_{2 \mathrm{~A}}$ receptors reduces glomerular proteinuria at least in part by preserving the structure and function of podocytes [9].

\section{Kidney blood vessels}

P2X1 receptors have been identified in the vascular smooth muscle of the rat renal, arcuate and interlobular arteries and in the afferent arteriole: P2X1 is not expressed in the efferent arteriole [51,375]. A P2X1-like receptor has been confirmed functionally in the afferent arteriole [149]. In the smooth muscle of the larger renal arteries, P2X2 receptor subunits have been immunolocalised [146,375], and at a molecular level, P2X4 receptor subunits are found, at least in arcuate and interlobular arteries [127]. At a protein level, however, $\mathrm{P} 2 \mathrm{X} 4$ expression is limited to the vascular endothelium [242]. P2X7 receptors are also expressed in the healthy kidney: expression in the vascular smooth muscle and outeradventitium is very low [218], whereas functionally significant expression is observed in the endothelium [242]. Of the $\mathrm{P} 2 \mathrm{Y}$ receptors, $\mathrm{P}_{2} \mathrm{Y}_{1}$ is expressed in the endothelium of the large arteries and both afferent and efferent arterioles [375]. ATP released from renal tubular epithelial cells acts on pericytes to regulate the diameter of vasa recta capillaries that are in close proximity to renal tubules and are key to 
regulating renal medullary blood flow [61]. P1 receptors are expressed on mouse afferent arterioles and it was concluded that activation of $\mathrm{A}_{3}$ receptors blunted the vasoconstrictor effects mediated by $A_{1}$ receptors [231].

Physiological responses in the glomerulus and renal vasculature

Infusion of ATP into the renal artery alters renal vascular resistance, although the vasoactive response is dependent upon species and basal vascular tone and can be influenced by the experimental approach [147]. Functionally, the larger renal arteries serve principally as conductance vessels [428], and renal vascular resistance, which determines renal blood flow, is regulated primarily through pressure-dependent vasoactivity of the preglomerular arterioles [351]. The interlobular arteries also contribute, but to a lesser extent [130]. The responsiveness to ATP of the arcuate and interlobular arteries and the glomerular arterioles of the rat has been assessed in the isolated perfused kidney preparation [149]. The preglomerular arteries were relatively insensitive to ATP, with micromolar concentrations required to cause a short-lived vasoconstriction. In contrast, sub-micromolar concentrations of ATP caused sustained contraction of the afferent arteriole. The efferent arteriole was unresponsive to extracellular ATP, consistent with the reported absence of $\mathrm{P} 2$ receptors in this section. In the isolated perfused rat kidney, intrarenal administration of ATP is normally vasoconstrictive, an effect potentiated by inhibition of NO synthesis (NOS) [79]. In contrast, ATP causes vasodilatation when baseline renal vascular resistance is high. This reflects P2Ymediated production of $\mathrm{NO}$ [86]. More recent data have shown vasoactive actions of $\mathrm{P} 2 \mathrm{X} 4$ and/or $\mathrm{P} 2 \mathrm{X} 7$ in the rat renal artery [242]. It would appear that $\mathrm{P} 2$ receptor 'tone' influences renal vascular resistance, with P2Y-mediated vasodilatation opposing $\mathrm{P} 2 \mathrm{X}$-mediated vasoconstriction.

\section{Renal autoregulation}

Autoregulation of blood flow is an intrinsic property of most vascular beds. In the kidney, autoregulation is highly efficient so that renal blood flow is effectively independent of blood pressure over the physiological range [64]. Whole kidney autoregulation is governed through the combined influence of TGF and the intrinsic myogenic response of the vascular smooth muscle. These regulatory systems have overlapping operational frequencies and may interact to a degree [394] so that afferent arteriolar constriction through TGF enhances the myogenic response in the upstream vasculature [135].

\section{Myogenic responses to altered perfusion pressure}

The intrinsic myogenic response to altered perfusion pressure is both necessary and sufficient for full whole kidney autoregulation [64]. The myogenic response operates along the preglomerular vascular tree, with increased transmural pressure causing channel-mediated calcium influx and promoting reflex vasoconstriction of the vascular smooth muscle. Mechanistically, the underlying signalling processes are not fully defined, but local release of ATP is implicated. In the afferent arteriole, for example, pressure-mediated vasoconstriction is markedly blunted by pyridoxalphosphate-6azophenyl-2',4'-disulfonic acid (PPADS) or suramin or by the saturation and subsequent desensitization of the $\mathrm{P} 2$ receptor system [151]. The central role of the P2 system is further suggested by the fact that pressure-induced reductions in afferent arteriole diameter are abolished in P2X1-deficient mice [152]. Pharmacological [272] or pathological [119] manoeuvres that impair P2X1 receptor signalling will also blunt whole kidney autoregulation of blood flow, both in vivo and in vitro. Finally, mice with a targeted deletion of the ectonucleotidase NTPDase1 exhibit enhanced pressureinduced vasoconstriction in the mesenteric artery [183]. This probably reflects the prolonged half-life of extracellular ATP and is consistent with a key role for local nucleotide signalling in the general myogenic response.

\section{Tubuloglomerular feedback and the juxtaglomerular apparatus}

TGF is a dynamic process whereby changes in the concentration of $\mathrm{NaCl}$ in the fluid emerging from the loop of Henle elicit inverse changes in the GFR of the nephron of origin. TGF is mediated by the juxtaglomerular apparatus (JGA), which includes a sensor, the macula densa and an effector (granulated cells in the afferent arteriole); other components of the JGA (e.g. mesangial cells) also play a role.

Changes in luminal $\mathrm{NaCl}$ concentration within the physiological range promote a directly correlated release of ATP from the basolateral membrane of macula densa cells $[21,196]$. Furthermore, the concentration of ATP in the cortical interstitium changes to reflect inhibition or activation of TGF [260]. These data suggest that ATP is the primary signalling molecule for TGF $[22,258]$. Gene targeting experiments, however, indicate that ATP is not the ultimate signal through which activation of TGF causes constriction of the afferent arteriole: hydrolysis of ATP to adenosine appears to be critical. $A_{1}$ receptors mediate TGF in both rats [91] and mice [34]. In vivo TGF responses are blunted in mice lacking either the adenosine $A_{1}$ receptor $[222,356]$ or ecto-5'-nucleotidase, the enzyme catalysing the final stage of the degradation of ATP to adenosine [47]. This proposition is supported by a recent in vivo study in which the TGF response in mice (as assessed by changes in stop-flow pressure in the proximal tubule) was unaffected during intravenous infusion of PPADS or suramin [319]. Nevertheless, an anatomical consideration argues for involvement of the $\mathrm{P} 2$ receptor system in the TGF 
response: the ATP released from macula densa cells cannot activate directly $\mathrm{P} 2$ receptors in the afferent arteriole, being physically separated in most species by the extraglomerular mesangium. An intact mesangium is required for TGF responses [307]. Intracellular $\mathrm{Ca}^{2+}$ wave propagation occurs between rat juxtaglomerular cells; this is mediated by ATP and is involved in the synchronisation of renin release [424]. It was later shown that both ATP and gap junctions were integral components of the TGF calcium wave and that TGF activation causes a wave of increased cytosolic calcium to pass through the mesangium, to the granulated cells of the afferent arteriole and into the glomerular podocytes [285]. Propagation of this calcium wave was abolished by suramin but not by adenosine receptor antagonism. The P2 receptor response requires gap junctional coupling and is inhibited by antagonists against Cx37 and Cx40 [364]. It has been claimed recently that TGF adapts and stabilizes early distal delivery at a new set-point, via an $A_{1}$ receptor-dependent mechanism [27].
Finally, the basolateral membrane of macula densa cells expresses a $\mathrm{P}_{2} \mathrm{Y}_{2}$-like receptor. The function of this receptor is unknown but it may provide a mechanism through which ATP release can be coupled to production [22]. A schematic illustrating the underlying mechanism of TGF is shown in Fig. 2.

\section{Glomerular and medullary microcirculation}

Infusions of nucleotide analogues into the renal artery exert powerful effects on regional blood flow, and these can be measured by laser Doppler flow probes inserted into specific regions of the kidney. In the rabbit, ATP evokes a biphasic response, with vasoconstriction of the medullary blood flow being followed by hyperaemia [82]. On the basis of relative agonist potency, the vasoconstriction was attributed to P2X1 receptors; the secondary vasodilatation, which was independent of NO, to adenosine receptors. In the rat, the net effect of ATP is influenced by sodium status. In sodium-restricted rats,
Fig. 2 Proposed mechanism of adenosine acting as a mediator of the tubuloglomerular feedback. Numbers in circles refer to the following sequence of events. 1 , Increase in concentrationdependent uptake of $\mathrm{Na}^{+}, \mathrm{K}^{+}$and $\mathrm{Cl}^{-}$via the furosemide-sensitive $\mathrm{Na}^{+}-\mathrm{K}^{+}-2 \mathrm{Cl}^{-}$co-transporter (NKCC2); 2 and 3, transportdependent, intra- and/or extracellular generation of adenosine (ADO) and the extracellular generation involves ecto-5'-nucleotidase (5'-NT); 4 , extracellular ADO activates adenosine $\mathrm{A}_{1}$ receptors triggering an increase in cytosolic $\mathrm{Ca}^{2+}$ in extraglomerular mesangium cells (MC); 5, the intensive coupling between extraglomerular MC, granular cells containing renin and smooth muscle cells of the afferent arteriole (VSMC) by gap junctions allows propagation of the increased $\mathrm{Ca}^{2+}$ signal resulting in afferent arteriolar vasoconstriction and inhibition of renin release. Factors such as nitric oxide, arachidonic acid breakdown products or angiotensin (ANG) II modulate the described cascade. NOS I neuronal nitric oxide synthase, COX-2 cyclooxygenase- 2 (reproduced from [384], with permission of the American Physiological Society)
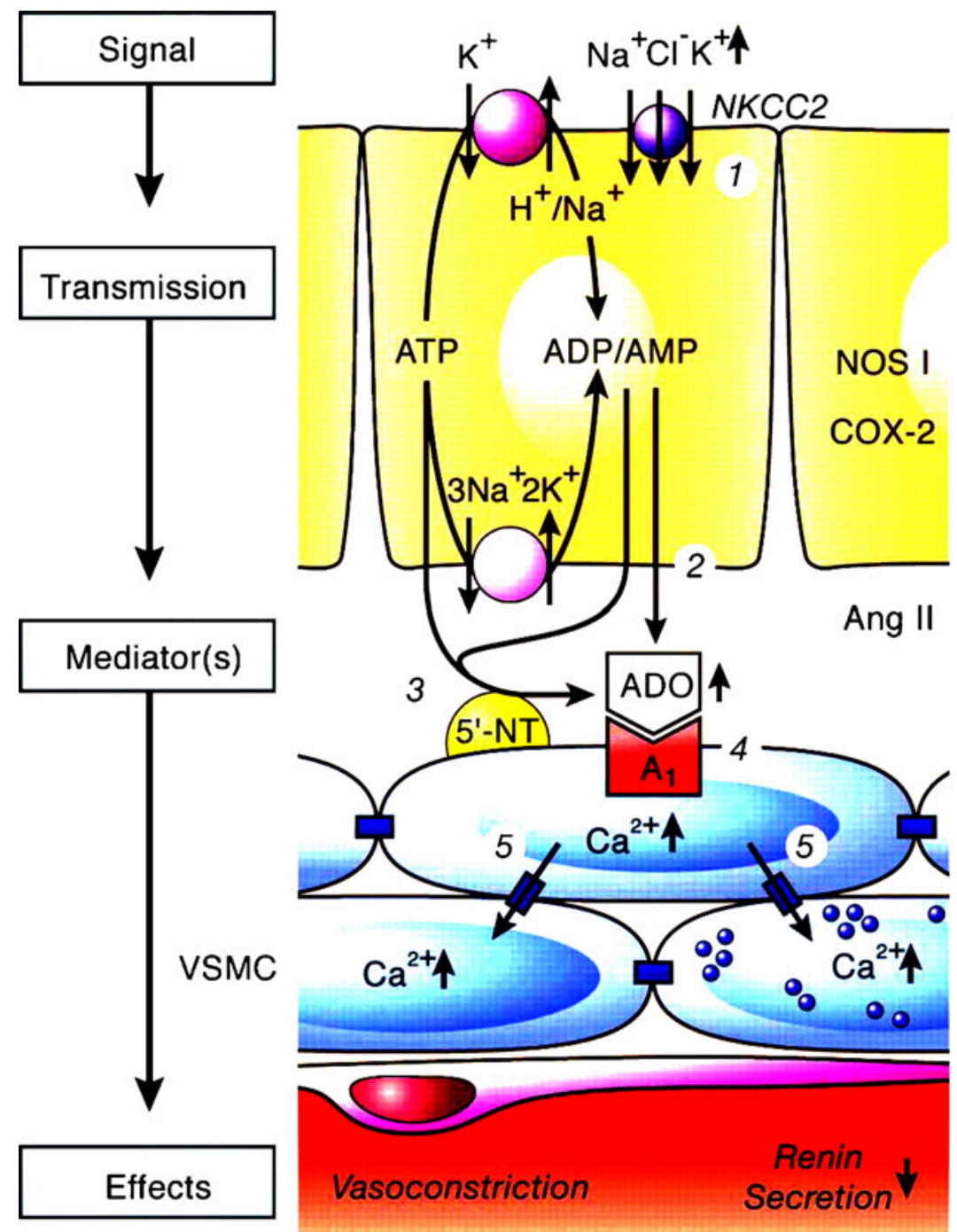

Tubule Lumen

Macula Densa

Interstitium

Extraglomerular MC

Granular Cells

Afferent
Arteriole 
ATP increased medullary blood flow in a NO-dependent manner [71]. In salt-loaded rats, ATP caused vasoconstriction in the outer medulla without affecting inner medullary flow. The authors speculated that the inner medullary vasodilatation reflected an effect of nucleotides on vasa recta pericytes. Consistent with this, purinergic cross-talk between the thick ascending limb and abutting vasa recta exerts a countervailing influence on Ang II vasoconstriction, an action lost during salt-sensitivity [263]. The integrated picture is far from clear, however, since data obtained in slices of rat kidney suggest that $\mathrm{P} 2$ receptor activation promotes vasoconstriction of the vasa recta due to contraction of pericytes [61].

Responses to adenosine, mediated by $\mathrm{A}_{2}$ receptors, modulated TGF by counteracting the effects of $A_{1}$ receptor-mediated actions [44]. Both $A_{2 A}$ and $A_{2 B}$ receptors are functionally expressed in juxtamedullary afferent arterioles, and the dilator effects of adenosine are predominantly mediated by $\mathrm{A}_{2 \mathrm{~B}}$ receptors, which counteract $A_{1}$ receptor-mediated vasoconstriction [84].

\section{Renin release}

The renin-angiotensin system is influenced by many factors, the final pathways of which converge at the level of altered intracellular calcium signalling in the granular cell; renin secretion is inversely related to $\left[\mathrm{Ca}^{2+}\right]_{\mathrm{i}}[424]$. The renin-containing epithelioid juxtaglomerular cells are modified vascular smooth muscle cells and are localised in the media of the afferent arteriole close to its entry into the glomerulus and are innervated by sympathetic nerves. ATP was shown to increase renin release from juxtaglomerular cells in an early paper [97]. Both renal juxtaglomerular and microvascular endothelial cells express P2 purinoceptors and ATP inhibited cAMP-stimulated renin release from juxtaglomerular cells only in the absence of endothelial cells [203]. P2Y receptors mediate stimulation of renin secretion in rat renal cortical slices [59]. ATP can stimulate the renin gene promoter via $\mathrm{P}_{2} \mathrm{Y}_{11}$ receptors [385]. Stimulation of sympathetic nerves released ATP as a cotransmitter with noradrenaline (NA) to elicit excitatory junction potentials in both smooth muscle and juxtaglomerular cells, to produce vasoconstriction and release of renin, respectively [38]. A recent paper reports that adenosine, formed during renal sympathetic nerve stimulation, enhances via $A_{1}$ receptors the postjunctional effects of released NA, thereby contributing to renal sympathetic neurotransmission [162]. Juxtaglomerular $A_{1}$ receptors are also involved in the control of the glomerular microcirculation [184]. Adenosine was shown to depress renin secretion in sodium-restricted rats, accompanied by a marked fall in GFR, while this effect was nearly abolished in sodium-loaded rats [274]. $\mathrm{A}_{2}$ receptors mediate arteriolar dilation and stimulation of renin secretion, whereas activation of $A_{1}$ receptors mediates arteriolar constriction and inhibition of renin secretion [58,252]. Adenosine inhibits renin release by a mechanism that involves the juxtaglomerular cells located in the afferent arteriole at some distance from the glomerulus [343]. From other studies, it was concluded that adenosine decreases renin release via the activation of juxtaglomerular $A_{1}$ receptors and that adenosine may be an inhibitory signal from the macula densa to juxtaglomerular cells [158,271]. In $\mathrm{A}_{1}$ receptor-deficient mice, TGF is abolished (see above) and there is increased plasma renin [34]. $A_{1}$ receptors are required for the inhibition of renin secretion produced by an increase in blood pressure, suggesting that adenosine is responsible for baroreceptor-mediated inhibition of renin release; in contrast, stimulation of the renin system by low blood pressure appears to follow a different pathway [327].

\section{Renal tubules}

The pattern and distribution of $\mathrm{P} 1[345,390]$ and $\mathrm{P} 2$ receptors $[14,49,375]$ along the rat renal tubule have been reported (see Fig. 3), and the major transporters for sodium and water are illustrated in Fig. 4. In recent years, our understanding of the functional consequences of receptor activation has advanced considerably, in part due to physiological studies in genetargeted mice (see Table 1).

\section{Proximal convoluted tubules}

P2Y receptors were identified in the renal cortex over 20 years ago [254], and since then, a variety of approaches has begun to catalogue the distribution of specific receptor subtypes. $\mathrm{P}_{2} \mathrm{Y}_{1}$ and $\mathrm{P} 2 \mathrm{X} 5$ receptors have been immunolocalised to the apical membrane in the $\mathrm{S} 3$ segment of the rat pars recta and $\mathrm{P}_{2} \mathrm{Y}_{4}$ and $\mathrm{P} 2 \mathrm{X} 6$ receptor protein is found basolaterally in the proximal convoluted tubule (PCT). Low level expression of P2X4 protein is also seen in the PCT but not ascribed to a specific membrane domain [375]. Western analysis has shown the $\mathrm{P}_{2} \mathrm{Y}_{1}$ receptors in brush-border membrane vesicles from the S2 segment of rat PCT [12].

mRNA has been identified for $\mathrm{P}_{2} \mathrm{Y}_{1,2,4}$ and 6 receptors in the rat proximal tubule $[14,15]$. Measurements of $\mathrm{Ca}^{2+}$ transients following application of $\mathrm{P} 2$ receptor agonists of varying selectivity support expression of apical $\mathrm{P}_{2} \mathrm{Y}_{1}$-like receptors in an immortalised cell line with a proximal phenotype [178] and for basolateral $\mathrm{P}_{2} \mathrm{Y}_{1}$ receptors in native rat PCT $[14,49]$. Bailey and colleagues [15] also reported that basolateral uridine $5^{\prime}$-diphosphate (UDP) was effective in increasing $\left[\mathrm{Ca}^{2+}\right]_{\text {, }}$, corroborating the presence of $\mathrm{P}_{2} \mathrm{Y}_{6}$ receptors. Finally, ATP and UTP were equipotent when applied to rat or rabbit basolateral membranes [14,422], implying $\mathrm{P}_{2} \mathrm{Y}_{2}$ or $\mathrm{P}_{2} \mathrm{Y}_{4}$ receptors. Notably, the immunohistochemical evidence in rats favours $\mathrm{P}_{2} \mathrm{Y}_{4}$ receptors [375].

In vivo, microperfusion studies show that adenosine nucleotides, applied from the luminal side, inhibited NHE3 activity in the rat PCT [11]. Adenosine diphosphate (ADP) was more effective than ATP, suggesting a $\mathrm{P}_{2} \mathrm{Y}_{1}$ receptor effect. This 


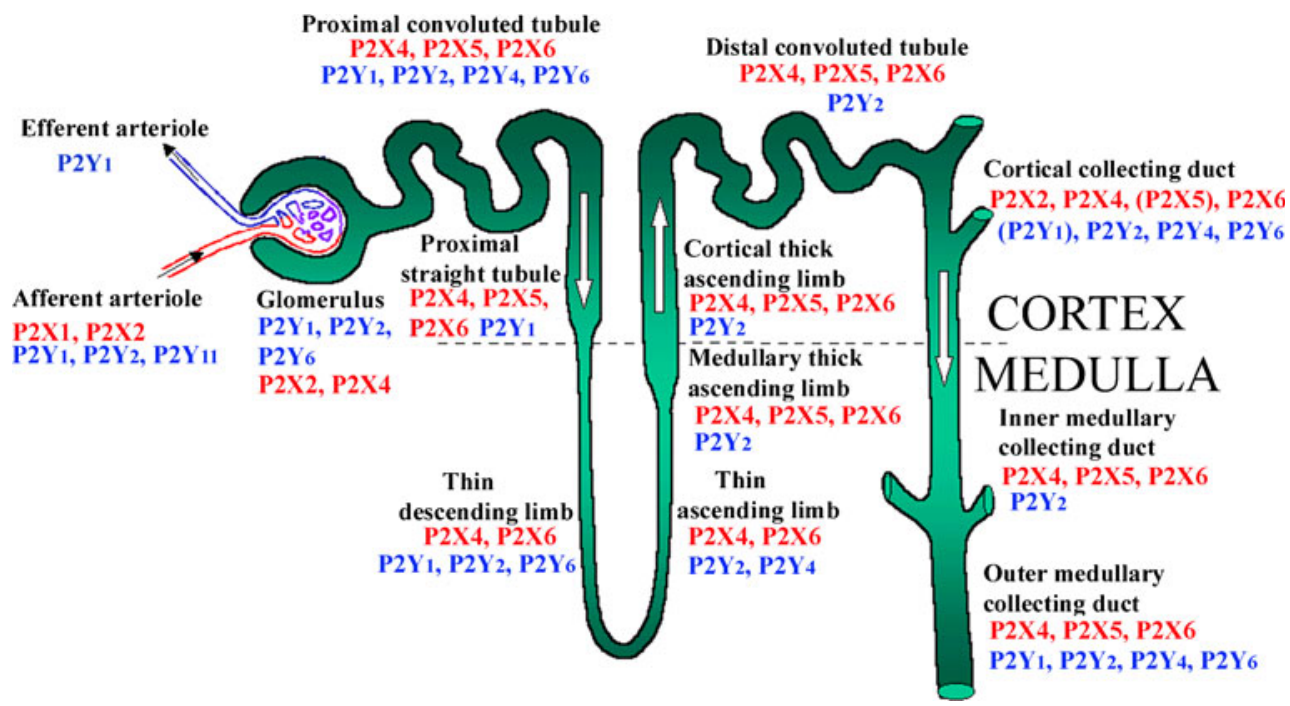

Fig. 3 The distribution of $\mathrm{P} 2$ receptors along the nephron: an amalgam of available functional, mRNA and protein (immuno-) detection studies showing how widespread and overlapping it is. To date, there has been no full report of their distribution in native renal tissue of any species.
$\mathrm{P} 2 \mathrm{Y}$ is shown in blue and $\mathrm{P} 2 \mathrm{X}$ in red; presence of those in parentheses is still uncertain. (updated from [381], with permission from the American Physiological Society) was supported by the observation that the $\mathrm{P} 2 \mathrm{Y}_{1}$-selective agonist 2-methylthio ADP also had a potent inhibitory effect, which was blocked by the $\mathrm{P}_{2} \mathrm{Y}_{1}$-selective antagonist MRS2179. Addition of ATP to peritubular capillaries in vivo caused an increase in transepithelial bicarbonate reabsorption in rat PCT [70]. Increasing the viscosity of the peritubular perfusate also stimulated bicarbonate reabsorption, and this effect was blocked by peritubular suramin, suggesting P2 receptor mediation. (Shear stress was proposed as the activating factor.) Interestingly, the increase in bicarbonate reabsorption induced by ATP or by raised viscosity could be blocked by a NOS inhibitor. Thus, P2 receptors exert in distinct membrane domains opposing effects on sodium bicarbonate flux. This complexity of paracrine regulation is also observed for Ang II.

In the proximal tubules of $\mathrm{P}_{2} \mathrm{Y}_{2}$ receptor knockout mice, the expression of NaPT2 protein is increased but NHE3 abundance is normal [225]. Consistent with this, ATP inhibits phosphate uptake (and mRNA for NaPT2) in primary cultures of rabbit PCTs [211]. In the same preparation, ATP stimulates sodium-glucose co-transport by increasing both SGLT1 and SGLT2 protein expression [210].

A study in rats, using lithium clearance as an index of end proximal tubular fluid delivery, reported that intravenous infusion of the diadenosine polyphosphate, $\mathrm{Ap}_{4} \mathrm{~A}$, increased lithium clearance almost twofold. This occurred despite a fall in GFR and suggested that proximal tubular reabsorption was markedly reduced [353]. Ap 4 A can stimulate a number of $\mathrm{P} 2$ receptor subtypes, including $\mathrm{P} 2 \mathrm{Y}_{1}$ and $\mathrm{P}_{2} \mathrm{Y}_{4}$ receptors $[331,410]$, which are both expressed in the rat proximal tubule ( $\mathrm{P} 2 \mathrm{Y}_{1}$ apically, $\mathrm{P}_{2} \mathrm{Y}_{4}$ basolaterally); intravenous delivery of the agonist does not allow differentiation between these possibilities.

Effects on transport have also been observed in the amphibian kidney. Cells of the frog proximal tubule contain at least two different $\mathrm{K}^{+}$-selective conductances, both of which are regulated by extracellular ATP [312]. Extracellular ATP raises cytosolic $\mathrm{Ca}^{2+}$ and activates basolateral chloride conductance in Necturus proximal tubules [32]. A more recent paper presented evidence that $\mathrm{P} 2 \mathrm{X} 1$ receptors played a role in the regulation of cell volume and $\mathrm{K}^{+}$channels in frog renal proximal tubule cells [66].

Adenine-based and uracil-based nucleotides can also regulate metabolic functions in the proximal tubule. Early papers showed that ATP inhibited citrate synthase activity in the kidney cortex [33] and stimulated tetraethylammonium transport by rabbit renal brush border membrane vessels [240]. Gluconeogenesis is also stimulated by $\mathrm{P} 2$ receptor activation $[48,247]$ and by diadenosine polyphosphates [75]. ATP and UTP were equipotent in stimulating gluconeogenesis, implicating $\mathrm{P}_{2} \mathrm{Y}_{2}$ or $\mathrm{P}_{2} \mathrm{Y}_{4}$ receptors [247]. Although these authors suggested $\mathrm{P} 2 \mathrm{Y}_{2}$ mediation, these receptors have not been found in rat proximal tubules. $\mathrm{P}_{2} \mathrm{Y}_{4}$ receptors are expressed here, making a basolateral $\mathrm{P}_{2} \mathrm{Y}_{4}$-mediated effect more likely.

A long-term trophic role for purinergic signalling in the kidney has also been described, where ATP stimulates proliferation of proximal tubule cells via increase in $\left[\mathrm{Ca}^{2+}\right]_{\mathrm{i}}$ and activation of $\mathrm{p} 38, \mathrm{p} 44 / 42$, MAPKs and cyclin-dependent kinase [212]. It has been claimed that there is paracrine stimulation of vascular smooth muscle proliferation by diadenosine polyphosphates released from proximal tubule cells [169], probably via P2Y receptors [39]. Tubular remodelling is 


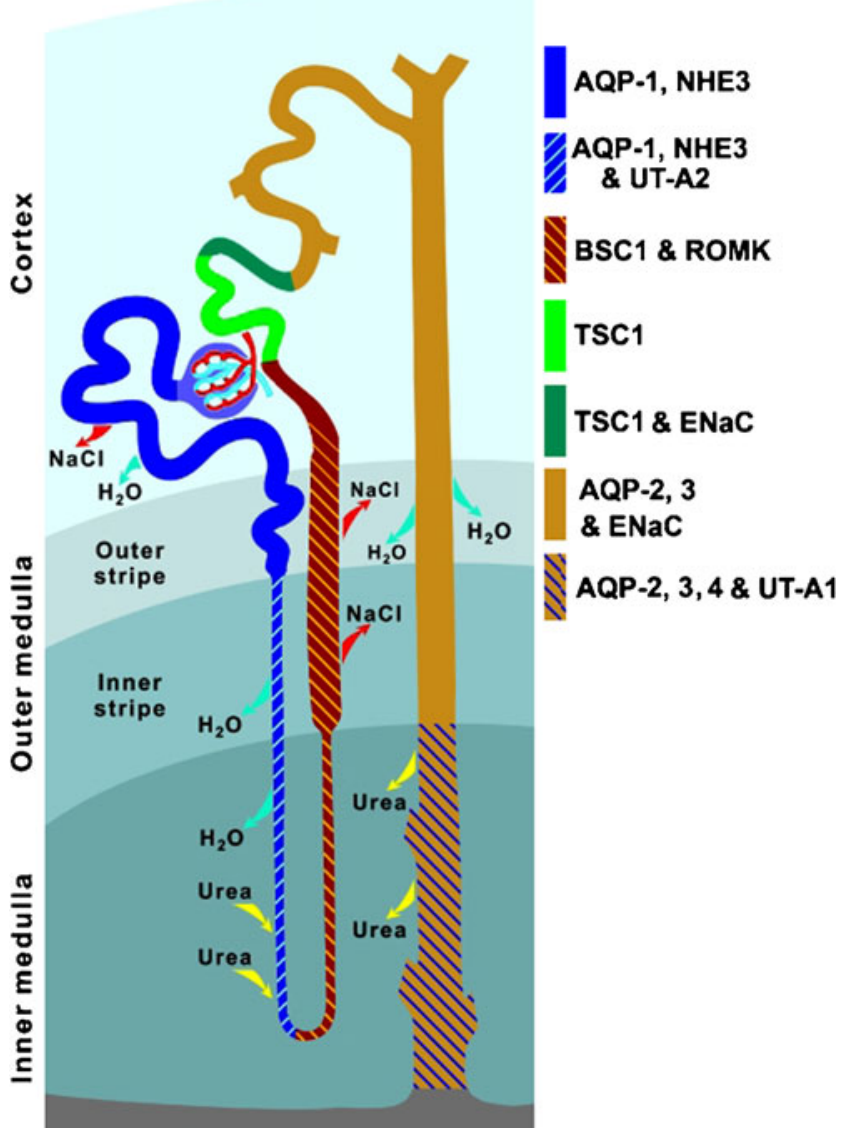

Fig. 4 Architecture of rat nephron and collecting duct showing segmental localisation of major transporters and channels that play critical roles in water and solute reabsorption. $A Q P 1, A Q P 2, A Q P 3, A Q P 4$ Aquaporin water channel isoforms (reproduced from [189] with permission from Springer)

complex, and in cultured mouse, proximal cells subjected to ATP depletion below $\sim 15 \%$ of control died uniformly of necrosis, while cells subjected to ATP depletion by $25 \%$ or more of controls all died by apoptosis [224]. Prior heat stress or $\mathrm{Zn}^{2+}$ inhibits apoptosis in ATP-depleted kidney proximal tubule cells [396,399]. Extracellular ATP protects cultured proximal tubule cells against oxidative stress [213].

Adenosine, acting via $\mathrm{P} 1$ receptors, also plays roles in the regulation of proximal tubule activity. Adenosine $A_{1}$ receptor mRNA was identified in rat nephron segments [423] and also $\mathrm{A}_{2 \mathrm{~A}}$ receptor mRNA [398]. Regulation of $\mathrm{Na}^{+}-3 \mathrm{HCO}_{3}{ }^{-}$cotransport in rabbit proximal tubules via $\mathrm{A}_{1}$ receptors was claimed [360]. $A_{1}$ receptors were characterised in human proximal tubule epithelial (HK-2) cells [367]. In the pig proximal tubule, $\mathrm{Na}^{+}$-ATPase activity is stimulated via adenosine $\mathrm{A}_{2 \mathrm{~A}}$ receptors, thus regulating sodium reabsorption [406]. Transepithelial fluxes of adenosine across human proximal tubule cells involve specific nucleoside transporters [80]. Adenosine is deaminated to inosine in isolated basolateral membranes from proximal tubules, leading to modulation of protein kinase (PK) A activity [8]. Low salt intake increases
$A_{1}$ receptor expression and function in rat proximal tubules [202]. Inhibition of $A_{1}$ receptors increases fluid uptake in the proximal tubule [278]. Adenosine-induced PKA activation reduced Ang II-induced stimulation of phosphoinositide specific phospholipase (PL) C $\beta$ [109].

The loop of Henle

P2X4 and P2X6 receptors have been immunolocalised to the rat thin descending limb of Henle [375]. Measurements of agonist-induced $\left[\mathrm{Ca}^{2+}\right]_{\mathrm{i}}$ transients indicate a functional pyrimidine receptor in the basolateral membrane of this segment [14], but neither $\mathrm{P}_{2} \mathrm{Y}_{2}$ nor $\mathrm{P}_{2} \mathrm{Y}_{4}$ protein has been demonstrated. mRNA for $\mathrm{P}_{2} \mathrm{Y}_{1}$ and $\mathrm{P}_{2} \mathrm{Y}_{6}$ is expressed here $[14,15]$, but again evidence of receptor protein is lacking. In the rat thin ascending limb, the functional evidence for a pyrimidine receptor in the basolateral membrane [14] is, in this case, supported by immunohistochemical confirmation of $\mathrm{P}_{2} \mathrm{Y}_{2}$ receptor protein; $\mathrm{P} 2 \mathrm{X} 4$ and $\mathrm{P} 2 \mathrm{X} 6$ protein expression has also been reported [375]. The physiological role of $\mathrm{P} 2$ receptors in the thin limbs is unknown, but this reflects the general absence of information regarding transport in these segments.

The expression and function of $\mathrm{P} 2$ receptors in the thick ascending limb (TAL) is increasingly well-defined but there appear to be species differences between rat and mouse. In the rat TAL, basolateral binding sites for adenosine- 5 '- $(\gamma$-thio)triphosphate (ATP $\gamma \mathrm{S})$ are found [13], but this agonist does not discriminate well between different receptor (both P2Y and $\mathrm{P} 2 \mathrm{X}$ ) subtypes. $\mathrm{P} 2 \mathrm{Y}_{2}, \mathrm{P} 2 \mathrm{X} 4$ and $\mathrm{P} 2 \mathrm{X} 6$ receptor proteins have been immunolocalised to the TAL [375] and mRNA is expressed here for $\mathrm{P}_{2} \mathrm{Y}_{1,2,4} 4$ and 6 subtypes $[14,15,188]$.

Rat TAL segments appear poorly responsive to basolateral application of nucleotides, at least in terms of $\mathrm{Ca}^{2+}$ signalling $[14,15]$. In the mouse, however, basolateral ATP and UTP each causes large $\mathrm{Ca}^{2+}$ transients, consistent with $\mathrm{P}_{2} \mathrm{Y}_{2}$ receptor activation $[13,280]$. This work is extended with luminal application of ATP or UTP causing calcium transients in mouse medullary TAL (mTAL) perfused in vitro, an effect absent in $\mathrm{P}_{2} \mathrm{Y}_{2}$ knockout mice [174]. $\mathrm{P}_{2} \mathrm{Y}_{2}$ knockout mice have proven a useful tool for defining the role of these receptors in the kidney. These animals have increased expression of the $\mathrm{Na}^{+}-\mathrm{K}^{+}-2 \mathrm{Cl}^{-}$co-transporter and an augmented natriuretic response to furosemide [309]. These data imply that $\mathrm{P}_{2} \mathrm{Y}_{2}$ receptors exert a tonic inhibitory effect on $\mathrm{NaCl}$ transport in mouse TAL. A recent study has further indicated that activation of basolateral $\mathrm{P} 2 \mathrm{X}$ receptors triggers a marked reduction in $\mathrm{NaCl}$ absorption in mouse mTAL [237].

Further evidence directly supports a regulatory role for extracellular nucleotides on TAL function. In suspensions of rat mTAL, ATP increased intracellular NO production in a concentration-dependent manner, a response inhibited by suramin [340]. Flow-induced NO production is dependent on ATP release in TAL [41]. On the basis of agonist profiling, 
Table 1 Effects of $\mathrm{P} 2$ receptor activation in kidney segments

\begin{tabular}{|c|c|c|}
\hline Kidney segment & $\begin{array}{l}\mathrm{P} 2 \\
\text { receptor }\end{array}$ & Action \\
\hline \multirow{2}{*}{$\begin{array}{l}\text { Aldosterone-sensitive distal } \\
\text { nephron }\end{array}$} & $\mathrm{P} 2$ & Decrease $\mathrm{Na}^{+}$absorption \\
\hline & $\mathrm{P} 2 \mathrm{Y}_{2}$ & $\begin{array}{l}\text { Decrease aldosterone sensitivity } \\
\text { and } \mathrm{K}^{+} \text {excretion (with high } \mathrm{K}^{+} \text {diet) }\end{array}$ \\
\hline \multirow[t]{3}{*}{ Proximal tubule } & $\mathrm{P} 2 \mathrm{Y}_{1}$ & Increase $\left[\mathrm{Ca}^{2+}\right]_{\mathrm{i}}$, decrease bicarbonate reabsorption \\
\hline & $\mathrm{P} 2 \mathrm{Y}_{2}$ & Increase $\left[\mathrm{Ca}^{2+}\right]_{\mathrm{i}}$ and gluconeogenesis \\
\hline & $\mathrm{P}_{2} \mathrm{Y}_{6}$ & Increase $\left[\mathrm{Ca}^{2+}\right]_{\mathrm{i}}$ and inositol phosphates \\
\hline \multicolumn{3}{|l|}{ Loop of Henle } \\
\hline Thin descending limb & $\mathrm{P} 2 \mathrm{Y}_{2}$ & Increase $\left[\mathrm{Ca}^{2+}\right]_{\mathrm{i}}$ \\
\hline Thin ascending limb & $\mathrm{P} 2 \mathrm{Y}_{2}$ & Increase $\left[\mathrm{Ca}^{2+}\right]_{\mathrm{i}}$ \\
\hline Thick ascending limb & $\mathrm{P} 2 \mathrm{Y}_{2}$ & Increase $\left[\mathrm{Ca}^{2+}\right]_{i}$, decrease NKCC2 activity \\
\hline \multirow[t]{3}{*}{ Collecting ducts } & $\mathrm{P} 2$ & Decrease phosphatidylinositol bisphosphate \\
\hline & $\mathrm{P} 2 \mathrm{X} 4$ & Decrease $\mathrm{ENaC}$ activity in high $\left[\mathrm{Na}^{+}\right]$ \\
\hline & $\mathrm{P}_{2} \mathrm{Y}_{2}$ & $\begin{array}{l}\text { Increase phospholipase } \mathrm{C} \text {, decrease } \mathrm{ENaC} \\
\text { activity and } \mathrm{H}_{2} \mathrm{O} \text { reabsorption }\end{array}$ \\
\hline Cortical collecting duct & $\mathrm{P}_{2} \mathrm{Y}_{2}$ & $\begin{array}{l}\text { Increase }\left[\mathrm{Ca}^{2+}\right]_{i} \text { and phospholipase } \mathrm{C} \text {, decrease } \mathrm{ENaC} \\
\text { activity and small conductance } \mathrm{K}^{+} \text {channel }\end{array}$ \\
\hline Inner medullary collecting duct & $\mathrm{P} 2 \mathrm{Y}_{2}$ & $\begin{array}{l}\text { Increase }\left[\mathrm{Ca}^{2+}\right]_{i} \text {, prostaglandin } \mathrm{E}_{2} \text { protein kinase } \mathrm{C} \text { and } \\
\text { phospholipase } \mathrm{C} \text {, decrease endothelin-1 release, } \\
\text { cAMP and vasopressin-stimulated osmotic water } \\
\text { permeability }\end{array}$ \\
\hline
\end{tabular}

it was argued that the response was mediated primarily by P2X receptors. Further studies from the same group have defined NOS3 (eNOS) as the target for P2 receptor activation [338], in a process requiring activation of Akt1 (serine threonine kinase; aka PKB).

The physiological process coupling $\mathrm{P} 2$ receptor activation and NO production may be the flow rate of fluid thought the lumen of the TAL, which regulates nucleotide [174]. Increased flow within the physiological range has previously been shown to stimulate NO production [270] and promote translocation of NOS3 towards the apical membrane in TAL cells. Mechanistically, therefore, ATP is likely to reduce sodium flux in this segment via NO-mediated inhibition of apical transport processes and this has indeed been shown for both $\mathrm{Na}^{+}-\mathrm{K}^{+}-2 \mathrm{Cl}^{-}$co-transporter [269] and $\mathrm{Na}^{+} / \mathrm{H}^{+}$exchange activity [102]. Nevertheless, the primary effect of ATP may be reduction in basolateral $\mathrm{Na}^{+}-\mathrm{K}^{+}-$ATPase activity, since ATP reduces oxygen consumption in suspensions of TAL cells [339]. Pharmacological characterisation of this effect found it to be P2X-mediated and NOS-dependent. However, as with nucleotide-stimulated NO production, a weak inhibitory effect on oxygen consumption of UTP was found and there may be some additional $\mathrm{P} 2 \mathrm{Y}$ involvement.

\section{Distal tubules}

The distal tubule is that segment of the nephron between the macula densa and the first confluence with another tubule in the collecting duct. It is a heterogeneous segment, incorporating the distal convoluted tubule, the connecting duct and the initial portion of the cortical collecting duct (CCD). The transport properties also vary: the distal convoluted tubule is the site of thiazide-sensitive sodium reabsorption and the epithelial sodium channel is expressed in the $\mathrm{CCD}$. The connecting tubule, which is not well-defined in humans, has hybrid transport processes. P2 receptors have been identified in the native distal convoluted tubule and CCD ([13]; see [77]) and the collecting duct is discussed in detail below. However, many of the studies of distal tubule cells have been carried out on cell lines such as A6 (derived from Xenopus kidney) and Madin-Darby canine kidney (MDCK) cell. ATP activates both $\mathrm{Cl}^{-}$and $\mathrm{K}^{+}$channels in distal nephron epithelial cells from the cell line A6 by a $\mathrm{Ca}^{2+}$-dependent mechanism [243,257,315], probably via $\mathrm{P}_{2} \mathrm{Y}_{2}$ receptors $[19,250,251]$ and also in a rabbit distal convoluted tubule cell line [26]. The high-affinity $\mathrm{Ca}^{2+}$ channel of the distal tubule luminal membrane is regulated by ATP, and ATP plays a crucial role in the integrity of the cytoskeleton, which is also involved in the control of $\mathrm{Ca}^{2+}$ channels in this membrane [35,284]. Stretch-released ATP, acting through an autocrine PLC-dependent pathway, masks stretch activation of epithelial sodium channels $(\mathrm{ENaC})$ in A6 distal tubule cells [232].

Connexin hemichannels have been shown to be localised in the luminal membrane of the distal nephron and may be the mechanism underlying ATP release from these cells and play a role in the regulation of salt reabsorption [239]. Multiple P2X receptors (P2X4, P2X5 and $\mathrm{P} 2 \mathrm{X} 6$ ) have been 
immunolocalised in the distal tubule cells [411]. In particular, P2X4 and P2X6 receptors are present on the basolateral membranes of the rat distal tubule epithelium [375], and it has been claimed that P2X4-like receptors regulate ATPstimulated epithelial $\mathrm{Na}^{2+}$ channel activity in distal tubule A6 epithelium [432].

The intercalated cells of the distal nephron protrude 1$3 \mu \mathrm{m}$ further into the lumen than the principal cells; they release ATP in response to mechanical stress [136]. Extracellular nucleotides regulate $\mathrm{Na}^{+} / \mathrm{H}^{+}$exchanger isoform 3 activity in the A6-NHE3-transfected cell line; A6-NHE3 cells are A6 cells selected on the basis of high transepithelial responsiveness to aldosterone [10]. The $\mathrm{P}_{2} \mathrm{Y}_{1}$ receptor in A6 cells can increase both cAMP/PKA and $\mathrm{Ca}^{2+} / \mathrm{PKC}$ intracellular levels, and it is claimed that the PKC pathway is involved in cystic fibrosis transmembrane conductance regulator activation [120]. A6 cells were used to show that aldosterone stimulates ATP release from the basolateral side of distal tubular cells; ATP then acts via purinoceptors to produce contraction of small groups of adjacent epithelial cells, which results in apical swelling that disrupts the $\mathrm{ENaC}$ interaction with the F-actin cytoskeleton, opening the channel and hence increasing sodium transport [112]. 'Aldosterone escape' refers to the excretion of sodium during high sodium intake; local purinergic tone in the aldosterone-sensitive distal nephron downregulates $\mathrm{ENaC}$ activity. $\mathrm{P}_{2} \mathrm{Y}_{2}^{-/-}$mice had significantly less increased sodium excretion than wild-type mice [354]. It was concluded that control of $\mathrm{ENaC}$ by purinergic signalling is necessary for aldosterone escape and this was supported by another laboratory in a later paper, and in addition, it identified a potential role for $\mathrm{NO}$ and prostaglandins in response to aldosterone [434]. Mechanical stimulation of purinergic signalling leads to activation of transient receptor potential vanilloid (TRPV) 4 channels, an important component of the mechano-sensitive response of the aldosterone-sensitive distal nephron [236].

The MDCK cell line has been widely used for studies of distal tubule activities. An early paper showed that exogenous ATP stimulated ion transport in cultured MDCK cells [341]. Electrophysiological studies showed that ATP and UTP hyperpolarise MDCK cells by increasing the $\mathrm{K}^{+}$conductance [95,206]. A later paper from this group showed that ATP increased $\left[\mathrm{Ca}^{2+}\right]_{\mathrm{i}}$; calcium then activates $\mathrm{K}^{+}$channels and thus leads to hyperpolarisation of the cell membrane [281]. Regulation of transepithelial ion transport by two different receptors on the apical membrane of MDCK cells was claimed [430], the data implicating $\mathrm{P}_{2} \mathrm{Y}_{1}$ and $\mathrm{P}_{2} \mathrm{Y}_{2}$ (or $\mathrm{P}_{2} \mathrm{Y}_{4}$ ) receptors. Lanthanum inhibits UTP-induced $\mathrm{Ca}^{2+}$ mobilization in MDCK cells [164]. $\mathrm{P} 2 \mathrm{Y}_{1}, \mathrm{P}_{2} \mathrm{Y}_{2}$ and $\mathrm{P} 2 \mathrm{Y}_{11}$ receptor mRNA was shown to be expressed by MDCK cells, but the $\mathrm{P}_{2} \mathrm{Y}_{2}$ receptor was dominant in mediating ATP activation of cAMP formation [155,295,373,427]. A later paper showed expression of $\mathrm{P}_{2} \mathrm{Y}_{6}$ (as well as $\mathrm{P} 2 \mathrm{Y}_{1}, \mathrm{P}_{2} \mathrm{Y}_{2}$ and $\mathrm{P} 2 \mathrm{Y}_{11}$ ) receptors in
MDCK cells [142]. Functional P2X7 receptors are also expressed by MDCK cells [163].

Mechanical stimulation of ATP release from MDCK cells (as well as COS-7 and HEK-293 cells) occurs on changing the medium and other experimental protocols with cultured cells, leading to $\mathrm{P}_{2} \mathrm{Y}_{1}$ and $\mathrm{P} 2 \mathrm{Y}_{2}$ receptor activation [275]. Activation of $\mathrm{P} 2 \mathrm{Y}$ receptors caused strong and persistent shrinkage of MDCK renal epithelial cells [195]. The cloning and tissue expression of MDCK $\mathrm{P}_{2} \mathrm{Y}_{2}$ receptors has been reported [426]. Cyclooxygenase (COX)-2 is constitutively expressed by MDCK cells, which participates in $\mathrm{P}_{2} \mathrm{Y}_{2}$ receptor-mediated signalling [276]. Transcellular ion currents in ATP-treated MDCK cells are mainly caused by the coupled function of apical and basolateral anion transporters providing transient $\mathrm{Cl}^{-}$secretion [31]. Adenosine induces ATP release via $\mathrm{A}_{1}$ receptors in MDCK cells [244]. $\mathrm{Cl}^{-}$secretion in MDCK monolayers treated with basolateral ATP is triggered by $\mathrm{P} 2 \mathrm{Y}_{1}$ receptors and is mediated by subsequent $\left[\mathrm{Ca}^{2+}\right]_{\mathrm{i}}$-independent activation of PLA and PKA [3]. Mitochondria play an important role in adenosine-induced ATP release from MDCK cells [245]. Activation of the $\mathrm{Na}^{+}-\mathrm{K}^{+}-\mathrm{Cl}^{-}$co-transporter in MDCK cells is via $\mathrm{Ca}^{2+}$-independent signalling triggered by apical $\mathrm{P}_{2} \mathrm{Y}_{2}$ and basolateral $\mathrm{P} 2 \mathrm{Y}_{1}$ receptors [4]. Rapid pressure changes induce both apical and basolateral ATP release [299]. In a later paper, it was shown that subtle flow changes sensed by the primary cilium induced nucleotide release, which amplified the epithelial $\left[\mathrm{Ca}^{2+}\right]_{\mathrm{i}}$ response [296].

As reported earlier for proximal tubule cells, there is reversible tight junction disassembly during ATP depletion and repletion in MDCK cells [111]. MDCK epithelia spontaneously release ATP resulting in $\left[\mathrm{Ca}^{2+}\right]_{\mathrm{i}}$ oscillations leading to modifications of steady-state renal function [105]. In a later paper, it was shown that the frequency of oscillations was increased by extracellular nucleotides and was decreased if the nucleotides were removed by apyrase [380]. Betaine serves as an osmolyte that is accumulated by tubular cells to maintain osmotic balance. Acute inhibition of the betaine transport by ATP and adenosine in MDCK cells has been reported [185]. Endogenous ATP release inhibits electrogenic $\mathrm{Na}^{+}$absorption and stimulates $\mathrm{Cl}^{-}$secretion in MDCK cells [419]. Activation of c-Jun and/or p38 contributes to $\mathrm{Na}^{+}-\mathrm{K}^{+}-\mathrm{Cl}^{-}$co-transport suppression in MDCK cells by exposure to $\mathrm{P}_{2} \mathrm{Y}_{1}$ agonists [5]. The proto-oncoprotein SYT(SS18) controls ATP release and regulates cyst formation by polarised MDCK cells, suggesting that SYT plays a vital role in controlling epithelial morphogenesis and might explain the lethality of its loss in the developing embryo [56]. P2 receptormediated inhibition of vasopressin (AVP)-stimulated fluid transport and cAMP response in AQP2-transfected MDCK cell has been reported [186].

Adenosine modulates $\mathrm{Mg}^{2+}$ uptake in distal convoluted tubule cells via $A_{1}$ and $A_{2}$ receptors [181] and a volumesensitive-like chloride conductance in a rabbit distal convoluted tubule cell line (DC1) [316]. Both basolateral and apical 
$A_{1}$ receptors were shown to mediate sodium transport in cultured A6 cells [234].

\section{Collecting ducts}

A large number of $\mathrm{P} 2 \mathrm{X}$ and $\mathrm{P} 2 \mathrm{Y}$ receptor subtypes have been localised to the rat collecting duct. Immunohistochemistry has identified the expression of P2X1 (intercalated cells only, sodium-restricted only) $\mathrm{P} 2 \mathrm{X} 2,4,5$ and 6 subunits and $\mathrm{P} 2 \mathrm{Y}_{2}$, 4, 6, 11, 12 and 13 subtypes [188,375,409]. These immunohistochemical data have largely been validated by mRNA expression profiles in the rat tubule. $\mathrm{P} 2 \mathrm{Y}_{1,2,4}$ and 6 metabotropic and $\mathrm{P} 2 \mathrm{X} 4$ ionotropic receptor mRNAs were identified in the cortical and outer medullary collecting duct [13,15,409], with $\mathrm{P} 2 \mathrm{X} 1$ and 6 receptor mRNAs also reported following dietary sodium restriction [409]. mRNA for $\mathrm{P}_{2} \mathrm{Y}_{1,2,4}$ and 6 subtypes was identified in the inner medullary collecting duct (IMCD) [188,433]. P2X1, 4, 5, 6 and 7 mRNAs have been localised to the murine cortical and outer medullary collecting duct, indicative of species differences in expression profiles [219]. In humans, only P2X4 has been detected in significant amounts in the collecting duct [50]. Activation of P2X receptors increased both sodium and water excretion [168]. Hypotonic treatment evokes biphasic ATP release across the basolateral membrane of cultured A6 cells [106,172].

Although the functional role of $\mathrm{P} 2$ receptors in the collecting duct is complex, several studies, using a combination of approaches, have demonstrated that extracellular nucleotides modulate water and electrolyte handling in this region of the nephron. These effects are important for sodium and water homeostasis since it is in this section of the nephron that urinary excretion is fine-tuned to meet the body's overall requirements.

\section{Water transport}

The regulation of urine concentration and water homeostasis occurs in the collecting duct, under the control of AVP released from the brain. AVP increases the water permeability of the collecting duct by evoking the translocation to the apical membrane of the aquaporin 2 water channel (AQP2): this requires phosphorylation of $\mathrm{AQP} 2$ by $\mathrm{PKA}$. In addition to these rapid, non-genomic effects, chronic AVP stimulation increases the water permeability of the collecting duct through the increased transcription of the AQP2 gene. Several studies have demonstrated that nucleotides have an inhibitory affect on the action of AVP in the collecting duct.

The ability of ATP to modulate AVP-induced water permeability in the collecting duct was first demonstrated in the mid-1990s. ATP was shown to reversibly inhibit AVPs' actions in isolated perfused rabbit $\mathrm{CCD}$ and rat IMCD [187,188,314]. Since UTP and ATP were equipotent, the inhibitory effects were attributed to the activation of $\mathrm{P} 2 \mathrm{Y}_{2}$
[188]. $P 2 Y_{2}$ couples to the G-protein $G_{q}$, and as such, its stimulation causes the activation of PLC, increased inositol trisphosphate production and consequently the mobilization of $\left[\mathrm{Ca}^{2+}\right]_{\mathrm{i}}$. Both ATP and UTP stimulated intracellular calcium release in rat IMCD [74], and inhibition of calcium mobilization attenuated ATP's effects in isolated rabbit CCD [314]. Notably, adenylate cyclase, stimulated by AVP and PLC, stimulated by ATP, are mutually inhibitory pathways. PLC activates PKC, which inhibits adenylate cyclase [369]. Indeed the inhibitory effects of $\mathrm{P} 2 \mathrm{Y}_{2}$ receptors have been shown to be associated with PKC-dependent reductions in cAMP [187]. More recently, COX-1-mediated prostaglandin (PG) $\mathrm{E}_{2}$ synthesis has also been implicated in ATPs' inhibitory effects. ATP $\gamma \mathrm{S}$ stimulation of IMCD fractions from hydrated rats resulted in increased $\mathrm{PGE}_{2}$ synthesis $[357,401]$, an effect that was blunted in IMCD fractions from dehydrated rats [357]. Furthermore, enhanced $\mathrm{P}_{2} \mathrm{Y}_{2}$ abundance (mRNA and protein) was documented in hydrated rats and was associated with increased $\mathrm{PGE}_{2}$ [191]. Since $\mathrm{PGE}_{2}$ decreases the water permeability of the collecting duct, these data add support to the concept that cross-talk between AVP and ATP provides an additional level of hydrosmotic regulation. Indeed, chronic stimulation of V2R with ddAVP, as would occur during dehydration, reduced $\mathrm{P} 2 \mathrm{Y}_{2}$ abundance in rats [357]. However, the interaction between AVP and ATP may vary in the short and long term. In isolated perfused CCD, acute AVP exposure stimulated nucleotide secretion [264]. A recent paper has shown that ATP counteracts AVP-induced water permeability by increasing AQP2 degradation in lysosomes, preceded by ubiquitin internalization and by decreasing AQP2 gene transcription by reducing AVP-induced cAMP levels [29].

$\mathrm{P}_{2} \mathrm{Y}_{2}$ is located on both the apical and basolateral membranes of the collecting duct [188]; however, the demonstration that luminal ATP did not alter AVP-stimulated water permeability in isolated rat IMCD suggested that its effects are mediated by activation of $\mathrm{P} 2 \mathrm{Y}_{2}$ receptors on the basolateral membrane [76]. Recent studies in immortalised mouse collecting duct cells (mpkCCDc14) have provided a possible mechanism for ATP's inhibitory effect on water transport. Whereas ddAVP application resulted in increased AQP2 immunofluorescence at the apical membrane, ATP and $\mathrm{ATP} \gamma \mathrm{S}$ resulted in $\mathrm{AQP} 2$ internalisation. In addition to basolateral $\mathrm{P} 2 \mathrm{Y}_{2}$ receptors, luminal $\mathrm{P} 2 \mathrm{X} 2$ and $\mathrm{P} 2 \mathrm{Y}_{4}$ stimulation may also be involved in ATP's inhibitory effects. Coexpression of these receptors with AQP2 in Xenopus oocytes resulted in decreased membrane expression of AQP2 and, consequently, attenuated water permeability [415].

Gene deletion studies have substantiated the findings from the pharmacological manipulation. $\mathrm{P}_{2} \mathrm{Y}_{2}{ }^{-1-}$ mice have increased medullary AQP2 expression and greater basal collecting duct fluid reabsorption than wild-type controls. These data suggest that $\mathrm{P} 2 \mathrm{Y}_{2}$ stimulation provides a tonic inhibition of AVP actions at $\mathrm{V}_{2}$ receptors [309,382,433]. 


\section{Sodium transport}

The effects of extracellular nucleotides on sodium reabsorption in the collecting duct have largely been discerned through the evaluation of amiloride or benzamil-sensitive sodium transport, taken to reflect the activity of the epithelial sodium channel. Koster et al. [197] made the first demonstration that activation of $\mathrm{P} 2$ receptors inhibited benzamil-sensitive sodium transport. Using cultured rabbit collecting duct cells, they showed that both apically and basolaterally applied ATP inhibited benzamil-sensitive short circuit currents (an indicator of sodium transport). The inhibition of $\mathrm{Na}^{+}$transport was dependent on PKC but not $\mathrm{Ca}^{2+}$ signalling. Since ATP and UTP were equipotent, and ADP had no effect, inhibition of $\mathrm{ENaC}$-mediated sodium transport was attributed to activation of $\mathrm{P}_{2} \mathrm{Y}_{2}$ [197]. Subsequently, studies in the M-1 mouse collecting duct cell line demonstrated that amiloridesensitive sodium reabsorption was reduced by both the apical and basolateral application of ATP and UTP. Since ADP and UDP had no effect, these results were consistent with the activation of $\mathrm{P}_{2} \mathrm{Y}_{2}$. Indeed, the presence of $\mathrm{P}_{2} \mathrm{Y}_{2}$ receptors in the cell line was confirmed by RT-PCR [63]. However, in contrast to the data from cultured rabbit collecting duct cells, the effects of ATP were not dependent on PKC activation [370]. In a different model, mIMCD-K2 mouse collecting duct cells, apical (but not basolateral) nucleotides inhibited sodium reabsorption, an effect, which based on mRNA expression and pharmacological profiling, was attributed to activation of $\mathrm{P} 2 \mathrm{Y}_{1}, \mathrm{P}_{2} \mathrm{Y}_{2}, \mathrm{P} 2 \mathrm{X} 3$ and $\mathrm{P} 2 \mathrm{X} 4$ receptors [238]. More recently, studies in the mouse IMCD cell line (mIMCD3) provided a possible mechanism for nucleotide-mediated $\mathrm{ENaC}$ inhibition. Extracellular nucleotides caused a reduction in serum- and glucocorticoid-inducible kinase-1 (SGK1) expression and activity. Since SGK promotes the insertion of $\mathrm{ENaC}$ into the apical membrane, it was postulated that nucleotides modulate sodium reabsorption through the regulation of SGK1 and, consequently, ENaC activity [220]. In addition, local phosphoinositide levels may modulate basal and acute ENaC activity. In immortalised mouse CCD cells, (mpkCCDe14), phosphatidylinositol 4,5-bisphosphate (PI(4, 5)P2) concentrations correlated with $\mathrm{ENaC}$ activity. Given that the inhibition of both purinergic signalling and PLC rescued $\mathrm{ENaC}$ activity, it was postulated that purinergic regulation of $\mathrm{PI}(4,5) \mathrm{P} 2$ concentrations, through the activation of $\mathrm{P} 2 \mathrm{Y}$ receptors, modulates $\mathrm{ENaC}$ activity [288]. $\mathrm{ENaC}$ in the aldosterone-sensitive distal nephron is under tonic inhibition by local purinergic signalling responding to changes in dietary sodium intake [37]. Table 2 summarises $\mathrm{P} 2$ receptor actions on $\mathrm{ECaC}$ activity.

In addition to the inhibition of sodium reabsorption, ATP stimulation also increases $\mathrm{Cl}^{-}$secretion. In mIMCD3 cells, ATP stimulates $\mathrm{Cl}^{-}$conductance by a calciumdependent mechanism [352]. Extracellular ATP-induced calcium signalling requires both $\mathrm{P} 2 \mathrm{X}$ and $\mathrm{P} 2 \mathrm{Y}$ receptors in mIMCD-3 cells [417]. The TRPC3 is exclusively expressed in the apical membrane of principal cells of the collecting duct, both in vivo and in the MIMCD cell line. It has been shown that mIMCD-3 cells have two distinct calcium influx pathways: a store-operated channel activated by thapsigargin and basolateral ATP and TRPC3 channels activated by apical ATP [108]. Adenosine, acting on $\mathrm{A}_{2 \mathrm{~B}}$ receptors, also enhances $\mathrm{Cl}^{-}$secretion through cystic fibrosis transmembrane conductance regulator (CFTR) in IMCD-K2 cells [302]. The authors proposed that the adenosine receptor pathways might provide one mechanism for enhancing urine $\mathrm{NaCl}$ excretion in the setting of high dietary $\mathrm{NaCl}$ intake. It was later proposed that $\mathrm{P}_{2} \mathrm{Y}_{1}$ and $\mathrm{P} 2 \mathrm{Y}_{2}$ receptors operate in tandem in IMCD cells to enhance urinary $\mathrm{NaCl}$ excretion in these conditions [303]. A recent whole kidney study showed that in rats on high sodium intake, adenosine had the potential to enhance renal excretion [201].

Table 2 A summary of the effects of P2 receptor activation on ENaC activity (reproduced from [414], with permission from Springer)

\begin{tabular}{|c|c|c|c|c|c|}
\hline Epithelia & Species & $\mathrm{P} 2$ receptor involved (localisation) & Effect on $I_{\text {am-s }}$ & Mechanism & Reference \\
\hline $\mathrm{CCD}$ & Mouse & $\mathrm{P}_{2} \mathrm{Y}_{2}$ (ap., baso.) & Inhibits & - & [214] \\
\hline $\mathrm{CD}$ & Rat & P2X4-like (ap.) & Inhibits & - & [332] \\
\hline \multirow[t]{2}{*}{$\mathrm{CCD} / \mathrm{OMCD}$} & \multirow[t]{2}{*}{ Rat } & $\mathrm{P}_{2} \mathrm{Y}_{2} / \mathrm{P}_{2} \mathrm{Y}_{4}$ (ap.) & Inhibits & $\mathrm{PKC}$ & [413] \\
\hline & & $\mathrm{P} 2 \mathrm{X} 4 / \mathrm{P} 2 \mathrm{X} 4 / 6$ (ap.) & Inhibits or potentiates & ? or PI3K & [413] \\
\hline M1 cell line & Mouse & $\mathrm{P}_{2} \mathrm{Y}_{2}$ (ap., baso.) & Inhibits & $\uparrow\left[\mathrm{H}^{+}\right]_{\mathrm{int}}$ & {$[63,370]$} \\
\hline \multirow[t]{2}{*}{ A6 cell line } & \multirow[t]{2}{*}{ Xenopus } & $\mathrm{P} 2 \mathrm{Y}_{2}$ (ap.) & Inhibits & PLC $, \downarrow \mathrm{PIP}_{2}, \downarrow$ open prob. & [232] \\
\hline & & P2X4-like (baso.) & Potentiates & PI3K, $\uparrow$ open prob. & [432] \\
\hline $\mathrm{CCD} 1^{\circ}$ cultures & Rabbit & P2Y $\mathrm{Y}_{2}$-like (ap., baso.) & Inhibits & PLC, PKC & {$[197]$} \\
\hline mIMCD-K2 cell line & Mouse & $\mathrm{P} 2 \mathrm{X} 3, \mathrm{P} 2 \mathrm{X} 4, \mathrm{P}_{2} \mathrm{Y}_{1}, \mathrm{P}_{2} \mathrm{Y}_{2}$ (ap.) & Inhibits & - & [238] \\
\hline
\end{tabular}

$I_{a m-s}$ amiloride-sensitive current (i.e. ENaC-mediated current), ap. apical membrane, baso. basolateral membrane, $\uparrow$ increase, $\downarrow$ decrease, $P K C$ protein kinase C, $P L C$ phospholipase C, $P I 3 K$ phosphoinositide 3-kinase, $P I P 2$ phosphatidylinositol bisphosphate, $M A P K$ mitogen-activated protein kinase, $1^{\circ}$ primary cell cultures, open prob. single channel opening probability, $C C D$ cortical collecting duct, $O M C D$ outer medullary collecting duct 
Further to the results from cell culture, nucleotide-induced inhibition of sodium transport has also been demonstrated in native collecting duct tissue. In isolated perfused mouse collecting ducts, the application of luminal ATP and UTP caused increased calcium release [67] and inhibition of amiloridesensitive sodium transport [214], effects which were attributed to the stimulation of $\mathrm{P} 2 \mathrm{Y}_{2}$ receptors. Consistent with $\mathrm{P} 2 \mathrm{Y}_{2}$ receptors being the primary mediator of nucleotide-induced inhibition of ENaC, ATP's effects on sodium reabsorption were significantly reduced in collecting duct cells isolated from $\mathrm{P}_{2} \mathrm{Y}_{2}{ }^{-1}$ receptor mice. However, residual ATP effects implicated the involvement of other $\mathrm{P} 2$ receptors [289]. Recently, $\mathrm{P}_{2} \mathrm{Y}_{2}$ receptor activation has been shown to increase renal $\mathrm{Na}^{+}$excretion and decrease blood pressure [310].

Shirley et al. [332] provided the first in vivo evidence that P2 receptors on the apical membrane of the collecting duct inhibit sodium reabsorption. Rats were maintained on a low sodium diet to induce $\mathrm{ENaC}$ expression and urinary recovery of ${ }^{22} \mathrm{Na}$ during microperfusion of the late distal nephron used to assess sodium reabsorption. Notably, despite the firm evidence from in vitro studies in mice showing $\mathrm{P}_{2} \mathrm{Y}_{2}$-mediated inhibition of sodium reabsorption in the collecting duct, $\mathrm{P}_{2} \mathrm{Y}_{2} /$ $\mathrm{P}^{2} \mathrm{Y}_{4}$ 'selective' agonists had no effect in the rat preparation, and the involvement of a P2X heteromer was hypothesised [332]. More recently, patch-clamp studies in split open rat CCDs have demonstrated the involvement of both apical $\mathrm{P} 2 \mathrm{X}$ and $\mathrm{P} 2 \mathrm{Y}$ receptors in the modulation of $\mathrm{ENaC}$ activity. Activation of $\mathrm{P}_{2} \mathrm{Y}_{2}$ and $\mathrm{P}_{2} \mathrm{Y}_{4}$ receptors resulted in PLCdependent inhibition of ENaC activity. Interestingly, activation of $\mathrm{P} 2 \mathrm{X} 4$ and $\mathrm{P} 2 \mathrm{X} 4 / 6$ receptors caused an inhibition of
$\mathrm{ENaC}$ activity when luminal concentrations of sodium were high (145 mM); however, when sodium concentrations were reduced to more physiological levels $(50 \mathrm{mM})$, activation of the receptors potentiated $\mathrm{ENaC}$ activity $[412,413]$. In accordance with a $\mathrm{P} 2 \mathrm{X} 4$ component to purinergic regulation of sodium transport is the demonstration that in the 'distal-like' cell line, Xenopus A6 cells, activation of basolateral P2X4like receptors resulted in increased apical membrane insertion of $\mathrm{ENaC}$. These data suggest that there is reciprocal purinergic signalling for the control of sodium transport by both apical and basolateral purinoceptors ([432]; see Fig. 5). These data highlight the complex relationship between apical and basolateral $\mathrm{P} 2$ receptors in the modulation of sodium transport in the collecting duct.

An additional layer of complexity was unveiled with the demonstration that sympathetic nerve varicosities are in close apposition to basolateral membranes of collecting duct epithelial cells of the rat kidney [230]. It was suggested that while luminal responses to autocrine or paracrine release of ATP from epithelial cells may dominate in normal physiological conditions, in pathological states, such as stress and dehydration, ATP released as a cotransmitter from sympathetic nerves may be involved in modulating collecting duct fluid and electrolyte transport via basolateral purinoceptors. It is interesting that in a recent paper, it was shown that chronic renal sympathetic denervation increased the renal tubular natriuretic and diuretic actions of ATP mediated by P2X receptors [199].

Gene deletion studies have focused on sodium homeostasis in $\mathrm{P}_{2} \mathrm{Y}_{2}$ null mice. Mice lacking $\mathrm{P}_{2} \mathrm{Y}_{2}$ receptors have hypertension and facilitated sodium and water reabsorption of the aldosterone-

\section{a $5 \mathrm{~min}$}

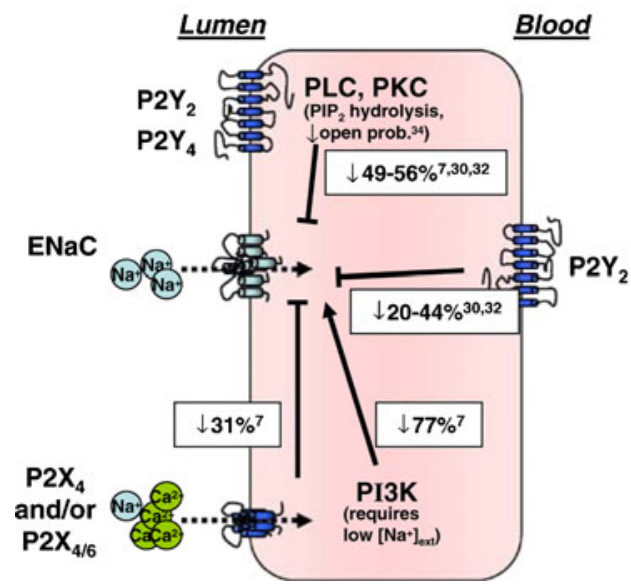

Fig. 5 A summary of known effects of $\mathrm{P} 2$ receptor (P2R) activation on $\mathrm{ENaC}$ activity taken from experiments using renal principal cells (PCs) or distal nephron-derived cell lines. Relevant references are superscripted. In a, effects where $5 \mathrm{~min}$ or less are left between P2R activation and measurements of ENaC activity. All but apical P2X4/6 activation decreases the activity of ENaC. Apical P2X4/6 has the ability to inhibit or potentiate $\mathrm{ENaC}$ activity depending on the concentration of luminal $\mathrm{Na}^{+}$. Noteworthy is that basolaterally expressed $\mathrm{P} 2 \mathrm{X} 4$ receptors have not been

\section{b $\quad 15-30 \mathrm{~min}$}

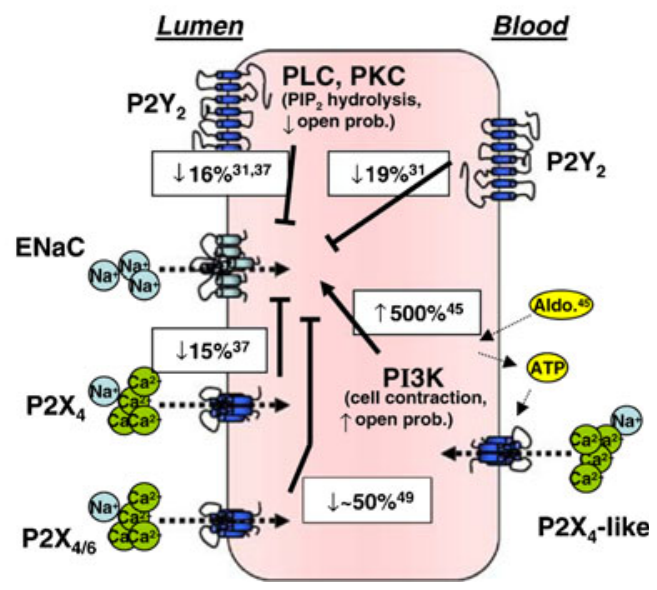

reported to affect $\mathrm{ENaC}$ activity. In $\mathbf{b}$, effects where 15-30 min are left between P2R activation and measurement of ENaC activity. All apically expressed P2Rs inhibit ENaC, although the ability of $\mathrm{P} 2 \mathrm{Y}$ receptors to inhibit $\mathrm{ENaC}$ is less than that in a (from 49-56 to $16 \%$ ). The potentiating effect of apical P2X4/6 receptors (when luminal $\mathrm{Na}^{+}$is low) has not been investigated over a 30 -min period, but a potentiating effect of basolaterally expressed $\mathrm{P} 2 \mathrm{X} 4$-like receptors has been reported (reproduced from [414], with permission from Springer) 
sensitive distal nephron [309]. Resting ENaC activity was greater in $\mathrm{P} 2 \mathrm{Y}_{2}{ }^{-1-}$ receptor mice than controls suggesting that local ATP may be involved in the regulation of basal ENaC activity in the murine collecting duct [289,290]. Additional studies from the same laboratory demonstrated that $\mathrm{ENaC}$ downregulation in response to sodium restriction was lost in the $\mathrm{P} 2 \mathrm{Y}_{2}$ null mice, suggesting a role for the receptor in the renal response to altered sodium intake [291]. Despite this, the hypertension was not saltsensitive, suggesting that these renal changes are compensated for elsewhere.

Extracellular ATP in the CCD not only inhibits ENaC, but also stimulates calcium-activated chloride channels (CACC). It has been shown that ATP stimulates CACC-mediated $\mathrm{Cl}^{-}$adsorption during aldosterone stimulation, and it was suggested that an interplay between purinergic signalling pathways and aldosterone may be involved in regulation of $\mathrm{NaCl}$ transport in $\mathrm{CCD}$ cells under different states of extracellular fluid volume [304].

\section{Release and metabolism of nucleotides}

Release of nucleotides from renal cells was originally suggested from studies of cell lines [328,329,387]; it is now clear that native renal tubules are also able to secrete ATP. Nucleotide release from renal epithelia is both constitutive (suggestive of a 'purinergic tone') and activated by mechanical or agonistinduced stimuli. Microelectrodes have measured steady-state ATP concentrations of $\sim 400 \mathrm{nM}$ in the rat kidney cortex and showed that infusion of Ang II caused a rapid and transient increase, consistent with regulated release of nucleotide [277].

In vivo micropuncture experiments indicate that luminal ATP in the PCT is 200-300 nmol/1, higher than concentrations in the glomerular filtrate [388], consistent of release into the urine from epithelial cells. In contrast, concentrations in distal tubule fluid were approximately $30 \mathrm{nmol} / 1$.

In isolated perfused mouse TAL, spontaneous oscillations in $\left[\mathrm{Ca}^{2+}\right]_{\mathrm{i}}$ were dependent on tubular nucleotide release [105]. Furthermore, flow-induced elevations of $\mathrm{Ca}^{2+}$ transients were also dependent on nucleotide release, being blocked by application of an ATP scavenger or the P2 receptor blocker suramin [174]. Agonist-induced nucleotide release has also been demonstrated in the TAL, with intraluminal AVP causing intraluminal nucleotide concentrations to rise to $200-300 \mathrm{nmol} / 1$ [264]. This study also showed that AVP could trigger nucleotide secretion from the mouse CCD: intraluminal ATP/UTP concentrations again reached values approaching $300 \mathrm{nmol} / \mathrm{l}$.

It is open to debate whether the nucleotide concentrations measured intraluminally in the above studies reflect those in

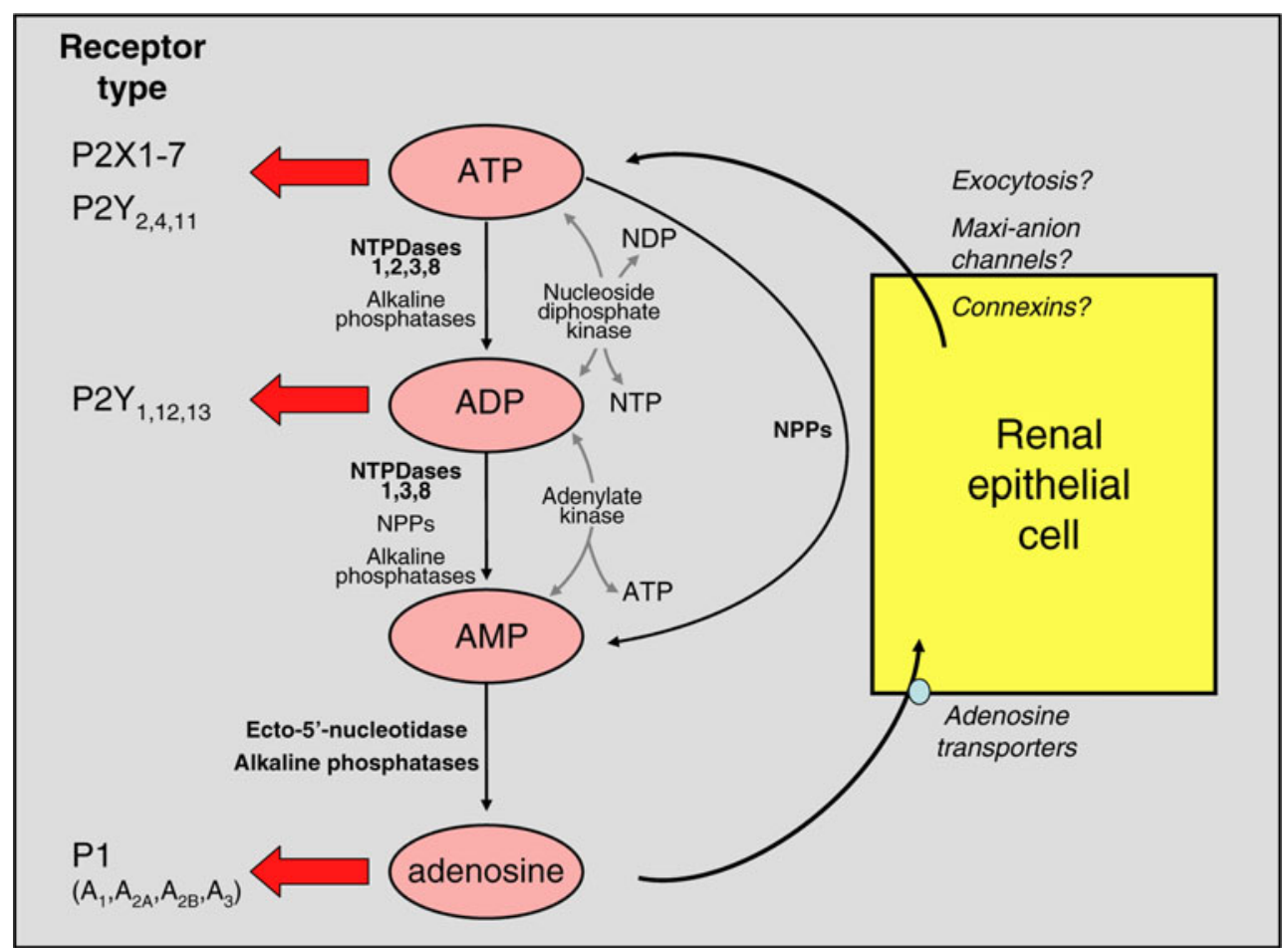

Fig. 6 Potential effects of renal ectonucleotidases and consequences for activation of purinoceptor subtypes. The major enzymes involved in each degradative pathway are shown in bold print; for more details, see text. The information given in the figure indicates the relative potencies of ATP and ADP with respect to $\mathrm{P} 2 \mathrm{X}$ and $\mathrm{P} 2 \mathrm{Y}$ receptor subtypes. At sufficiently high concentrations, ATP can activate all $\mathrm{P} 2$ receptors other than $\mathrm{P}^{2} \mathrm{Y}_{6}$ and $\mathrm{P}_{2} \mathrm{Y}_{14}$. It is important to note that nucleotides derived from other bases are also hydrolysed/synthesised by these enzymes, but have been omitted for clarity. Uracil-based nucleotides are particularly significant: UTP is a potent agonist of $\mathrm{P}_{2} \mathrm{Y}_{2}$ and $\mathrm{P}_{2} \mathrm{Y}_{4}$ subtypes, and its dinucleotide derivative UDP is the major naturally occurring agonist of the $\mathrm{P}_{2} \mathrm{Y}_{6}$ subtype. The mechanism(s) of ATP exit from renal cells has/have not been defined. NDP nucleoside diphosphate, NTP nucleoside triphosphate (reproduced from [333], with permission from Springer) 
the vicinity of the P2 receptors in the cell membrane. Membrane-bound and soluble ectonucleotidases (vide infra) will rapidly metabolize secreted nucleotides, and it has been estimated that bulk-phase measurements could underestimate concentrations at the cell membrane by more than 20 -fold, at least in astrocytes [179]. Figure 6 summarises the distribution of ecto-nucleotidases along the nephron.

Flow-induced nucleotide release

In renal cells, a primary cilium protrudes into the tubule lumen and responds to changes in flow by bending and increasing $\left[\mathrm{Ca}^{2+}\right]_{\mathrm{i}}[299]$. MDCK cells, which have properties of cells in the collecting duct, are ciliated and release ATP in response to increased flow [297]. Removal of the cilium or application of apyrase or suramin to the apical membrane prevented flowinduced nucleotide release.

TRPV4 channels are critical to flow-induced nucleotide release. In isolated thick ascending limbs, ATP secretion is substantially reduced following blockade or siRNA knockdown of TRPV4 [337]. Similar data were obtained in MDCK cells [198], and here TRPV4 colocalises in cilia with polycystin 2. Polycystin 2 is an ion channel devoid of intrinsic mechanosensitive properties but forms with TRPV4 in the cilium base a complex allowing $\mathrm{Ca}^{2+}$ influx when the cilium is bent. This triggers the release of nucleotides and autocrine/ paracrine activation of $\mathrm{P} 2$ receptors [297].

\section{Mechanism of nucleotide release}

The exit route for secretion of nucleotide is not yet resolved: several pathways may contribute and this may differ from segment to segment. Exocytosis of vesicles containing ATP is well established in neurones, and a similar mechanism is observed in cell lines of proximal tubular origin [387]. A variety of channels/transporters may also contribute to nucleotide release. In the macula densa, for example, ATP transport across the basolateral membrane is mediated by maxi-anion channels [22] and contributes to tubuloglomerular feedback (see above). CFTR channels may also mediate ATP release in the kidney [348], but this has not received firm support [296].

More recently, connexin hemichannels have emerged as a route for ATP release from renal cells. Connexins are transmembrane proteins and several members of the family are expressed in the renal vasculature and tubules [123]. The homo- or heteromeric assembly of six connexins forms a connexon: two connexons from neighbouring cells can dock to form a gap junction. Undocked connexons may also function as transmembrane hemichannels and these contribute to cellular ATP secretion [60]. Evidence from Cx30 null mice suggests a similar role in the distal nephron [342]. In wild-type mice, increases in tubular flow or reductions in osmolarity of the bathing solution caused increases in ATP concentration to
10-50 $\mu \mathrm{mol} / 1:$ these responses were almost absent in $\mathrm{Cx} 30$ knockout mice.

Although intriguing, these data must be assessed cautiously since connexin hemichannels appear to open only under nonphysiological conditions [297]. In contrast, pannexins, structurally homologous to connexins [317], are permeable to ATP and can be activated by membrane depolarisations in the physiological range [229]. It now seems likely that pannexin- 1 hemichannels mediate ATP release from epithelial cells involved in water and sodium reabsorption [124].

\section{Metabolism by ectonucleotidases}

Extracellular nucleotides are rapidly degraded to other nucleotides or nucleosides by surface-located and soluble enzymes (ectonucleotidases). Four families of ectonucleotidases exist: ectonucleoside triphosphate diphosphohydrolases (NTPDases), ectonucleotide pyrophosphatase phosphodiesterases (NPPs), ecto-5'-nucleotidase and alkaline phosphatises, and all are found in the kidney [333]. These enzymes play an important part in renal nucleotide signalling. They will control the availability of nucleotides agonists by hydrolysis and also dictate the signalling environment via generation of nucleotides or nucleosides that preferentially target different $\mathrm{P} 2 / \mathrm{P} 1$ receptor subtypes.

The NTPDase family comprises eight members of which four (NTPDases 1, 2, 3 and 8) hydrolyse extracellular nucleotides. NTPDase1 hydrolyses ATP and ADP with almost equal preference, whereas NTPDase2 has a much greater preference for ATP, therefore causing accumulation of ADP; NTPDases 3 and 8 are intermediate in their preference [333]. These differential preferences for hydrolysis are functionally significant. For example, the presence of NTPDase1 will abruptly terminate all P2 receptor stimulation, whereas if NTPDase 2 is expressed alone, the conversion of ATP to ADP would potentiate $\mathrm{P}_{2} \mathrm{Y}_{1}, \mathrm{P} 2 \mathrm{Y}_{12}$ and $\mathrm{P} 2 \mathrm{Y}_{13}$ receptor activation [382].

NTPDase1 is prominent throughout most of the renal vasculature and evident in the thin ascending limb of Henle and medullary CD [190,389]. NTPDase2 has been immunolocalised to Bowman's capsules and to most nephron segments beyond the proximal tubule [190,389]. NTPDase3 has a similar distribution to NTPDase2 [389], whereas information on NTPDase8 is incomplete.

The NPP family comprises seven members, but only NPPs 1-3 are able to hydrolyse nucleotides. NPPs can hydrolyse ATP and ADP to AMP. Information on the intrarenal distribution of NPPs is limited. NPP1 protein is expressed in proximal tubules and in basolateral membranes of distal tubules [126]. NPP3 is localised to rat glomeruli and the proximal straight tubule but is absent in distal nephron segments [389].

Ecto-5'-nucleotidase catalyses the final stage of nucleotide hydrolysis to nucleoside and is highly expressed in the kidney; 
it is found in apical membranes of rat PCT and in intercalated cells throughout the distal nephron, as well as the peritubular space $[98,207,389]$.

The physiological role of these enzymes is not clear and experimental evidence is limited. Nevertheless, NTPDase 1 in the vasculature prevents ADP-induced platelet aggregation [81] and may also terminate P2X1-mediated vasoconstriction in response to ATP. In the glomerulus, NTPDase1 and NPP3 could influence the ultrafiltration coefficient by controlling P2 signalling in mesangial cells [166].

\section{Renal pathophysiology}

Renal injury and failure

It has been proposed that adenosine mediates haemodynamic changes in adult renal failure [57,344]. In human renal cortex, sympathetic nerve stimulation releases ATP and NA, and NA acting on non-neuronal cells also releases ATP. The released ATP has mitogenic effects on glomerular epithelial cells, probably via $\mathrm{P}_{2} \mathrm{Y}_{1}$ receptors, and ATP has the potential to contribute to remodelling of the kidney and progression to chronic renal failure, a condition that presents with sympathetic overactivity [391]. While P2X7 receptors are only weakly expressed in healthy glomerulus, following glomerular injury (for example, in diabetes and hypertension), it is significantly upregulated, mainly in podocytes, but also in endothelial and mesangial cells [393]. P2X7 receptors have been shown to participate in disturbed intracellular calcium homeostasis in peripheral blood mononuclear cells of patients with chronic kidney disease [205]. Cyclosporine has become a standard component of the immunosuppressive regime in both solid organ and bone marrow transplantation as well as for the treatment of autoimmune diseases. However, a limiting factor in its use has been the development of nephrotoxicity and hypertension in many patients. Using the adriamycin nephropathy mouse model of chronic renal injury, regulatory $\mathrm{T}$ cells were shown to participate in CD39-mediated protection from renal injury [397]. A $\mathrm{K}_{\text {atp }}$ channel opener, nicorandil, reduces chronic renal injury by targeting podocytes and macrophages [365].

Primary idiopathic nephrotic syndrome is a source of morbidity in children; in some cases, mutations in podocyte genes explain the proteinuria, although it has been proposed that the condition is linked to $\mathrm{T}$ cell immunity. It has been claimed that ATP plays a key role in the regulation of innate immunity in this disease, and the effects of adenosine are reduced by the decreased expression of ectonucleotidase in this syndrome [24].

A mechanism has been proposed linking renal tubular epithelial cell death and injury to renal interstitial peritubular fibroblasts, which suggests that $\mathrm{P} 2 \mathrm{X} 7$ receptors mediate deleterious renal epithelial-fibroblast cross-talk [293]. In another paper from this group, it was shown that necrotic renal proximal epithelial cells stimulated the expression of $\mathrm{P} 2 \mathrm{X} 7$ receptors in renal interstitial fibroblasts through activation of the ERK signalling pathway [294]. It has been suggested that P2X7 receptor antagonists could offer innovative preventive and therapeutic modalities for the treatment of morbidity and mortality associated with kidney injury [429]. ATP binding enhanced the activity of $\mathrm{ClC}-5$, the transporter mutated in Dent disease, a disease affecting the renal proximal tubule [405]. Arterial calcification is prevalent in patients with chronic kidney disease and ATP signalling appears to be involved (see review by [90]).

It has been reported that $\mathrm{A}_{2 \mathrm{~B}}$ receptor-mediated induction of interleukin (IL)- 6 contributes to renal fibrogenesis, and the authors suggested that this receptor may have therapeutic potential for treatment of chronic kidney disease [65]. $A_{2 B}$ receptor activation protects against acute kidney injury via inhibition of neutrophil-dependent release of tumour necrosis factor- $\alpha$ [116]. Dendritic cells activated by $\mathrm{A}_{2 \mathrm{~A}}$ receptor agonists attenuate acute renal injury [221]. A review describing adenosine generation and signalling during acute kidney injury is available [20].

\section{Polycystic kidney disease}

PKD is a genetic disorder associated with abnormal proliferation of tubular cells of the adult nephron [53]. This leads to progressive dilation of tubules, which eventually become encapsulated in fluid-filled cysts that compress and destroy neighbouring tissue. ATP is released and reaches high concentrations within cysts $[329,416]$. Autosomal dominant polycystic disease (ADPKD) is characterised by bilateral cyst formation in the kidneys. It is a genetic disease caused by the mutation of either PKD1 or PKD2, which encodes for polycystin. Polycystin-2 is localised to the cilia of mouse and human vascular endothelial cells, which sense fluid flow via purinergic receptor activation and NO release, but in ADPKD patients, it is absent [1]. The authors suggest that aberrant expression of polycistin-2 in cilia could promote high blood pressure because of inability to synthesise NO in response to shear stress produced by changes in blood flow. Expression of polycistin-1 enhances endoplasmic reticulum calcium uptake and decreases capacitative calcium entry in ATP-stimulated MDCK cells [137]. The nematode Caenorhabditis elegans has been used as an animal model for studying basic molecular mechanisms underlying human ADPKD; the C. elegans LOV-1 and PKD-2 proteins are homologues of human PC-1 and $\mathrm{PC}-2$ proteins. Using this model, it was claimed that ciliary localised ATP synthase may play a role in polycystin signalling [141]. The involvement of nucleotide release in both fluid flow and pressure responses and its role in altered mechanosensory transduction in the aetiology of PKD is discussed in a recent review [279]. Using collecting duct principal cells derived from the Oak Ridge polycystic kidney 
mouse model of ARPKD, it was shown that the loss of apical monocilia impairs flow-induced ATP secretion across the apical cell surface and ATP-induced calcium signals [140].

P2X7 receptors were shown to be expressed in collecting duct cysts in the $c p k / c p k$ mouse model of congenital PKD [132], where it mediates cyst development [133]. In a later paper from this group $\mathrm{P}_{2} \mathrm{Y}_{1}, \mathrm{P}_{2} \mathrm{Y}_{2}, \mathrm{P}_{2} \mathrm{Y}_{4}, \mathrm{P}_{2} \mathrm{Y}_{6}, \mathrm{P} 2 \mathrm{X} 5$ and P2X7 receptors were detected on the epithelial cells lining renal cysts in the Han:SPRD cy/+ rat model of ADPKD [376]. The expression levels of mRNA and protein for $\mathrm{P}_{2} \mathrm{Y}_{2}, \mathrm{P}_{2} \mathrm{Y}_{6}$ and $\mathrm{P} 2 \mathrm{X} 7$ receptors increased significantly as the disease developed, all mediating mechanisms potentially relevant to cyst growth and cell turnover. Blockade of the $\mathrm{P} 2 \mathrm{X} 7$ receptor with oxidised ATP (or A-438079) reduced cyst formation via ERK-dependent pathways in a zebrafish model of PKD [52]. It was suggested that nucleotides present in the cyst lumen fluid could activate $\mathrm{P} 2 \mathrm{Y}$ receptors to increase the growth of MDCK-derived cysts [377]. Attenuated flow-induced ATP release contributes to the absence of flow-sensitive, purinergic $\left[\mathrm{Ca}^{2+}\right]_{\mathrm{i}}$ signalling in human ADPKD cyst epithelial cells [421]. Monocilia of ductal epithelia are a major focus in PKD. It has been proposed that ATP is released from monocilia to act as an autocrine regulator via $\mathrm{P} 2$ receptors [138]. Deficiency of PKD-1 gene expression increases $A_{3}$ receptors in human renal cells [2]. The potential for cyst formation has been examined for two MDCK cell subclones, C7 cells that resemble principal cells and $\mathrm{C} 11$ cells that resemble $\alpha$-intercalated cells [36]. It was concluded that principal rather than intercalated cells had the ability to form cysts, based on a synergism of cAMP and ATP signalling in enhancing apical fluid secretion.

\section{Ischaemia}

There is rapid early decline of proximal tubular ATP in ischaemic acute renal failure [336]. Over-expression of manganese superoxide dismutase protects against ATP depletion-mediated cell death of proximal tubule cells occurring with ischaemia/ reperfusion injury during kidney transplantation [62].

Human antigen $\mathrm{R}(\mathrm{HuR})$ is a nucleocytoplasmic shuttling protein that binds and stabilizes mRNAs containing adenineand uridine-rich elements. ATP depletion from proximal tubule cells during ischaemia results in heightened $\mathrm{HuR}$ protein translation and suggests a role for HuR in protecting kidney epithelia from injury during ischaemic stress [175]. STAT 3, a member of the family of signal transducers and activators of transcription, inhibits apoptosis of human proximal tubular epithelial cells induced by ATP depletion during ischaemia [395].

ATP depletion of MDCK cells has been used as an in vitro model of renal ischaemia and Rho GTPase signalling shown to regulate tight junction assembly and protect tight junctions during ATP depletion [110]. It has been claimed that in renal ischaemia, the ATP depletion-induced alteration in membrane transport function and cell viability are due to reactive oxygen species generation and cytosolic PLA $_{2}$ activation in proximal tubular cells [209]. Hepatocyte growth factor has been shown to enhance recovery from renal tubular ischaemia and to promote adhesion of the ATP-depleted renal collecting duct cell line, mIMCD-3, in a MAPK-dependent manner [228]. Restoration after ischaemia by perfusion of ATP- $\mathrm{MgCl}_{2}$ was described early [104,335]. $A_{3}$ receptor knock-out mice are protected against ischaemic renal failure [208]. Ischaemia remodels filamentous actin leading to desquamation of proximal tubular epithelial cells via ATP depletion-induced p38 MAPK-HSP27 signalling [72]. These findings are of potential pathophysiological importance for understanding the overall involvement of the actin cytoskeleton in cell detachment during ischaemia. Deficiency or inhibition of the ectonucleotidase $\mathrm{CD} 73$ protected against kidney ischaemiareperfusion injury and the authors suggested that AMP may play a direct protective role against this type of injury [305]. In a later study, it was claimed that CD73 protects the kidney from ischaemia-reperfusion injury through adenosine production and reduction of free radicals [177]. The role of adenosine in protection from acute kidney injury has been discussed [425].

\section{Nephritis}

Glomerulonephritis is a leading cause of end-stage renal disease and its treatment is non-specific immunosuppression, which has significant adverse side effects. Increased expression of the pro-apoptotic ATP-sensitive P2X7 receptors has been demonstrated in both experimental and human glomerulonephritis and opens up the possibility that $\mathrm{P} 2 \mathrm{X} 7$ receptor antagonists may have therapeutic potential [378]. Indeed, a later paper from this group showed that P2X7 receptor deficiency attenuated renal injury in experimental glomerulonephritis [368]. In $\mathrm{P}_{2} \mathrm{Y}_{1}$ receptor knock-out mice, there is protection against capillary loss, fibrosis and death by renal failure during experimental crescentic glomerulonephritis [134]. Treatment with an adenosine uptake inhibitor attenuates glomerulonephritis in mice [262]. Activation of $\mathrm{A}_{2 \mathrm{~A}}$ receptors has been proposed as a treatment for macrophagemediated experimental glomerulonephritis ([100]; see also [85]). In experimental mesangial proliferative glomerulonephritis in the rat (anti-Thy-1 model), there is a pronounced mesangial cell proliferative response leading to glomerular hypercellularity. In the anti-Thy-1 model, PPADS specifically and dose-dependently reduced early (day 3 ) but not late (day 8) mesangial cell proliferation [313]. The authors also reported that $\mathrm{P} 2 \mathrm{Y}_{2}$ and $\mathrm{P} 2 \mathrm{Y}_{6}$ receptors showed a transient marked increase in expression during anti-Thy-1 disease. There are significant pro-inflammatory activities of extracellular nucleotides during anti-Thy-1 nephritis, and an anti-inflammatory 
role for glomerular ecto-nucleotidases suggested to convert ATP and ADP into anti-inflammatory adenosine [292]. Tuboglomerular feedback is diminished in Thy-1 nephritic rats, but this is improved by exogenous 5'-nucleotidase [363].

Lupus nephritis is a frequent and potentially fatal complication of systemic lupus erythematosus. $\mathrm{A}_{2 \mathrm{~A}}$ receptor activation reduced inflammation in the kidneys of MRL/lpr mice and it was suggested that this could be considered as a novel therapeutic approach for human lupus nephritis [431]. In a recent paper, it has been reported that $\mathrm{P} 2 \mathrm{X} 7$ receptor blockade attenuates lupus nephritis by inhibiting NLRP3/ASC/caspase1 inflammasome activation [436].

\section{Hypertension}

Hypertension is a feature of chronic renal disease and it has been claimed that this is largely due to sympathetic overactivity triggered by afferent signals emanating from the kidney and resetting sympathetic tone by stimulation of hypothalamic centres [268]. Both essential hypertensive patients and patients with renal artery stenosis show a dose-dependent vasodilation following adenosine infusion [407,408]. Enhanced increase in $\left[\mathrm{Ca}^{2+}\right]_{i}$ was found in mesangial cells in response to ATP in spontaneously hypertensive rats [226] and NO can increase P2Y receptor resensitization [227].

The kidney plays a dominant role in the development and maintenance of hypertension and the shift of renal autoregulation towards higher pressure underlying sodium-insensitive hypertension [362]. There is an enhanced P2 receptor-mediated vasoconstriction of afferent and efferent arterioles in chronic Ang IIinduced hypertensive rats [94]. It was claimed that gap junction Cx37 and $\mathrm{Cx} 40$ transduce purinergic signals mediating renal autoregulation [364]. In a recent paper, it was shown that ATP release through $\mathrm{Cx} 30$ is part of a local regulatory system intrinsic to the aldosterone-sensitive distal nephron important for control of sodium excretion [246]. They showed that loss of paracrine ATP feedback regulation of $\mathrm{ENaC}$ to respond to changes in sodium levels contributed to salt-sensitive hypertension in $\mathrm{C} \times 30^{-/-}$mice. Purinergic receptors contribute to early mesangial cell transformation and renal vessel hypertrophy during Ang IIinduced hypertension [114]. Renal interstitial adenosine is increased in Ang II-induced hypertensive rats [93]. Mice lacking $\mathrm{P} \mathrm{Y}_{2}$ receptors have salt-resistant hypertension [309]. There is an exaggerated response to adenosine in kidneys from high salt-fed rats [223]. While the P2X7 receptor is only weakly expressed in healthy kidney glomerulus, it is significantly upregulated in ren-2 transgenic hypertension [393]. In a recent paper, it was shown that P2X7 receptor antagonism prevented the development of salt-sensitive hypertension and renal injury in Dahl salt-sensitive rats [176]. ATP-induced hypotension is associated with alteration of sympathetic nerve activity mediated through vagal afferent pathways [366]. It has been reported that there is an increase in ATP hydrolysis resulting from an increase in ecto-5'-nucleotidase activity and accumulation of adenosine in the kidney of hypertensive animals [96]. A high salt diet given to Ang II hypertensive rats significantly impairs autoregulation of rat juxtamedullary afferent arterioles, which is associated with a decline in afferent arteriolar reactivity to ATP mediated by P2X1 receptors [154]. However, reactivity to UTP via P2Y 2 receptors or to adenosine via P1 receptors was unchanged. It was suggested that understanding this mechanism may lead to therapeutic interventions to prevent renal decline early in the hypertension progression. The hypertensive responses to $\mathrm{L}-\mathrm{N}^{\mathrm{G}}$ nitroarginine methyl ester and Ang II were attenuated in $\mathrm{A}_{1}$ receptor knockout mice [99]. Adenosine, acting via $\mathrm{A}_{1}$ receptors in the proximal tubule, modulates deoxycorticosterone acetatesalt hypertension in mice [404].

\section{Diabetic nephropathy}

Diabetic nephropathy is the most common cause of end-stage renal disease. Lack of $A_{1}$ receptors augments diabetic hyperfiltration and glomerular injury [83]. Treatment with adenosine receptor agonists protected diabetic rats from nephropathy by exerting hypoglycaemic and antioxidant effects as well as reducing gene expression of proinflammatory cytokines [78]. A recent review is concerned with the targeting of adenosine signalling via $\mathrm{A}_{2 \mathrm{~B}}$ antagonists for the treatment of diabetic nephropathy [301].

Increased ATP release induced by hyperglycaemia may contribute to mesangial extracellular matrix expansion that occurs in diabetes [346]. Increased expression of P2X7 receptors was shown in the streptozotocin diabetic rat model, mainly in podocytes but also in endothelial and mesangial cells [393]. Diabetic milieu, represented by high glucose concentrations, affects purinergic modulation of glucose transport into podocytes, which may play a role in the development of diabetic podocytopathy [182]. P2X4 receptors mediate high glucoseinduced activation of the NOD-like receptor 3 inflammasome, regulate IL-1 family cytokine secretion and cause the development of tubulointerstitial inflammation in diabetic nephropathy [54].

A major limitation in chronic lithium treatment for bipolar patients is the development of nephrogenic diabetes insipidus, which manifests as polyuria, polydipsia and reduced ability to concentrate urine associated with a lack of response of the medullary collecting duct to AVP. Genetic deletion of the $\mathrm{P}_{2} \mathrm{Y}_{2}$ receptor offers significant resistance to the development of lithium-induced nephrogenic diabetes insipidus polyuria [435].

Inflammation

ATP, via $\mathrm{P}_{2} \mathrm{Y}_{2}$ receptors, inhibits inducible NOS (iNOS) in cultured mesangial cells and it has been suggested that it may play a critical role for iNOS expression and synthesis of NO during glomerular inflammatory disorders [249]. ATP has also 
been claimed to produce long-term pro-inflammatory effects in rat mesangial cells via it degradation to adenosine and action on $\mathrm{A}_{2 \mathrm{~A}}$ receptors, resulting in $\mathrm{PLA}_{2}$ and cytokine induction [322]. The $\mathrm{P} 2 \mathrm{X} 7$ receptor plays a major role in the inflammatory process, since activation leads to release of inflammatory cytokines $[55,204]$. Activation of $\mathrm{A}_{2 \mathrm{~A}}$ receptors prevents progressive kidney fibrosis in a model of immuneassociated chronic inflammation [101] and of obstructive nephropathy [418].

\section{Hyper- and hypothyroidism}

ATP-mediated vasoconstriction of perfused rat kidney was increased in hyperthyroid kidneys and severely attenuated in kidneys from hypothyroid rats and the vasodilator response abolished [386]. Experimental hyperthyroidism modifies binding of $A_{1}$ and $A_{2 A}$ agonists in rat kidney, and this might be responsible for the incapacity for urine concentration seen in the hypothyroid kidney [92].

\section{Nephrotoxicant injury}

Reduction of drug-induced nephrotoxicity by ATP- $\mathrm{MgCl}_{2}$ was reported [355]. PKB activation increases intracellular ATP levels and decreases necrosis in proximal tubular cells injured by nephrotoxicants [330]. ATP levels in kidneys are decreased by ingestion of tullidora, a poisonous plant, which may partly explain its acute toxic effects and mortality [173]. Cisplatin is a potent anti-neoplastic drug whose clinical use is limited by its ability to induce nephrotoxicity. It has been suggested that adenosine may be involved in the haemodynamic changes in the kidney induced by cisplatin [128]. Cisplatin upregulates $A_{1}$ receptors in rat kidney [25] and $A_{1}$ receptor antagonists have a protective effect against cisplatininduced acute kidney injury in rats [107]. Adenosine antagonists have protective effects against acute renal failure $[156,253,358] . A_{1}$ receptor antagonists are effective against the development of nephrotoxicity by cyclosporine, an immunosuppressive agent [18]. Cyclosporine increases plasma levels of adenosine in kidney transplant patients [43]. $\mathrm{A}_{3}$ receptor antagonism is effective against acute tacrolimus toxicity [241].

\section{Renal transplants}

An ATP release assay has been used to help determine the risks of developing infection or rejection in renal transplant recipients [42]. The beneficial effects of adenosine and phosphate in kidney transplant preservation have been claimed [23].

\section{Summary}

Purines have been shown to control TGF, regulate renin release and regulate tubular ion and water transport. There is autocrine/paracrine release of ATP from epithelial and endothelial cells, as well as release as a cotransmitter from sympathetic nerves. Purinergic signalling is involved in kidney disorders, including PKD, nephritis, hypertension, diabetes and nephrotoxicant injury, and purinergic therapeutic strategies are being explored to treat these diseases.

Acknowledgments The authors are very grateful to Dr Gillian E. Knight for her invaluable assistance in the preparation of this review article. The University/British Heart Foundation Centre for Cardiovascular Science is funded by The British Heart Foundation, Kidney Research UK.

\section{References}

1. AbouAlaiwi WA, Takahashi M, Mell BR, Jones TJ, Ratnam S, Kolb RJ, Nauli SM (2009) Ciliary polycystin-2 is a mechanosensitive calcium channel involved in nitric oxide signaling cascades. Circ Res 104:860-869

2. Aguiari G, Varani K, Bogo M, Mangolini A, Vincenzi F, Durante C, Gessi S, Sacchetto V, Catizone L, Harris P, Rizzuto R, Borea PA, Del Senno L (2009) Deficiency of polycystic kidney disease-1 gene (PKD1) expression increases $\mathrm{A}_{3}$ adenosine receptors in human renal cells: implications for cAMP-dependent signalling and proliferation of PKD1-mutated cystic cells. Biochim Biophys Acta 1792:531-540

3. Akimova AO, Bourcier N, Taurin S, Bundey RA, Grygorczyk K, Gekle M, Insel PA, Dulin NO, Orlov SN (2005) $\mathrm{Cl}^{-}$secretion in ATP-treated renal epithelial C7-MDCK cells is mediated by activation of $\mathrm{P}_{2 \mathrm{Y} 1}$ receptors, phospholipase $\mathrm{A}_{2}$ and protein kinase A. $\mathrm{J}$ Physiol 568:789-801

4. Akimova OA, Grygorczyk A, Bundey RA, Bourcier N, Gekle M, Insel PA, Orlov SN (2006) Transient activation and delayed inhibition of $\mathrm{Na}+, \mathrm{K}+, \mathrm{Cl}-$ cotransport in ATP-treated C11-MDCK cells involve distinct $\mathrm{P} 2 \mathrm{Y}$ receptor subtypes and signaling mechanisms. J Biol Chem 281:31317-31325

5. Akimova OA, Taurin S, Dulin NO, Orlov SN (2008) Purinergic inhibition of $\mathrm{Na}+, \mathrm{K}+, \mathrm{Cl}-$ cotransport in $\mathrm{C} 11-\mathrm{MDCK}$ cells: role of stress-activated protein kinases. Purinergic Signal 4:183-191

6. Amann K, Veelken R (2003) Mechanisms and consequences of sympathetic hyperactivity in renal disease. Clin Nephrol 60(Suppl 1):S81-S92

7. Apicella L, Fabbretti E (2012) P2X3 receptor expression by HEK cells conditions their survival. Purinergic Signal 8:295-300

8. Assaife-Lopes N, Wengert M, Pinheiro AA, Landgraf SS, Paes-deCarvalho R, Leao-Ferreira LR, Caruso-Neves C (2009) Adenosine deamination to inosine in isolated basolateral membrane from kidney proximal tubule: implications for modulation of the membraneassociated protein kinase A. Arch Biochem Biophys 486:44-50

9. Awad AS, Rouse M, Liu L, Vergis AL, Rosin DL, Linden J, Sedor JR, Okusa MD (2008) Activation of adenosine 2A receptors preserves structure and function of podocytes. J Am Soc Nephrol 19: $59-68$

10. Bagorda A, Guerra L, Di SF, Helmle-Kolb C, Favia M, Jacobson KA, Casavola V, Reshkin SJ (2002) Extracellular adenine nucleotides regulate $\mathrm{Na}^{+} / \mathrm{H}^{+}$exchanger NHE3 activity in A6-NHE3 
transfectants by a cAMP/PKA-dependent mechanism. J Membr Biol 188:249-259

11. Bailey MA (2004) Inhibition of bicarbonate reabsorption in the rat proximal tubule by activation of luminal $\mathrm{P}_{2} \mathrm{Y}_{1}$ receptors. Am J Physiol Ren Physiol 287:F789-F796

12. Bailey MA, Shirley DG (2009) Effects of extracellular nucleotides on renal tubular solute transport. Purinergic Signal 5:473-480

13. Bailey MA, Hillman KA, Unwin RJ (2000) P2 receptors in the kidney. J Auton Nerv Syst 81:264-270

14. Bailey MA, Imbert-Teboul M, Turner C, Marsy S, Srai K, Burnstock G, Unwin RJ (2000) Axial distribution and characterization of basolateral $\mathrm{P} 2 \mathrm{Y}$ receptors along the rat renal tubule. Kidney Int 58:1893-1901

15. Bailey MA, Imbert-Teboul M, Turner C, Srai SK, Burnstock G, Unwin RJ (2001) Evidence for basolateral $\mathrm{P}_{2} \mathrm{Y}_{6}$ receptors along the rat proximal tubule: functional and molecular characterization. J Am Soc Nephrol 12:1640-1647

16. Bailey MA, Turner CM, Hus-Citharel A, Marchetti J, ImbertTeboul M, Milner P, Burnstock G, Unwin RJ (2004) P2Y receptors present in the native and isolated rat glomerulus. Nephron Physiol 96:79-90

17. Bailey MA, Unwin RJ, Shirley DG (2012) P2X receptors and kidney function. WIREs Memb Transplant Signal 1:503-511. doi: 10.1002/wmts.40

18. Balakrishnan VS, von Ruhland CJ, Griffiths DF, Coles GA, Williams JD (1996) Effects of a selective adenosine $A_{1}$ receptor antagonist on the development of cyclosporin nephrotoxicity. Br J Pharmacol 117:879-884

19. Banderali U, Brochiero E, Lindenthal S, Raschi C, Bogliolo S, Ehrenfeld J (1999) Control of apical membrane chloride permeability in the renal A6 cell line by nucleotides. J Physiol 519(Pt 3):737-751

20. Bauerle JD, Grenz A, Kim JH, Lee HT, Eltzschig HK (2011) Adenosine generation and signaling during acute kidney injury. $\mathrm{J}$ Am Soc Nephrol 22:14-20

21. Bell PD, Lapointe JY, Sabirov R, Hayashi S, Peti-Peterdi J, Manabe K, Kovacs G, Okada Y (2003) Macula densa cell signaling involves ATP release through a maxi anion channel. Proc Natl Acad Sci U S A 100:4322-4327

22. Bell PD, Komlosi P, Zhang ZR (2009) ATP as a mediator of macula densa cell signalling. Purinergic Signal 5:461-471

23. Belzer FO, Sollinger HW, Glass NR, Miller DT, Hoffmann RM, Southard JH (1983) Beneficial effects of adenosine and phosphate in kidney preservation. Transplantation 36:633-635

24. Bertelli R, Bodria M, Nobile M, Alloisio S, Barbieri R, Montobbio G, Patrone P, Ghiggeri GM (2011) Regulation of innate immunity by the nucleotide pathway in children with idiopathic nephrotic syndrome. Clin Exp Immunol 166:55-63

25. Bhat SG, Mishra S, Mei Y, Nie Z, Whitworth CA, Rybak LP, Ramkumar V (2002) Cisplatin up-regulates the adenosine $A_{1}$ receptor in the rat kidney. Eur J Pharmacol 442:251-264

26. Bidet M, De Renzis G, Martial S, Rubera I, Tauc M, Poujeol P (2000) Extracellular ATP increases $\left[\mathrm{CA}^{2+}\right]_{\mathrm{i}}$ in distal tubule cells. I. Evidence for a P2Y2 purinoceptor. Am J Physiol Ren Physiol 279: F92-F101

27. Blantz RC, Singh P, Deng A, Thomson SC, Vallon V (2012) Acute saline expansion increases nephron filtration and distal flow rate but maintains tubuloglomerular feedback responsiveness: role of adenosine $A_{1}$ receptors. Am J Physiol Ren Physiol 303:F405-F411

28. Boone M, Deen PM (2008) Physiology and pathophysiology of the vasopressin-regulated renal water reabsorption. Pflugers Arch 456: $1005-1024$

29. Boone M, Kortenoeven ML, Robben JH, Tamma G, Deen PM (2011) Counteracting vasopressin-mediated water reabsorption by ATP, dopamine, and phorbol esters: mechanisms of action. Am J Physiol Ren Physiol 300:F761-F771
30. Booth JW, Tam FW, Unwin RJ (2012) P2 purinoceptors: Renal pathophysiology and therapeutic potential. Clin Nephrol 78: 154-163

31. Bourcier N, Grygorczyk R, Gekle M, Berthiaume Y, Orlov SN (2002) Purinergic-induced ion current in monolayers of C7MDCK cells: role of basolateral and apical ion transporters. $\mathrm{J}$ Membr Biol 186:131-143

32. Bouyer P, Paulais M, Cougnon M, Hulin P, Anagnostopoulos T, Planelles G (1998) Extracellular ATP raises cytosolic calcium and activates basolateral chloride conductance in Necturus proximal tubule. J Physiol 510:535-548

33. Brown JN, Payne BL, Smith TM, Sulya LL (1977) Effects of ATP, $\mathrm{NADH}$ and aldosterone on citrate synthase from bovine kidney cortex. Int J Biochem 8:437-440

34. Brown R, Ollerstam A, Johansson B, Skøtt O, Gebre-Medhin S, Fredholm B, Persson AE (2001) Abolished tubuloglomerular feedback and increased plasma renin in adenosine $\mathrm{A}_{1}$ receptor-deficient mice. Am J Physiol Regul Integr Comp Physiol 281:R1362-R1367

35. Brunette MG, Mailloux J, Hilal G (1999) ATP directly enhances calcium channels in the luminal membrane of the distal nephron. $\mathrm{J}$ Cell Physiol 181:416-423

36. Buchholz B, Teschemacher B, Schley G, Schillers H, Eckardt KU (2011) Formation of cysts by principal-like MDCK cells depends on the synergy of cAMP- and ATP-mediated fluid secretion. J Mol Med (Berl) 89:251-261

37. Bugaj V, Sansom SC, Wen D, Hatcher LI, Stockand JD, Mironova E (2012) Flow-sensitive $\mathrm{K}^{+}$-coupled ATP secretion modulates activity of the epithelial $\mathrm{Na}^{+}$channel in the distal nephron. J Biol Chem 287: 38552-38558

38. Bührle CP, Scholz H, Nobiling R, Taugner R (1986) Junctional transmission in renin-containing and smooth muscle cells of the afferent arteriole. Pflugers Arch 406:578-586

39. Burnstock G (2002) Purinergic signalling and vascular cell proliferation and death. Arterioscler Thromb Vasc Biol 22:364-373

40. Burnstock G, Knight GE (2004) Cellular distribution and functions of P2 receptor subtypes in different systems. Int Rev Cytol 240:31-304

41. Cabral PD, Garvin JL (2011) Flow-induced NO production is dependent on TRPV4 activation and ATP release in thick ascending limbs. FASEB J 25:666

42. Cadillo-Chávez R, de Echegaray S, Santiago-Delpín EA, Rodríguez-Trinidad AT, Camacho-Carrazo B, Alfaro T, Saavedra-Pozo M, Carrasquillo L, González-Caraballo ZA, Morales-Otero LA (2006) Assessing the risk of infection and rejection in Hispanic renal transplant recipients by means of an adenosine triphosphate release assay. Transplant Proc 38:918920

43. Capechi PL, Rechichi S, Lazzerini PE, Collini A, Guideri F, Ruggieri G, Carmellini M, Laghi-Pasini F (2005) Cyclosporin and tacrolimus increase plasma levels of adenosine in kidney transplanted patients. Transpl Int 18:289-295

44. Carlström M, Wilcox CS, Welch WJ (2010) Adenosine $A_{2}$ receptors modulate tubuloglomerular feedback. Am J Physiol Ren Physiol 299:F412-F417

45. Carroll MA, Cheng MK, Liclican EL, Li J, Doumad AB, McGiff JC (2005) Purinoceptors in renal microvessels: adenosine-activated and cytochrome P450 monooxygenase-derived arachidonate metabolites. Pharmacol Rep 57(Suppl):191-195

46. Castrop H (2007) Mediators of tubuloglomerular feedback regulation of glomerular filtration: ATP and adenosine. Acta Physiol (Oxf) 189:3-14

47. Castrop H, Huang Y, Hashimoto S, Mizel D, Hansen P, Theilig F, Bachmann S, Deng C, Briggs J, Schnermann J (2004) Impairment of tubuloglomerular feedback regulation of GFR in ecto-5'-nucleotidase/CD73-deficient mice. J Clin Invest 114:634-642 
48. Cha SH, Jung KY, Endou H (1995) Effect of $\mathrm{P}_{2 Y}$-purinoceptor stimulation on renal gluconeogenesis in rats. Biochem Biophys Res Commun 211:454-461

49. Cha SH, Sekine T, Endou H (1998) P2 purinoceptor localization along rat nephron and evidence suggesting existence of subtypes $\mathrm{P}_{2} \mathrm{Y}_{1}$ and $\mathrm{P} 2 \mathrm{Y}_{2}$. Am J Physiol 274:F1006-F1014

50. Chabardes-Garonne D, Mejean A, Aude JC, Cheval L, Di SA, Gaillard MC, Imbert-Teboul M, Wittner M, Balian C, Anthouard V, Robert C, Segurens B, Wincker P, Weissenbach J, Doucet A, Elalouf JM (2003) A panoramic view of gene expression in the human kidney. Proc Natl Acad Sci U S A 100:13710-13715

51. Chan CM, Unwin RJ, Bardini M, Oglesby IB, Ford APDW, Townsend-Nicholson A, Burnstock G (1998) Localization of the $\mathrm{P} 2 \mathrm{X}_{1}$ purinoceptors by autoradiography and immunohistochemistry in rat kidneys. Am J Physiol 274:F799-F804

52. Chang MY, Lu JK, Tian YC, Chen YC, Hung CC, Huang YH, Chen YH, Wu MS, Yang CW, Cheng YC (2011) Inhibition of the P2X7 receptor reduces cystogenesis in PKD. J Am Soc Nephrol 22:1696-1706

53. Chapin HC, Caplan MJ (2010) The cell biology of polycystic kidney disease. J Cell Biol 191:701-710

54. Chen K, Zhang J, Zhang W, Zhang J, Yang J, Li K, He Y (2013) ATP-P2X4 signaling mediates NLRP3 inflammasome activation: a novel pathway of diabetic nephropathy. Int J Biochem Cell Biol 45: 932-943

55. Chessell IP, Hatcher JP, Bountra C, Michel AD, Hughes JP, Green P, Egerton J, Murfin M, Richardson J, Peck WL, Grahames CB, Casula MA, Yiangou Y, Birch R, Anand P, Buell GN (2005) Disruption of the $\mathrm{P}_{2} \mathrm{X}_{7}$ purinoceptor gene abolishes chronic inflammatory and neuropathic pain. Pain 114:386-396

56. Chittezhath M, Frump AL, Jourquin J, Lobdell N, Eid JE (2008) The proto-oncoprotein SYT (SS18) controls ATP release and regulates cyst formation by polarized MDCK cells. Exp Cell Res 314: 3551-3562

57. Churchill PC, Bidani AK (1982) Hypothesis: adenosine mediates hemodynamic changes in renal failure. Med Hypotheses 8: 275-285

58. Churchill PC, Churchill MC (1985) $A_{1}$ and $A_{2}$ adenosine receptor activation inhibits and stimulates renin secretion of rat renal cortical slices. J Pharmacol Exp Ther 232:589-594

59. Churchill PC, Ellis VR (1993) Purinergic $P_{2 Y}$ receptors stimulate renin secretion by rat renal cortical slices. J Pharmacol Exp Ther 266:160-163

60. Cotrina ML, Lin JH, ves-Rodrigues A, Liu S, Li J, zmi-Ghadimi H, Kang J, Naus CC, Nedergaard M (1998) Connexins regulate calcium signaling by controlling ATP release. Proc Natl Acad Sci U S A 95(ves-Rodrigues A): $15735-15740$

61. Crawford C, Kennedy-Lydon TM, Callaghan H, Sprott C, Simmons RL, Sawbridge L, Syme HM, Unwin RJ, Wildman SS, PeppiattWildman CM (2011) Extracellular nucleotides affect pericytemediated regulation of rat in situ vasa recta diameter. Acta Physiol (Oxf) 202:241-251

62. Cruthirds DL, Saba H, Millan-Crow LA (2005) Overexpression of manganese superoxide dismutase protects against ATP depletionmediated cell death of proximal tubule cells. Arch Biochem Biophys 437:96-105

63. Cuffe JE, Bielfeld-Ackermann A, Thomas J, Leipziger J, Korbmacher C (2000) ATP stimulates $\mathrm{Cl}^{-}$secretion and reduces amiloride-sensitive $\mathrm{Na}^{+}$absorption in $\mathrm{M}-1$ mouse cortical collecting duct cells. J Physiol 524:77-90

64. Cupples WA, Braam B (2007) Assessment of renal autoregulation. Am J Physiol Ren Physiol 292:F1105-F1123

65. Dai Y, Zhang W, Wen J, Zhang Y, Kellems RE, Xia Y (2011) $A_{2 B}$ adenosine receptor-mediated induction of IL-6 promotes CKD. J Am Soc Nephrol 22:890-901
66. Davies JP, Robson L (2010) Pharmacological properties and physiological function of a P2X-like current in single proximal tubule cells isolated from frog kidney. J Membr Biol 237:79-91

67. Deetjen P, Thomas J, Lehrmann H, Kim SJ, Leipziger J (2000) The luminal $\mathrm{P} 2 \mathrm{Y}$ receptor in the isolated perfused mouse cortical collecting duct. J Am Soc Nephrol 11:1798-1806

68. Di Garbo A, Alloisio S, Nobile M (2012) P2X7 receptor-mediated calcium dynamics in HEK293 cells: experimental characterization and modelling approach. Phys Biol 9:026001

69. Di Sole F (2008) Adenosine and renal tubular function. Curr Opin Nephrol Hypertens 17:399-407

70. Díaz-Sylvester P, Mac Laughlin M, Amorena C (2001) Peritubular fluid viscosity modulates $\mathrm{H}^{+}$flux in proximal tubules through $\mathrm{NO}$ release. Am J Physiol Ren Physiol 280:F239-F243

71. Dobrowolski L, Walkowska A, Kompanowska-Jezierska E, Kuczeriszka M, Sadowski J (2007) Effects of ATP on rat renal haemodynamics and excretion: role of sodium intake, nitric oxide and cytochrome P450. Acta Physiol (Oxf) 189:77-85

72. Du J, Zhang L, Yang Y, Li W, Chen L, Ge Y, Sun C, Zhu Y, Gu L (2010) ATP depletion-induced actin rearrangement reduces cell adhesion via $\mathrm{p} 38$ MAPK-HSP27 signaling in renal proximal tubule cells. Cell Physiol Biochem 25:501-510

73. Dubey RK, Gillespie DG, Mi Z, Jackson EK (2005) Adenosine inhibits PDGF-induced growth of human glomerular mesangial cells via $\mathrm{A}_{2 \mathrm{~B}}$ receptors. Hypertension 46:628-634

74. Ecelbarger CA, Maeda Y, Gibson CC, Knepper MA (1994) Extracellular ATP increases intracellular calcium in rat terminal collecting duct via a nucleotide receptor. Am J Physiol 267:F998F1006

75. Edgecombe M, Craddock HS, Smith DC, McLennan AG, Fisher MJ (1997) Diadenosine polyphosphate-stimulated gluconeogenesis in isolated rat proximal tubules. Biochem J 323(Pt 2):451-456

76. Edwards RM (2002) Basolateral, but not apical, ATP inhibits vasopressin action in rat inner medullary collecting duct. Eur J Pharmacol 438:179-181

77. Eladari D, Chambrey R, Peti-Peterdi J (2012) A new look at electrolyte transport in the distal tubule. Annu Rev Physiol 74: 325-349

78. Elsherbiny NM, Abd El Galil KH, Gabr MM, Al-Gayyar MM, Eissa LA, El-Shishtawy MM (2012) Reno-protective effect of NECA in diabetic nephropathy: implication of IL-18 and ICAM1. Eur Cytokine Netw 23:78-86

79. Eltze M, Ullrich B (1996) Characterization of vascular $\mathrm{P}_{2}$ purinoceptors in the rat isolated perfused kidney. Eur J Pharmacol 306:139-152

80. Elwi AN, Damaraju VL, Kuzma ML, Mowles DA, Baldwin SA, Young JD, Sawyer MB, Cass CE (2009) Transepithelial fluxes of adenosine and 2'-deoxyadenosine across human renal proximal tubule cells: roles of nucleoside transporters hENT1, hENT2, and hCNT3. Am J Physiol Ren Physiol 296:F1439-F1451

81. Enjyoji K, Sevigny J, Lin Y, Frenette PS, Christie PD, Esch JS, Imai M, Edelberg JM, Rayburn $\mathrm{H}$, Lech M, Beeler DL, Csizmadia E, Wagner DD, Robson SC, Rosenberg RD (1999) Targeted disruption of cd39/ATP diphosphohydrolase results in disordered hemostasis and thromboregulation. Nat Med 5:1010-1017

82. Eppel GA, Ventura S, Evans RG (2006) Regional vascular responses to ATP and ATP analogues in the rabbit kidney in vivo: roles for adenosine receptors and prostanoids. Br J Pharmacol 149: 523-531

83. Faulhaber-Walter R, Chen L, Oppermann M, Kim SM, Huang Y, Hiramatsu N, Mizel D, Kajiyama H, Zerfas P, Briggs JP, Kopp JB, Schnermann J (2008) Lack of A1 adenosine receptors augments diabetic hyperfiltration and glomerular injury. J Am Soc Nephrol 19:722-730 
84. Feng MG, Navar LG (2010) Afferent arteriolar vasodilator effect of adenosine predominantly involves adenosine A2B receptor activation. Am J Physiol Ren Physiol 299:F310-F315

85. Ferenbach DA, Hughes $J$ (2011) Adenosine $A_{2 A}$ agonists as therapy for glomerulonephritis. Kidney Int 80:329-331

86. Fernandez O, Wangensteen R, Osuna A, Vargas F (2000) Renal vascular reactivity to $\mathrm{P}_{2}$-purinoceptor activation in spontaneously hypertensive rats. Pharmacology 60:47-50

87. Fischer KG, Saueressig U, Jacobshagen C, Wichelmann A, Pavenstädt H (2001) Extracellular nucleotides regulate cellular functions of podocytes in culture. Am J Physiol Ren Physiol 281: F1075-F1081

88. Fischer W, Wirkner K, Weber M, Eberts C, Köles L, Reinhardt R, Franke H, Allgaier C, Gillen C, Illes P (2003) Characterization of $\mathrm{P}_{2} \mathrm{X}_{3}, \mathrm{P}_{2} \mathrm{Y}_{1}$ and $\mathrm{P}_{2} \mathrm{Y}_{4}$ receptors in cultured HEK293-hP2X $\mathrm{X}_{3}$ cells and their inhibition by ethanol and trichloroethanol. J Neurochem 85:779-790

89. Fischer W, Franke H, Gröger-Arndt H, Illes P (2005) Evidence for the existence of $\mathrm{P} 2 \mathrm{Y}_{1,2,4}$ receptor subtypes in HEK-293 cells: reactivation of $\mathrm{P}_{2} \mathrm{Y}_{1}$ receptors after repetitive agonist application. Naunyn Schmiedebergs Arch Pharmacol 371:466-472

90. Fish RS, Klootwijk E, Tam FW, Kleta R, Wheeler DC, Unwin RJ, Norman J (2013) ATP and arterial calcification. Eur J Clin Investig 43:405-412

91. Franco M, Bell PD, Navar LG (1989) Effect of adenosine A1 analogue on tubuloglomerular feedback mechanism. Am J Physiol 257:F231-F236

92. Franco M, Galicia O, Quintana A, Martínez F (2004) Experimental hypothyroidism modifies specific binding of $\mathrm{A}_{1}$ and $\mathrm{A}_{2 \mathrm{~A}}$ analogues to adenosine receptors in the rat kidney. Br J Pharmacol 142:461-468

93. Franco M, Bautista R, Perez-Mendez O, Gonzalez L, Pacheco U, Sanchez-Lozada LG, Santamaria J, Tapia E, Monreal R, Martinez F (2008) Renal interstitial adenosine is increased in angiotensin IIinduced hypertensive rats. Am J Physiol Ren Physiol 294:F84-F92

94. Franco M, Bautista R, Tapia E, Soto V, Santamaría J, Osorio H, Pacheco U, Sánchez-Lozada LG, Kobori H, Navar LG (2011) Contribution of renal purinergic receptors to renal vasoconstriction in angiotensin II-induced hypertensive rats. Am J Physiol Ren Physiol 300:F1301-F1309

95. Friedrich F, Weiss H, Paulmichl M, Lang F (1989) Activation of potassium channels in renal epithelioid cells (MDCK) by extracellular ATP. Am J Physiol 256:C1016-C1021

96. Fürstenau CR, Ramos DB, Vuaden FC, Casali EA, PdS M, DdS T, Gossenheimer AN, Bogo MR, Bonan CD, Barreto-Chaves ML, Sarkis JJ, Wofchuk ST (2010) L-NAME-treatment alters ectonucleotidase activities in kidney membranes of rats. Life Sci $87: 325-332$

97. Gaál K, Forgács I, Bácsalmásy Z (1976) Effect of adenosine compounds (ATP, cAMP) on renin release in vitro. Acta Physiol Acad Sci Hung 47:49-54

98. Gandhi R, Le Hir M, Kaissling B (1990) Immunolocalization of ecto-5'-nucleotidase in the kidney by a monoclonal antibody. Histochemistry 95:165-174

99. Gao X, Patzak A, Sendeski M, Scheffer PG, Teerlink T, Sällstrom J, Fredholm BB, Persson AE, Carlström M (2011) Adenosine $A_{1}$-receptor deficiency diminishes afferent arteriolar and blood pressure responses during nitric oxide inhibition and angiotensin II treatment. Am J Physiol Regul Integr Comp Physiol 301:R1669-R1681

100. Garcia GE, Truong LD, Li P, Zhang P, Du J, Chen JF, Feng L (2008) Adenosine $\mathrm{A}_{2 \mathrm{~A}}$ receptor activation and macrophage-mediated experimental glomerulonephritis. FASEB J 22:445-454

101. Garcia GE, Truong LD, Chen JF, Johnson RJ, Feng L (2011) Adenosine $\mathrm{A}_{2 \mathrm{~A}}$ receptor activation prevents progressive kidney fibrosis in a model of immune-associated chronic inflammation. Kidney Int 80:378-388
102. Garvin JL, Hong NJ (1999) Nitric oxide inhibits sodium/hydrogen exchange activity in the thick ascending limb. Am J Physiol 277: F377-F382

103. Garvin JL, Herrera M, Ortiz PA (2011) Regulation of renal $\mathrm{NaCl}$ transport by nitric oxide, endothelin, and ATP: clinical implications. Annu Rev Physiol 73:359-376

104. Garvin PJ, Jellinek M, Morgan R, Codd JE (1981) Renal cortical levels of adenosine triphosphate: restoration after prolonged ischemia by in situ perfusion of ATP- $\mathrm{MgCl}_{2}$. Arch Surg 116: 221-224

105. Geyti CS, Odgaard E, Overgaard MT, Jensen ME, Leipziger J, Praetorius HA (2008) Slow spontaneous $\left[\mathrm{Ca}^{2+}\right]_{i}$ oscillations reflect nucleotide release from renal epithelia. Pflugers Arch 455:1105-1117

106. Gheorghiu M, Van Driessche W (2004) Modeling of basolateral ATP release induced by hypotonic treatment in A6 cells. Eur Biophys J 33:412-420

107. Gill A, Wortham K, Costa D, Davis W, Ticho B, Whalley E (2009) Protective effect of tonapofylline (BG9928), an adenosine A1 receptor antagonist, against cisplatin-induced acute kidney injury in rats. Am J Nephrol 30:521-526

108. Goel M, Schilling WP (2010) Role of TRPC3 channels in ATPinduced $\mathrm{Ca}^{2+}$ signaling in principal cells of the inner medullary collecting duct. Am J Physiol Ren Physiol 299:F225-F233

109. Gomes CP, Leão-Ferreira LR, Pinheiro AA, Gomes-Quintana E, Wengert M, Lopes AG, Caruso-Neves C (2008) Crosstalk between the signaling pathways triggered by angiotensin II and adenosine in the renal proximal tubules: implications for modulation of $\mathrm{Na}^{+}-$ ATPase activity. Peptides 29:2033-2038

110. Gopalakrishnan S, Raman N, Atkinson SJ, Marrs JA (1998) Rho GTPase signaling regulates tight junction assembly and protects tight junctions during ATP depletion. Am J Physiol 275:C798C809

111. Gopalakrishnan S, Hallett MA, Atkinson SJ, Marrs JA (2007) aPKC-PAR complex dysfunction and tight junction disassembly in renal epithelial cells during ATP depletion. Am J Physiol Cell Physiol 292:C1094-C1102

112. Gorelik J, Zhang Y, Sánchez D, Shevchuk A, Frolenkov G, Lab M, Klenerman D, Edwards C, Korchev Y (2005) Aldosterone acts via an ATP autocrine/paracrine system: the Edelman ATP hypothesis revisited. Proc Natl Acad Sci U S A 102:15000-15005

113. Gottlieb SS (2001) Are all beta-blockers the same for chronic heart failure? Curr Cardiol Rep 3:124-129

114. Graciano ML, Nishiyama A, Jackson K, Seth DM, Ortiz RM, Prieto-Carrasquero MC, Kobori H, Navar LG (2008) Purinergic receptors contribute to early mesangial cell transformation and renal vessel hypertrophy during angiotensin II-induced hypertension. Am J Physiol Ren Physiol 294:F161-F169

115. Greiber S, Münzel T, Kästner S, Müller B, Schollmeyer P, Pavenstädt H (1998) NAD(P)H oxidase activity in cultured human podocytes: effects of adenosine triphosphate. Kidney Int 53:654 663

116. Grenz A, Kim JH, Bauerle JD, Tak E, Eltzschig HK, Clambey ET (2012) Adora $2 \mathrm{~b}$ adenosine receptor signaling protects during acute kidney injury via inhibition of neutrophil-dependent TNF- $\alpha$ release. J Immunol 189:4566-4573

117. Guan Z, Inscho EW (2011) Role of adenosine 5'-triphosphate in regulating renal microvascular function and in hypertension. Hypertension 58:333-340

118. Guan Z, Osmond DA, Inscho EW (2007) Purinoceptors in the kidney. Exp Biol Med (Maywood) 232:715-726

119. Guan Z, Fuller BS, Yamamoto T, Cook AK, Pollock JS, Inscho EW (2010) Pentosan polysulfate treatment preserves renal autoregulation in ANG II-infused hypertensive rats via normalization of P2X1 receptor activation. Am J Physiol Ren Physiol 298:F1276-F1284 
120. Guerra L, Favia M, Fanelli T, Calamita G, Svetlo M, Bagorda A, Jacobson KA, Reshkin SJ, Casavola V (2004) Stimulation of Xenopus P2Y1 receptor activates CFTR in A6 cells. Pflugers Arch 449:66-75

121. Gutierrez AM, Lou X, Erik A, Persson G, Ring A (1999) $\mathrm{Ca}^{2+}$ response of rat mesangial cells to ATP analogues. Eur J Pharmacol 369:107-112

122. Gutierrez AM, Lou X, Erik A, Persson G, Ring A (2000) Growth hormones reverse desensitization of $\mathrm{P}_{2} \mathrm{Y}_{2}$ receptors in rat mesangial cells. Biochem Biophys Res Commun 270:594-599

123. Hanner F, Sorensen CM, Holstein-Rathlou NH, Peti-Peterdi J (2010) Connexins and the kidney. Am J Physiol Regul Integr Comp Physiol 298:R1143-R1155

124. Hanner F, Lam L, Nguyen MT, Yu A, Peti-Peterdi J (2012) Intrarenal localization of the plasma membrane ATP channel pannexin1. Am J Physiol Ren Physiol 303:F1454-F1459

125. Harada H, Tsukimoto M, Ikari A, Suketa Y (2003) P2X $\mathrm{X}_{7}$ receptorinduced generation of reactive oxygen species in rat mesangial cells. Drug Dev Res 59:112-117

126. Harahap AR, Goding JW (1988) Distribution of the murine plasma cell antigen PC-1 in non-lymphoid tissues. J Immunol 141:23172320

127. Harhun M, Povstyan O, Gordienko D (2009) P2X receptormediated current in myocytes from renal resistance arteries. J Gen Physiol 134:7a

128. Heidemann HT, Müller S, Mertins L, Stepan G, Hoffmann K, Ohnhaus EE (1989) Effect of aminophylline on cisplatin nephrotoxicity in the rat. Br J Pharmacol 97:313-318

129. Heidenreich S, Tepel M, Schlüter H, Harrach B, Zidek W (1995) Regulation of rat mesangial cell growth by diadenosine phosphates. J Clin Invest 95:2862-2867

130. Heyeraas KJ, Aukland K (1987) Interlobular arterial resistance: influence of renal arterial pressure and angiotensin II. Kidney Int 31:1291-1298

131. Hill C, Parker AJ, White SJ (2000) Expression of P2X purinergic receptors in cultured mouse mesangial cells. J Physiol 527:15P-16P

132. Hillman KA, Johnson TM, Winyard PJD, Burnstock G, Unwin RJ, Woolf AS (2002) $\mathrm{P} 2 \mathrm{X}_{7}$ receptors are expressed during mouse nephrogenesis and in collecting duct cysts of the $c p k / c p k$ mouse. Exp Nephrol 10:34-42

133. Hillman KA, Woolf AS, Johnson TM, Wade A, Unwin RJ, Winyard PJ (2004) The $\mathrm{P}_{2} \mathrm{X}_{7}$ ATP receptor modulates renal cyst development in vitro. Biochem Biophys Res Commun 322:434-439

134. Hohenstein B, Renk S, Lang K, Daniel C, Freund M, Léon C, Amann KU, Gachet C, Hugo CP (2007) P2Y1 gene deficiency protects from renal disease progression and capillary rarefaction during passive crescentic glomerulonephritis. J Am Soc Nephrol 18:494-505

135. Holstein-Rathlou NH (1987) Synchronization of proximal intratubular pressure oscillations: evidence for interaction between nephrons. Pflugers Arch 408:438-443

136. Holtzclaw JD, Cornelius RJ, Hatcher LI, Sansom SC (2011) Coupled ATP and potassium efflux from intercalated cells. Am J Physiol Ren Physiol 300:F1319-F1326

137. Hooper KM, Boletta A, Germino GG, Hu Q, Ziegelstein RC, Sutters M (2005) Expression of polycystin-1 enhances endoplasmic reticulum calcium uptake and decreases capacitative calcium entry in ATP-stimulated MDCK cells. Am J Physiol Ren Physiol 289: F521-F530

138. Hovater MB, Olteanu D, Yoder BK, Schwiebert EM (2007) Autocrine purinergic signaling is required for monocilium-driven signaling. FASEB J 21:596.1

139. Hovater MB, Olteanu D, Welty EA, Schwiebert EM (2008) Purinergic signaling in the lumen of a normal nephron and in remodeled PKD encapsulated cysts. Purinergic Signal 4:109-124
140. Hovater MB, Olteanu D, Hanson EL, Cheng NL, Siroky B, Fintha A, Komlosi P, Liu W, Satlin LM, Bell PD, Yoder BK, Schwiebert EM (2008) Loss of apical monocilia on collecting duct principal cells impairs ATP secretion across the apical cell surface and ATPdependent and flow-induced calcium signals. Purinergic Signal 4: $155-170$

141. Hu J, Barr MM (2005) ATP-2 interacts with the PLAT domain of LOV-1 and is involved in Caenorhabditis elegans polycystin signaling. Mol Biol Cell 16:458-469

142. Hughes RJ, Torres B, Zambon A, Arthur D, Bohmann C, Rump LC Insel PA (2003) Expression of multiple P2Y receptors by MDCK-D1 cells: $\mathrm{P} 2 \mathrm{Y}_{1}$ receptor cloning and signaling. Drug Dev Res 59:1-7

143. Huwiler A, Pfeilschifter J (1994) Stimulation by extracellular ATP and UTP of the mitogen-activated protein kinase cascade and proliferation of rat renal mesangial cells. Br J Pharmacol 113:14551463

144. Huwiler A, Wartmann M, van den Bosch H, Pfeilschifter J (2000) Extracellular nucleotides activate the $\mathrm{p} 38$-stress-activated protein kinase cascade in glomerular mesangial cells. Br J Pharmacol 129: 612-618

145. Huwiler A, Rölz W, Dorsch S, Ren S, Pfeilschifter J (2002) Extracellular ATP and UTP activate the protein kinase B/Akt cascade via the $\mathrm{P}_{2} \mathrm{Y}_{2}$ purinoceptor in renal mesangial cells. Br J Pharmacol 136:520-529

146. Inscho EW (2001) P2 receptors in regulation of renal microvascular function. Am J Physiol Ren Physiol 280:F927-F944

147. Inscho EW (2009) Purinoceptor regulation of renal tubular transport is coming of age. Am J Physiol Ren Physiol 297: F1166-F1167

148. Inscho EW (2009) Lewis K. Dahl Memorial Lecture. Mysteries of renal autoregulation. Hypertension 53:299-306

149. Inscho EW, Ohishi K, Navar LG (1992) Effects of ATP on pre- and postglomerular juxtamedullary microvasculature. Am J Physiol 263:F886-F893

150. Inscho EW, Mitchell KD, Navar LG (1994) Extracellular ATP in the regulation of renal microvascular function. FASEB J 8:319-328

151. Inscho EW, Cook AK, Navar LG (1996) Pressure-mediated vasoconstriction of juxtamedullary afferent arterioles involves P2purinoceptor activation. Am J Physiol 271:F1077-F1085

152. Inscho EW, Cook AK, Imig JD, Vial C, Evans RJ (2003) Physiological role for $\mathrm{P}_{2} \mathrm{X}_{1}$ receptors in renal microvascular autoregulatory behavior. J Clin Invest 112:1895-1905

153. Inscho EW, Cook AK, Imig JD, Vial C, Evans RJ (2004) Renal autoregulation in $\mathrm{P}_{2} \mathrm{X}_{1}$ knockout mice. Acta Physiol Scand 181: 445-453

154. Inscho EW, Cook AK, Clarke A, Zhang S, Guan Z (2011) P2X receptor-mediated vasoconstriction of afferent arterioles in angiotensin II-infused hypertensive rats fed a high-salt diet. Hypertension 57:780-787

155. Insel PA, Ostrom RS, Zambon AC, Hughes RJ, Balboa MA, Shehnaz D, Gregorian C, Torres B, Firestein BL, Xing M, Post SR (2001) P2Y receptors of MDCK cells: epithelial cell regulation by extracellular nucleotides. Clin Exp Pharmacol Physiol 28:351354

156. Ishikawa I, Shikura N, Takada K (1993) Amelioration of glycerolinduced acute renal failure in rats by an adenosine $A_{1}$ receptor antagonist (FR-113453). Ren Fail 15:1-5

157. Ishikawa S, Kawasumi M, Kusaka I, Komatsu N, Iwao N, Saito T (1994) Extracellular ATP promotes cellular growth of glomerular mesangial cells mediated via phospholipase C. Biochem Biophys Res Commun 202:234-240

158. Itoh S, Carretero OA, Murray RD (1985) Possible role of adenosine in the macula densa mechanism of renin release in rabbits. J Clin Invest 76:1412-1417

159. Jackson EK (1991) Adenosine: a physiological brake on renin release. Annu Rev Pharmacol Toxicol 31:1-35 
160. Jackson EK (1997) Renal actions of purines. In: Jacobson KA, Jarvis MF (eds) Purinergic approaches in experimental therapeutics. Wiley-Liss, New York, pp 217-250

161. Jackson EK (2001) P1 and P2 receptors in the renal system. In: Abbracchio MP, Williams M (eds) Purinergic and pyrimidinergic signalling II. Springer, Berlin, pp 33-71

162. Jackson EK, Cheng D, Tofovic SP, Mi Z (2012) Endogenous adenosine contributes to renal sympathetic neurotransmission via postjunctional A1 receptor-mediated coincident signaling. Am J Physiol Ren Physiol 302:F466-F476

163. Jalilian I, Spildrejorde M, Seavers A, Curtis BL, McArthur JD, Sluyter R (2012) Functional expression of the damage-associated molecular pattern receptor $\mathrm{P} 2 \mathrm{X} 7$ on canine kidney epithelial cells. Vet Immunol Immunopathol 150:228-233

164. Jan CR, Ho CM, Wu SN, Tseng CJ (1998) Mechanisms of rise and decay of ADP-evoked calcium signal in MDCK cells. Chin J Physiol 41:67-73

165. Jankowski M (2008) Purinergic regulation of glomerular microvasculature and tubular function. J Physiol Pharmacol 59(Suppl 9): 121-135

166. Jankowski M, Szczepanska-Konkel M, Kalinowski L, Angielski S (2001) Cyclic GMP-dependent relaxation of isolated rat renal glomeruli induced by extracellular ATP. J Physiol 530:123-130

167. Jankowski M, Angielski S, Szczepanska-Konkel M (2008) Dissociation between the effects of $\mathrm{P}^{1}, \mathrm{P}^{4}$-diadenosine tetraphosphate $\left(\mathrm{Ap}_{4} \mathrm{~A}\right)$ on renal haemodynamics and tubular function in anaesthetized rats. J Physiol Pharmacol 59:129-137

168. Jankowski M, Szamocka E, Kowalski R, Angielski S, SzczepanskaKonkel M (2011) The effects of P2X receptor agonists on renal sodium and water excretion in anaesthetized rats. Acta Physiol (Oxf) 202:193-201

169. Jankowski V, Karadogan S, Vanholder R, Nofer JR, HergetRosenthal S, van der Giet M, Tölle M, Tran TN, Zidek W, Jankowski J (2007) Paracrine stimulation of vascular smooth muscle proliferation by diadenosine polyphosphates released from proximal tubule epithelial cells. Kidney Int 71:994-1000

170. Jankowski V, Patzak A, Herget-Rosenthal S, Tran TN, Lai EY, Gunthner T, Buschmann I, Zidek W, Jankowski J (2008) Uridine adenosine tetraphosphate acts as an autocrine hormone affecting glomerular filtration rate. J Mol Med 86:333-340

171. Jankowski V, Günthner T, Herget-Rosenthal S, Zidek W, Jankowski J (2009) Dinucleoside polyphosphates and uremia. Semin Dial 22: 396-399

172. Jans D, Srinivas SP, Waelkens E, Segal A, Larivière E, Simaels J, Van Driessche W (2002) Hypotonic treatment evokes biphasic ATP release across the basolateral membrane of cultured renal epithelia (A6). J Physiol 545:543-555

173. Jaramillo-Juárez F, Rodríguez-Vázquez ML, Muñoz-Martínez J, Quezada-Tristán T, Posadas del Río FA, Llamas-Viramontes J, Ortíz GG, Feria-Velasco A, Reyes JL (2005) The ATP levels in kidneys and blood are mainly decreased by acute ingestion of tullidora (Karwinskia humboldtiana). Toxicon 46:99-103

174. Jensen ME, Odgaard E, Christensen MH, Praetorius HA, Leipziger $\mathrm{J}$ (2007) Flow-induced $\left[\mathrm{Ca}^{2+}\right]_{\mathrm{i}}$ increase depends on nucleotide release and subsequent purinergic signaling in the intact nephron. J Am Soc Nephrol 18:2062-2070

175. Jeyaraj SC, Dakhlallah D, Hill SR, Lee BS (2006) Expression and distribution of HuR during ATP depletion and recovery in proximal tubule cells. Am J Physiol Ren Physiol 291:F1255-F1263

176. Ji X, Naito Y, Hirokawa G, Weng H, Hiura Y, Takahashi R, Iwai N (2012) $\mathrm{P} 2 \mathrm{X}_{7}$ receptor antagonism attenuates the hypertension and renal injury in Dahl salt-sensitive rats. Hypertens Res 35:173-179

177. Jian R, Sun Y, Wang Y, Yu J, Zhong L, Zhou P (2012) CD73 protects kidney from ischemia-reperfusion injury through reduction of free radicals. APMIS 120:130-138
178. Jin W, Hopfer U (1997) Purinergic-mediated inhibition of $\mathrm{Na}^{+}-\mathrm{K}^{+}$ATPase in proximal tubule cells: elevated cytosolic $\mathrm{Ca} 2+$ is not required. Am J Physiol 272:C1169-C1177

179. Joseph SM, Buchakjian MR, Dubyak GR (2003) Colocalization of ATP release sites and ecto-ATPase activity at the extracellular surface of human astrocytes. J Biol Chem 278:23331-23342

180. Kalinowski L, Dobrucki LW, Szczepanska-Konkel M, Jankowski M, Martyniec L, Angielski S, Malinski T (2003) Third-generation $\beta$-blockers stimulate nitric oxide release from endothelial cells through ATP efflux: a novel mechanism for antihypertensive action. Circulation 107:2747-2752

181. Kang HS, Kerstan D, Dai LJ, Ritchie G, Quamme GA (2001) Adenosine modulates $\mathrm{Mg}^{2+}$ uptake in distal convoluted tubule cells via $A_{1}$ and $A_{2}$ purinoceptors. Am J Physiol Ren Physiol 281: F1141-F1147

182. Karczewska J, Piwkowska A, Rogacka D, Stepinski J, Angielski S, Jankowski M (2011) Purinergic modulation of glucose uptake into cultured rat podocytes: effect of diabetic milieu. Biochem Biophys Res Commun 404:723-727

183. Kauffenstein G, Drouin A, Thorin-Trescases N, Bachelard H, Robaye B, Orleans-Juste P, Marceau F, Thorin E, Sevigny J (2010) NTPDase1 (CD39) controls nucleotide-dependent vasoconstriction in mouse. Cardiovasc Res 85:204-213

184. Kawabata M, Ogawa T, Takabatake T (1998) Control of rat glomerular microcirculation by juxtaglomerular adenosine A1 receptors. Kidney Int Suppl 67:S228-S230

185. Kempson SA, Edwards JM, Osborn A, Sturek M (2008) Acute inhibition of the betaine transporter by ATP and adenosine in renal MDCK cells. Am J Physiol Ren Physiol 295:F108-F117

186. Kim YH, Choi YJ, Bae HR, Woo JS (2009) P2 Receptor-mediated inhibition of vasopressin-stimulated fluid transport and cAMP responses in AQP2-transfected MDCK cells. Korean J Physiol Pharmacol 13:9-14

187. Kishore BK, Chou CL, Knepper MA (1995) Extracellular nucleotide receptor inhibits AVP-stimulated water permeability in inner medullary collecting duct. Am J Physiol 269:F863-F869

188. Kishore BK, Ginns SM, Krane CM, Nielsen S, Knepper MA (2000) Cellular localization of $\mathrm{P}_{2} \mathrm{Y}_{2}$ purinoceptor in rat renal inner medulla and lung. Am J Physiol Ren Physiol 278:F43-F51

189. Kishore BK, Kran CM, Reif M, Menon AG (2001) Molecular physiology of urinary concentration defect in elderly population. Int Urol Nephrol 33:235-248

190. Kishore BK, Isaac J, Fausther M, Tripp SR, Shi H, Gill PS, Braun N, Zimmermann H, Sévigny J, Robson SC (2005) Expression of NTPDase1 and NTPDase2 in murine kidney: relevance to regulation of P2 receptor signaling. Am J Physiol Ren Physiol 288: F1032-F1043

191. Kishore BK, Krane CM, Miller RL, Shi H, Zhang P, Hemmert A, Sun R, Nelson RD (2005) P2Y2 receptor mRNA and protein expression is altered in inner medullas of hydrated and dehydrated rats: relevance to AVP-independent regulation of IMCD function. Am J Physiol Ren Physiol 288:F1164-F1172

192. Kishore BK, Nelson RD, Miller RL, Carlson NG, Kohan DE (2009) $\mathrm{P}_{2} \mathrm{Y}_{2}$ receptors and water transport in the kidney. Purinergic Signal 5:491-499

193. Klawitter S, Hofmann LP, Pfeilschifter J, Huwiler A (2007) Extracellular nucleotides induce migration of renal mesangial cells by upregulating sphingosine kinase- 1 expression and activity. $\mathrm{Br} \mathrm{J}$ Pharmacol 150:271-280

194. Kleta R, Hirsch J, Heidenreich S, Schlüter H, Zidek W, Schlatter E (1995) Effects of diadenosine polyphosphates, ATP and angiotensin II on membrane voltage and membrane conductances of rat mesangial cells. Pflugers Arch 430:713-720

195. Koltsova SV, Platonova A, Maksimov GV, Mongin AA, Grygorczyk R, Orlov SN (2011) Activation of P2Y receptors 
causes strong and persistent shrinkage of C11-MDCK renal epithelial cells. Am J Physiol Cell Physiol 301:C403-C412

196. Komlosi P, Peti-Peterdi J, Fuson AL, Fintha A, Rosivall L, Bell PD (2004) Macula densa basolateral ATP release is regulated by luminal $[\mathrm{NaCl}]$ and dietary salt intake. Am J Physiol Renal Physiol 286: F1054-F1058

197. Koster HP, Hartog A, van Os CH, Bindels RJ (1996) Inhibition of $\mathrm{Na}^{+}$and $\mathrm{Ca}^{2+}$ reabsorption by $\mathrm{P} 2 \mathrm{u}$ purinoceptors requires $\mathrm{PKC}$ but not $\mathrm{Ca}^{2+}$ signaling. Am J Physiol 270:F53-F60

198. Kottgen M, Buchholz B, Garcia-Gonzalez MA, Kotsis F, Fu X, Doerken M, Boehlke C, Steffl D, Tauber R, Wegierski T, Nitschke R, Suzuki M, Kramer-Zucker A, Germino GG, Watnick T, Prenen J, Nilius B, Kuehn EW, Walz G (2008) TRPP2 and TRPV4 form a polymodal sensory channel complex. J Cell Biol 182:437-447

199. Kowalski R, Kreft E, Kasztan M, Jankowski M, Szczepanska-Konkel M (2012) Chronic renal denervation increases renal tubular response to $\mathrm{P} 2 \mathrm{X}$ receptor agonists in rats: implication for renal sympathetic nerve ablation. Nephrol Dial Transplant 27:3443-3448

200. Kriz W (2004) Adenosine and ATP: traffic regulators in the kidney. J Clin Invest 114:611-613

201. Kuczeriszka M, Dobrowolski L, Walkowska A, Sadowski J, Kompanowska-Jezierska E (2013) Adenosine effects on renal function in the rat: role of sodium intake and cytochrome P450. Nephron Physiol 123:1-5

202. Kulick A, Panico C, Gill P, Welch WJ (2008) Low salt intake increases adenosine type 1 receptor expression and function in the rat proximal tubule. Am J Physiol Ren Physiol 295:F37-F41

203. Kurtz A, Kaissling B, Busse R, Baier W (1991) Endothelial cells modulate renin secretion from isolated mouse juxtaglomerular cells. J Clin Invest 88:1147-1154

204. Labasi JM, Petrushova N, Donovan C, McCurdy S, Lira P, Payette MM, Brissette W, Wicks JR, Audoly L, Gabel CA (2002) Absence of the $\mathrm{P} 2 \mathrm{X}_{7}$ receptor alters leukocyte function and attenuates an inflammatory response. J Immunol 168:6436-6445

205. Lajdova I, Oksa A, Chorvat D Jr, Topor P, Spustova V (2012) Purinergic $\mathrm{P}_{2} \mathrm{X}_{7}$ receptors participate in disturbed intracellular calcium homeostasis in peripheral blood mononuclear cells of patients with chronic kidney disease. Kidney Blood Press Res 35:48-57

206. Lang F, Plöckinger B, Häussinger D, Paulmichl M (1988) Effects of extracellular nucleotides on electrical properties of subconfluent Madin Darby canine kidney cells. Biochim Biophys Acta 943: 471-476

207. Le Hir M, Gandhi R, Dubach UC (1989) Purification and properties of a 5'-nucleotidase from rat renal membranes. Enzyme 41:87-93

208. Lee HT, Ota-Setlik A, Xu H, D'Agati VD, Jacobson MA, Emala CW (2003) A3 adenosine receptor knockout mice are protected against ischemia- and myoglobinuria-induced renal failure. Am J Physiol Ren Physiol 284:F267-F273

209. Lee SJ, Kwon CH, Kim YK (2009) Alterations in membrane transport function and cell viability induced by ATP depletion in primary cultured rabbit renal proximal tubular cells. Korean J Physiol Pharmacol 13:15-22

210. Lee YJ, Park SH, Han HJ (2005) ATP stimulates $\mathrm{Na}^{+}$-glucose cotransporter activity via cAMP and p38 MAPK in renal proximal tubule cells. Am J Physiol Cell Physiol 289:C1268-C1276

211. Lee YJ, Park SH, Jeung TO, Kim KW, Lee JH, Han HJ (2005) Effect of adenosine triphosphate on phosphate uptake in renal proximal tubule cells: involvement of PKC and p38 MAPK. J Cell Physiol 205:68-76

212. Lee YJ, Han HJ (2006) Role of ATP in DNA synthesis of renal proximal tubule cells: involvement of calcium, MAPKs, and CDKs. Am J Physiol Ren Physiol 291:F98-F106

213. Lee YJ, Lee JH, Han HJ (2006) Extracellular adenosine triphosphate protects oxidative stress-induced increase of $\mathrm{p} 21^{\mathrm{WAF} 1 / \mathrm{Cip} 1}$ and $\mathrm{p} 27^{\mathrm{Kip} 1}$ expression in primary cultured renal proximal tubule cells: role of PI3K and Akt signaling. J Cell Physiol 209:802-810

214. Lehrmann H, Thomas J, Kim SJ, Jacobi C, Leipziger J (2002) Luminal $\mathrm{P}_{2} \mathrm{Y}_{2}$ receptor-mediated inhibition of $\mathrm{Na}^{+}$absorption in isolated perfused mouse CCD. J Am Soc Nephrol 13:10-18

215. Leipziger J (2003) Control of epithelial transport via luminal P2 receptors. Am J Physiol Ren Physiol 284:F419-F432

216. Leipziger $J$ (2011) Luminal nucleotides are tonic inhibitors of renal tubular transport. Curr Opin Nephrol Hypertens 20:518-522

217. Leipziger J, Bailey MA, Unwin RJ (2003) Purinergic (P2) receptors in the Kidney. Curr Top Membr 54:36-394

218. Lewis CJ, Evans RJ (2001) P2X receptor immunoreactivity in different arteries from the femoral, pulmonary, cerebral, coronary and renal circulations. J Vasc Res 38:332-340

219. Li L, Jeanette Lynch I, Zheng W, Cash MN, Teng X, Wingo CS, Verlander JW, Xia SL (2007) Apical P2XR contribute to $\left[\mathrm{Ca}^{2+}\right]_{i}$ signaling and $I_{\mathrm{sc}}$ in mouse renal MCD. Biochem Biophys Res Commun 359:438-444

220. Li L, Wingo CS, Xia SL (2007) Downregulation of SGK1 by nucleotides in renal tubular epithelial cells. Am J Physiol Ren Physiol 293:F1751-F1757

221. Li L, Huang L, Ye H, Song SP, Bajwa A, Lee SJ, Moser EK, Jaworska K, Kinsey GR, Day YJ, Linden J, Lobo PI, Rosin DL, Okusa MD (2012) Dendritic cells tolerized with adenosine $A_{2} A R$ agonist attenuate acute kidney injury. J Clin Invest 122:3931-3942

222. Li L, Lai EY, Huang Y, Eisner C, Mizel D, Wilcox CS, Schnermann J (2012) Renal afferent arteriolar and tubuloglomerular feedback reactivity in mice with conditional deletions of adenosine 1 receptors. Am J Physiol Ren Physiol 303:F1166-F1175

223. Liclican EL, McGiff JC, Pedraza PL, Ferreri NR, Falck JR, Carroll MA (2005) Exaggerated response to adenosine in kidneys from high salt-fed rats: role of epoxyeicosatrienoic acids. Am J Physiol Ren Physiol 289:F386-F392

224. Lieberthal W, Menza SA, Levine JS (1998) Graded ATP depletion can cause necrosis or apoptosis of cultured mouse proximal tubular cells. Am J Physiol 274:F315-F327

225. Listhrop R, Nelson R, Ecelbarger CA, Kohan DE, Kishore B (2007) Genetic deletion of $\mathrm{P} 2 \mathrm{Y} 2$ receptor $(\mathrm{P} 2 \mathrm{Y} 2-\mathrm{R})$ alters the protein abundances of renal sodium transporters and channels. FASEB J 21:A1328

226. Liu R, Persson AE (2002) Effects of nitric oxide on P2Y receptor resensitization in spontaneously hypertensive rat mesangial cells. $\mathrm{J}$ Hypertens 20:1835-1842

227. Liu R, Gutierrez AM, Ring A, Persson AE (2002) Nitric oxide induces resensitization of $\mathrm{P} 2 \mathrm{Y}$ nucleotide receptors in cultured rat mesangial cells. J Am Soc Nephrol 13:313-321

228. Liu ZX, Nickel CH, Cantley LG (2001) HGF promotes adhesion of ATP-depleted renal tubular epithelial cells in a MAPK-dependent manner. Am J Physiol Ren Physiol 281:F62-F70

229. Locovei S, Wang J, Dahl G (2006) Activation of pannexin 1 channels by ATP through $\mathrm{P} 2 \mathrm{Y}$ receptors and by cytoplasmic calcium. FEBS Lett 580:239-244

230. Loesch A, Unwin R, Gandhi V, Burnstock G (2009) Sympathetic nerve varicosities in close apposition with basolateral membranes of collecting duct epithelial cells of rat kidney. Nephron Physiol 113: $15-21$

231. Lu Y, Ge Y, Manning RD Jr (2011) Expression and function of adenosine $\mathrm{A}_{3}$ receptor in the afferent arteriole. Hypertens 58:E139

232. Ma HP, Li L, Zhou ZH, Eaton DC, Warnock DG (2002) ATP masks stretch activation of epithelial sodium channels in A6 distal nephron cells. Am J Physiol Ren Physiol 282: F501-F505

233. Ma HP, Chou CF, Wei SP, Eaton DC (2007) Regulation of the epithelial sodium channel by phosphatidylinositides: experiments, implications, and speculations. Pflugers Arch 455:169-180 
234. Macala LJ, Hayslett JP (2002) Basolateral and apical A1 adenosine receptors mediate sodium transport in cultured renal epithelial (A6) cells. Am J Physiol Ren Physiol 283:F1216-F1225

235. MacLaughlin M, Martinez-Salgado C, Eleno N, Olivera A, LopezNovoa JM (1997) Adenosine activates mesangial cell proliferation. Cell Signal 9:59-63

236. Mamenko M, Zaika O, Jin M, O’Neil RG, Pochynyuk O (2011) Purinergic activation of $\mathrm{Ca}^{2+}$-permeable TRPV4 channels is essential for mechano-sensitivity in the aldosterone-sensitive distal nephron. PLoS One 6:e22824

237. Marques RD, de Bruijn PI, Sorensen MV, Bleich M, Praetorius HA, Leipziger J (2012) Basolateral P2X receptors mediate inhibition of $\mathrm{NaCl}$ transport in mouse medullary thick ascending limb (mTAL). Am J Physiol Ren Physiol 302:F487-F494

238. McCoy DE, Taylor AL, Kudlow BA, Karlson K, Slattery MJ, Schwiebert LM, Schwiebert EM, Stanton BA (1999) Nucleotides regulate $\mathrm{NaCl}$ transport in mIMCD-K2 cells via $\mathrm{P} 2 \mathrm{X}$ and $\mathrm{P} 2 \mathrm{Y}$ purinergic receptors. Am J Physiol 277:F552-F559

239. McCulloch F, Chambrey R, Eladari D, Peti-Peterdi J (2005) Localization of connexin 30 in the luminal membrane of cells in the distal nephron. Am J Physiol Ren Physiol 289:F1304-F1312

240. McKinney TD, Hosford MA (1993) ATP-stimulated tetraethylammonium transport by rabbit renal brush border membrane vesicles. J Biol Chem 268:6886-6895

241. McLaughlin GE, Alva MD, Egea M (2006) Adenosine receptor antagonism in acute tacrolimus toxicity. Nephrol Dial Transplant 21:1961-1965

242. Menzies RI, Unwin RJ, Dash RK, Beard DA, Cowley AW, Jr., Carlson BE, Mullins JJ, Bailey MA (2013) Effect of P2X4 and $\mathrm{P} 2 \mathrm{X} 7$ receptor antagonism on the pressure diuresis relationship in rats. Front Physiol 4:305

243. Middleton JP, Mangel AW, Basavappa S, Fitz JG (1993) Nucleotide receptors regulate membrane ion transport in renal epithelial cells. Am J Physiol 264:F867-F873

244. Migita K, Lu L, Zhao Y, Honda K, Iwamoto T, Kita S, Katsuragi T (2005) Adenosine induces ATP release via an inositol 1,4,5-trisphosphate signaling pathway in MDCK cells. Biochem Biophys Res Commun 328:1211-1215

245. Migita K, Zhao Y, Katsuragi T (2007) Mitochondria play an important role in adenosine-induced ATP release from Madin-Darby canine kidney cells. Biochem Pharmacol 73:1676-1682

246. Mironova E, Peti-Peterdi J, Bugaj V, Stockand JD (2011) Diminished paracrine regulation of the epithelial $\mathrm{Na}^{+}$channel by purinergic signaling in mice lacking connexin 30 . J Biol Chem 286: 1054-1060

247. Mo J, Fisher MJ (2002) Uridine nucleotide-induced stimulation of gluconeogenesis in isolated rat proximal tubules. Naunyn Schmiedebergs Arch Pharmacol 366:151-157

248. Modlinger PS, Welch WJ (2003) Adenosine A1 receptor antagonists and the kidney. Curr Opin Nephrol Hypertens 12:497-502

249. Mohaupt MG, Fischer T, Schwöbel J, Sterzel RB, Schulze-Lohoff E (1998) Activation of purinergic P2Y2 receptors inhibits inducible NO synthase in cultured rat mesangial cells. Am J Physiol 275: F103-F110

250. Mori M, Nishizaki T, Kawahara K, Okada Y (1996) ATP-activated cation conductance in a Xenopus renal epithelial cell line. J Physiol 491:281-290

251. Mori M, Hosomi H, Nishizaki T, Kawahara K, Okada Y (1997) Calcium release from intracellular stores evoked by extracellular ATP in a Xenopus renal epithelial cell line. J Physiol 502:365-373

252. Murray RD, Churchill PC (1984) Effects of adenosine receptor agonists in the isolated, perfused rat kidney. Am J Physiol 247: H343-H348

253. Nagashima K, Kusaka H, Sato K, Karasawa A (1994) Effects of $\mathrm{KW}-3902$, a novel adenosine $\mathrm{A}_{1}$-receptor antagonist, on cephaloridine-induced acute renal failure in rats. Jpn J Pharmacol 64:9-17

254. Nanoff C, Freissmuth M, Tuisl E, Schütz W (1990) $\mathrm{P}_{2^{-}}$, but not $\mathrm{P}_{1}$-purinoceptors mediate formation of 1,4,5-inositol trisphosphate and its metabolites via a pertussis toxin-insensitive pathway in the rat renal cortex. Br J Pharmacol 100:63-68

255. Navar LG, Bell PD (2004) Romancing the macula densa at UAB. Kidney Int Suppl S34-S40

256. Navar LG, Inscho EW, Majid SA, Imig JD, Harrison-Bernard LM, Mitchell KD (1996) Paracrine regulation of the renal microcirculation. Physiol Rev 76:425-536

257. Nilius B, Sehrer J, Heinke S, Droogmans G (1995) $\mathrm{Ca}^{2+}$ release and activation of $\mathrm{K}^{+}$and $\mathrm{Cl}^{-}$currents by extracellular ATP in distal nephron epithelial cells. Am J Physiol 269:C376-C384

258. Nishiyama A, Navar LG (2002) ATP mediates tubuloglomerular feedback. Am J Physiol Regul Integr Comp Physiol 283:R273R275

259. Nishiyama A, Abe Y (2003) Potential roles of interstitial fluid adenosine in the regulation of renal hemodynamics. Biogenic Amines 17:459-474

260. Nishiyama A, Majid DS, Walker M III, Miyatake A, Navar LG (2001) Renal interstitial ATP responses to changes in arterial pressure during alterations in tubuloglomerular feedback activity. Hypertension 37:753-759

261. Nishiyama A, Rahman M, Inscho EW (2004) Role of interstitial ATP and adenosine in the regulation of renal hemodynamics and microvascular function. Hypertens Res 27:791-804

262. Noji T, Sato H, Sano J, Nishikawa S, Kusaka H, Karasawa A (2002) Treatment with an adenosine uptake inhibitor attenuates glomerulonephritis in mice. Eur J Pharmacol 449:293-300

263. O'Connor PM, Cowley AW Jr (2012) Medullary thick ascending limb buffer vasoconstriction of renal outer-medullary vasa recta in salt-resistant but not salt-sensitive rats. Hypertension 60:965-972

264. Odgaard E, Praetorius HA, Leipziger J (2009) AVPstimulated nucleotide secretion in perfused mouse medullary thick ascending limb and cortical collecting duct. J Med Invest 56(Suppl):262-263

265. Olivera A, Lopez-Novoa JM (1992) Effect of adenosine and adenosine analogues on cyclic AMP accumulation in cultured mesangial cells and isolated glomeruli of the rat. Br J Pharmacol 107:341-346

266. Olivetti G, Anversa P, Melissari M, Loud AV (1980) Morphometry of the renal corpuscle during postnatal growth and compensatory hypertrophy. Kidney Int 17:438-454

267. Olteanu D, Hovater MB, Schwiebert EM (2007) Intraluminal autocrine purinergic signaling within cysts: implications for the progression of diseases that involve encapsulated cyst formation. Am J Physiol Ren Physiol 292:F11-F14

268. Orth SR, Amann K, Strojek K, Ritz E (2001) Sympathetic overactivity and arterial hypertension in renal failure. Nephrol Dial Transplant 16(Suppl 1):67-69

269. Ortiz PA, Hong NJ, Garvin JL (2001) NO decreases thick ascending limb chloride absorption by reducing $\mathrm{Na}^{+}-\mathrm{K}^{+}-2 \mathrm{Cl}^{-}$cotransporter activity. Am J Physiol Ren Physiol 281:F819-F825

270. Ortiz PA, Hong NJ, Garvin JL (2004) Luminal flow induces eNOS activation and translocation in the rat thick ascending limb. Am J Physiol Ren Physiol 287:F274-F280

271. Ortiz-Capisano MC, Mendez M, Ortiz PA, Beierwaltes WH (2011) Adenosine 1 receptors are expressed by juxtaglomerular cells and interact with calcium signaling to decrease renin release. FASEB J $25: 824$

272. Osmond DA, Inscho EW (2010) P2X 1 receptor blockade inhibits whole kidney autoregulation of renal blood flow in vivo. Am J Physiol Ren Physiol 298:F1360-F1368

273. Osswald H (1984) The role of adenosine in the regulation of glomerular filtration rate and renin secretion. Trends Pharmacol Sci 5:94-97 
274. Osswald H, Schmitz HJ, Kemper R (1978) Renal action of adenosine: effect on renin secretion in the rat. Naunyn Schmiedebergs Arch Pharmacol 303:95-99

275. Ostrom RS, Gregorian C, Insel PA (2000) Cellular release of and response to ATP as key determinants of the set-point of signal transduction pathways. J Biol Chem 275:11735-11739

276. Ostrom RS, Gregorian C, Drenan RM, Gabot K, Rana BK, Insel PA (2001) Key role for constitutive cyclooxygenase-2 of MDCK cells in basal signaling and response to released ATP. Am J Physiol Cell Physiol 281:C524-C531

277. Palygin O, Levchenko V, Ilatovskaya DV, Pavlov TS, Ryan RP, Cowley AW Jr, Staruschenko A (2013) Real-time electrochemical detection of ATP and $\mathrm{H}_{2} \mathrm{O}_{2}$ release in freshly isolated kidneys. Am J Physiol Ren Physiol 305:F134-F141

278. Panico C, Luo Z, Welch WJ (2011) Inhibition of adenosine type 2 receptors increases fluid uptake in the proximal tubule. FASEB J 25: 665

279. Patel A, Honoré E (2010) Polycystins and renovascular mechanosensory transduction. Nat Rev Nephrol 6:530-538

280. Paulais M, Baudouin-Legros M, Teulon J (1995) Extracellular ATP and UTP trigger calcium entry in mouse cortical thick ascending limbs. Am J Physiol 268:F496-F502

281. Paulmichl M, Pfeilschifter J, Wöll E, Lang F (1991) Cellular mechanisms of ATP-induced hyperpolarization in renal epitheloid MDCK-cells. J Cell Physiol 147:68-75

282. Pavenstädt H, Gloy J, Leipziger J, Klär B, Pfeilschifter J, Schollmeyer P, Greger R (1993) Effect of extracellular ATP on contraction, cytosolic calcium activity, membrane voltage and ion currents of rat mesangial cells in primary culture. Br J Pharmacol 109:953-959

283. Pavenstädt H, Ruh J, Greger R, Schollmeyer P (1994) Adenosineinduced hyperpolarization of the membrane voltage in rat mesangial cells in primary culture. Br J Pharmacol 113:7-12

284. Pellerin I, Leclerc M, Claveau D, Mailloux J, Brunette MG (2001) Roles of ATP and cytoskeleton in the regulation of $\mathrm{Na}^{+} / \mathrm{H}^{+}$exchanger along the nephron luminal membrane. J Cell Physiol 187:109116

285. Peti-Peterdi J (2006) Calcium wave of tubuloglomerular feedback. Am J Physiol Ren Physiol 291:F473-F480

286. Pfeilschifter J (1990) Comparison of extracellular ATP and UTP signalling in rat renal mesangial cells. Biochem J 272: 469-472

287. Piwkowska A, Rogacka D, Jankowski M, Angielski S (2011) Extracellular ATP through P2 receptors activates AMP-activated protein kinase and suppresses superoxide generation in cultured mouse podocytes. Exp Cell Res 317:1904-1913

288. Pochynyuk O, Bugaj V, Stockand JD (2008) Physiologic regulation of the epithelial sodium channel by phosphatidylinositides. Curr Opin Nephrol Hypertens 17:533-540

289. Pochynyuk O, Bugaj V, Vandewalle A, Stockand JD (2008) Purinergic control of apical plasma membrane $\mathrm{PI}(4,5) \mathrm{P}_{2}$ levels sets $\mathrm{ENaC}$ activity in principal cells. Am J Physiol Ren Physiol 294: F38-F46

290. Pochynyuk O, Bugaj V, Rieg T, Insel PA, Mironova E, Vallon V, Stockand JD (2008) Paracrine regulation of the epithelial $\mathrm{Na}^{+}$ channel in the mammalian collecting duct by purinergic $\mathrm{P}_{2} \mathrm{Y}_{2}$ receptor tone. J Biol Chem 283:36599-36607

291. Pochynyuk O, Rieg T, Bugaj V, Schroth J, Fridman A, Boss GR, Insel PA, Stockand JD, Vallon V (2010) Dietary $\mathrm{Na}^{+}$ inhibits the open probability of the epithelial sodium channel in the kidney by enhancing apical $\mathrm{P}_{2} \mathrm{Y}_{2}$-receptor tone. FASEB J 24:2056-2065

292. Poelstra K, Heynen ER, Baller JF, Hardonk MJ, Bakker WW (1992) Modulation of anti-Thy1 nephritis in the rat by adenine nucleotides. Evidence for an anti-inflammatory role for nucleotidases. Lab Invest 66:555-563
293. Ponnusamy M, Ma L, Gong R, Pang M, Chin YE, Zhuang S (2011) $\mathrm{P}_{2} \mathrm{X}_{7}$ receptors mediate deleterious renal epithelial-fibroblast cross talk. Am J Physiol Ren Physiol 300:F62-F70

294. Ponnusamy M, Liu N, Gong R, Yan H, Zhuang S (2011) ERK pathway mediates $\mathrm{P} 2 \mathrm{X} 7$ expression and cell death in renal interstitial fibroblasts exposed to necrotic renal epithelial cells. Am J Physiol Ren Physiol 301:F650-F659

295. Post SR, Rump LC, Zambon A, Hughes RJ, Buda MD, Jacobson JP, Kao CC, Insel PA (1998) ATP activates cAMP production via multiple purinergic receptors in MDCK-D1 epithelial cells. Blockade of an autocrine/paracrine pathway to define receptor preference of an agonist. J Biol Chem 273:23093-23097

296. Praetorius HA, Leipziger J (2009) Released nucleotides amplify the cilium-dependent, flow-induced $\left[\mathrm{Ca}^{2+}\right]_{\mathrm{i}}$ response in MDCK cells. Acta Physiol (Oxf) 197:241-251

297. Praetorius HA, Leipziger J (2010) Intrarenal purinergic signaling in the control of renal tubular transport. Annu Rev Physiol 72:377-393

298. Praetorius HA, Leipziger J (2013) Primary cilium-dependent sensing of urinary flow and paracrine purinergic signaling. Semin Cell Dev Biol 24:3-10

299. Praetorius HA, Frøkiaer J, Leipziger J (2005) Transepithelial pressure pulses induce nucleotide release in polarized MDCK cells. Am J Physiol Ren Physiol 288:F133-F141

300. Qu LP, Xue H, Yuan P, Zhou L, Yao T, Huang Y, Lu LM (2009) Adenosine 5'-triphosphate stimulates the increase of TGF- $\beta 1$ in rat mesangial cells under high-glucose conditions via reactive oxygen species and ERK1/2. Acta Pharmacol Sin 30:1601-1606

301. Quezada C, Alarcón S, Jaramillo C, Muñoz D, Oyarzún C, San Martín R (2013) Targeting adenosine signaling to treatment of diabetic nephropathy. Curr Drug Targets 14:490-496

302. Rajagopal M, Pao AC (2010) Adenosine activates AS2b receptors and enhances chloride secretion in kidney inner medullary collecting duct cells. Hypertension 55:1123-1128

303. Rajagopal M, Kathpalia PP, Thomas SV, Pao AC (2011) Activation of $\mathrm{P} 2 \mathrm{Y}_{1}$ and $\mathrm{P} 2 \mathrm{Y}_{2}$ receptors induces chloride secretion via calciumactivated chloride channels in kidney inner medullary collecting duct cells. Am J Physiol Ren Physiol 301:F544-F553

304. Rajagopal M, Kathpalia PP, Widdicombe JH, Pao AC (2012) Differential effects of extracellular ATP on chloride transport in cortical collecting duct cells. Am J Physiol Ren Physiol 303: F483-F491

305. Rajakumar SV, Lu B, Crikis S, Robson SC, d'Apice AJ, Cowan PJ, Dwyer KM (2010) Deficiency or inhibition of CD73 protects in mild kidney ischemia-reperfusion injury. Transplantation 90:1260-1264

306. Ren J, Mi Z, Jackson EK (2008) Assessment of nerve stimulationinduced release of purines from mouse kidneys by tandem mass spectrometry. J Pharmacol Exp Ther 325:920-926

307. Ren Y, Carretero OA, Garvin JL (2002) Role of mesangial cells and gap junctions in tubuloglomerular feedback. Kidney Int 62:525-531

308. Rieg T, Vallon V (2009) ATP and adenosine in the local regulation of water transport and homeostasis by the kidney. Am J Physiol Regul Integr Comp Physiol 296:R419-R427

309. Rieg T, Bundey RA, Chen Y, Deschenes G, Junger W, Insel PA, Vallon V (2007) Mice lacking $\mathrm{P}_{2} \mathrm{Y}_{2}$ receptors have salt-resistant hypertension and facilitated renal $\mathrm{Na}+$ and water reabsorption. FASEB J 21:3717-3726

310. Rieg T, Gerasimova M, Boyer JL, Insel PA, Vallon V (2011) P2 $\mathrm{Y}_{2}$ receptor activation decreases blood pressure and increases renal $\mathrm{Na}^{+}$ excretion. Am J Physiol Regul Integr Comp Physiol 301:R510-R518

311. Rivera I, Zhang S, Fuller BS, Edwards B, Seki T, Wang MH, Marrero MB, Inscho EW (2007) P2 receptor regulation of $\left[\mathrm{Ca}^{2+}\right]_{\mathrm{i}}$ in cultured mouse mesangial cells. Am J Physiol Ren Physiol 292: F1380-F1389

312. Robson L, Hunter M (1997) Two $\mathrm{K}^{+}$-selective conductances in single proximal tubule cells isolated from frog kidney are regulated by ATP. J Physiol 500:605-616 
313. Rost S, Daniel C, Schulze-Lohoff E, Bäumert HG, Lambrecht G, Hugo C (2002) P2 receptor antagonist PPADS inhibits mesangial cell proliferation in experimental mesangial proliferative glomerulonephritis. Kidney Int 62:1659-1671

314. Rouse D, Leite M, Suki WN (1994) ATP inhibits the hydrosmotic effect of AVP in rabbit CCT: evidence for a nucleotide $\mathrm{P}_{2 \mathrm{u}}$ receptor. Am J Physiol 267:F289-F295

315. Rubera I, Tauc M, Bidet M, Verheecke-Mauze C, De Renzis G, Poujeol C, Cuiller B, Poujeol P (2000) Extracellular ATP increases $\left[\mathrm{Ca}^{2+}\right]_{\mathrm{i}}$ in distal tubule cells. II. Activation of $\mathrm{Ca}^{2+}$-dependent $\mathrm{Cl}^{-}$ conductance. Am J Physiol Ren Physiol 279:F102-F111

316. Rubera I, Barrière H, Tauc M, Bidet M, Verheecke-Mauze C, Poujeol C, Cuiller B, Poujeol P (2001) Extracellular adenosine modulates a volume-sensitive-like chloride conductance in immortalized rabbit DC1 cells. Am J Physiol Ren Physiol 280:F126-F145

317. Scemes E, Spray DC, Meda P (2009) Connexins, pannexins, innexins: novel roles of "hemi-channels". Pflugers Arch 457: 1207-1226

318. Schlatter E, Ankorina I, Haxelmans S, Kleta R (1995) Effects of diadenosine polyphosphates, ATP and angiotensin II on cytosolic $\mathrm{Ca}^{2+}$ activity and contraction of rat mesangial cells. Pflugers Arch 430:721-728

319. Schnermann J (2011) Maintained tubuloglomerular feedback responses during acute inhibition of $\mathrm{P} 2$ purinergic receptors in mice. Am J Physiol Ren Physiol 300:F339-F344

320. Schnermann J, Levine DZ (2003) Paracrine factors in tubuloglomerular feedback: adenosine, ATP, and nitric oxide. Annu Rev Physiol 65:501-529

321. Schnermann J, Briggs JP (2008) Tubuloglomerular feedback: mechanistic insights from gene-manipulated mice. Kidney Int 74:418426

322. Scholz-Pedretti K, Pfeilschifter J, Kaszkin M (2001) Potentiation of cytokine induction of group IIA phospholipase $\mathrm{A}_{2}$ in rat mesangial cells by ATP and adenosine via the A2A adenosine receptor. Br J Pharmacol 132:37-46

323. Schulze-Lohoff E, Zanner S, Ogilvie A, Sterzel RB (1992) Extracellular ATP stimulates proliferation of cultured mesangial cells via $\mathrm{P}_{2}$-purinergic receptors. Am J Physiol 263:F374-F383

324. Schulze-Lohoff E, Schagerl S, Ogilvie A, Sterzel RB (1995) Extracellular ATP augments mesangial cell growth induced by multiple growth factors. Nephrol Dial Transplant 10:2027-2034

325. Schulze-Lohoff E, Zanner S, Ogilvie A, Sterzel RB (1995) Vasoactive diadenosine polyphosphates promote growth of cultured renal mesangial cells. Hypertension 26:899-904

326. Schulze-Lohoff E, Hugo C, Rost S, Arnold S, Gruber A, Brüne B, Sterzel RB (1998) Extracellular ATP causes apoptosis and necrosis of cultured mesangial cells via $\mathrm{P} 2 \mathrm{Z} / \mathrm{P} 2 \mathrm{X}_{7}$ receptors. Am J Physiol 275:F962-F971

327. Schweda F, Segerer F, Castrop H, Schnermann J, Kurtz A (2005) Blood pressure-dependent inhibition of renin secretion requires A1 adenosine receptors. Hypertension 46:780-786

328. Schwiebert EM (2001) ATP release mechanisms, ATP receptors and purinergic signalling along the nephron. Clin Exp Pharmacol Physiol 28:340-350

329. Schwiebert EM, Wallace DP, Braunstein GM, King SR, Peti-Peterdi J, Hanaoka K, Guggino WB, Guay-Woodford LM, Bell PD, Sullivan LP, Grantham JJ, Taylor AL (2002) Autocrine extracellular purinergic signaling in epithelial cells derived from polycystic kidneys. Am J Physiol Ren Physiol 282:F763-F775

330. Shaik ZP, Fifer EK, Nowak G (2007) Protein kinase B/Akt modulates nephrotoxicant-induced necrosis in renal cells. Am J Physiol Ren Physiol 292:F292-F303

331. Shaver SR, Rideout JL, Pendergast W, Douglass JG, Brown EG, Boyer JL, Patel RI, Redick CC, Jones AC, Picher M, Yerxa BR (2005) Structure-activity relationships of dinucleotides: potent and selective agonists of P2Y receptors. Purinergic Signal 1:183-191
332. Shirley DG, Bailey MA, Unwin RJ (2005) In vivo stimulation of apical P2 receptors in collecting ducts: evidence for inhibition of sodium reabsorption. Am J Physiol Ren Physiol 288:F1243-F1248

333. Shirley DG, Vekaria RM, Sévigny J (2009) Ectonucleotidases in the kidney. Purinergic Signal 5:501-511

334. Shrivastava AN, Triller A, Sieghart W, Sarto-Jackson I (2011) Regulation of $\mathrm{GABA}_{\mathrm{A}}$ receptor dynamics by interaction with purinergic $\mathrm{P}_{2} \mathrm{X}_{2}$ receptors. J Biol Chem 286:14455-14468

335. Siegel NJ, Glazier WB, Chaudry IH, Gaudio KM, Lytton B, Baue AE, Kashgarian M (1980) Enhanced recovery from acute renal failure by the postischemic infusion of adenine nucleotides and magnesium chloride in rats. Kidney Int 17:338-349

336. Siegel NJ, Avison MJ, Reilly HF, Alger JR, Shulman RG (1983) Enhanced recovery of renal ATP with postischemic infusion of ATP- $\mathrm{MgCl}_{2}$ determined by 31P-NMR. Am J Physiol 245:F530F534

337. Silva GB, Garvin JL (2008) TRPV4 mediates hypotonicity-induced ATP release by the thick ascending limb. Am J Physiol Ren Physiol 295:F1090-F1095

338. Silva GB, Garvin JL (2009) Akt1 mediates purinergic-dependent NOS3 activation in thick ascending limbs. Am J Physiol Ren Physiol 297:F646-F652

339. Silva GB, Garvin JL (2009) Extracellular ATP inhibits transport in medullary thick ascending limbs: role of $\mathrm{P} 2 \mathrm{X}$ receptors. Am J Physiol Ren Physiol 297:F1168-F1173

340. Silva GB, Beierwaltes WH, Garvin JL (2006) Extracellular ATP stimulates NO production in rat thick ascending limb. Hypertension 47:563-567

341. Simmons NL (1981) Identification of a purine $\left(\mathrm{P}_{2}\right)$ receptor linked to ion transport in a cultured renal (MDCK) epithelium. $\mathrm{Br} \mathrm{J}$ Pharmacol 73:379-384

342. Sipos A, Vargas SL, Toma I, Hanner F, Willecke K, PetiPeterdi J (2009) Connexin 30 deficiency impairs renal tubular ATP release and pressure natriuresis. J Am Soc Nephrol 20:1724-1732

343. Skøtt O, Baumbach L (1985) Effects of adenosine on renin release from isolated rat glomeruli and kidney slices. Pflugers Arch 404: 232-237

344. Smith JA, Whitaker EM, Bowmer CJ, Yates MS (2000) Differential expression of renal adenosine $A_{1}$ receptors induced by acute renal failure. Biochem Pharmacol 59:727-732

345. Smith JA, Sivaprasadarao A, Munsey TS, Bowmer CJ, Yates MS (2001) Immunolocalisation of adenosine $A_{1}$ receptors in the rat kidney. Biochem Pharmacol 61:237-244

346. Solini A, Iacobini C, Ricci C, Chiozzi P, Amadio L, Pricci F, Di MU, Di Virgilio F, Pugliese G (2005) Purinergic modulation of mesangial extracellular matrix production: role in diabetic and other glomerular diseases. Kidney Int 67:875885

347. Solini A, Santini E, Chimenti D, Chiozzi P, Pratesi F, Cuccato S, Falzoni S, Lupi R, Ferrannini E, Pugliese G, Di Virgilio F (2007) Multiple $\mathrm{P} 2 \mathrm{X}$ receptors are involved in the modulation of apoptosis in human mesangial cells: evidence for a role of $\mathrm{P} 2 \mathrm{X}_{4}$. Am J Physiol Ren Physiol 292:F1537-F1547

348. Souza-Menezes J, Morales M (2009) CFTR structure and function: is there a role in the kidney? Biophys Rev 1:3-12

349. Spielman WS, Arend LJ (1991) Adenosine receptors and signaling in the kidney. Hypertension 17:117-130

350. Stefanovic V, Vlahovic $P$ (1995) $A_{2}$ adenosine receptors in human glomerular mesangial cells. Experientia 51:360-362

351. Steinhausen M, Blum M, Fleming JT, Holz FG, Parekh N, Wiegman DL (1989) Visualization of renal autoregulation in the split hydronephrotic kidney of rats. Kidney Int 35:11511160

352. Stewart GS, Glanville M, Aziz O, Simmons NL, Gray MA (2001) Regulation of an outwardly rectifying chloride conductance in renal 
epithelial cells by external and internal calcium. J Membr Biol 180: 49-64

353. Stiepanow-Trzeciak A, Jankowski M, Angielski S, SzczepanskaKonkel M (2007) P1, P4-diadenosine tetraphosphate (Ap4A) inhibits proximal tubular reabsorption of sodium in rats. Nephron Physiol 106:13-18

354. Stockand JD, Mironova E, Bugaj V, Rieg T, Insel PA, Vallon V, PetiPeterdi J, Pochynyuk O (2010) Purinergic inhibition of ENaC produces aldosterone escape. J Am Soc Nephrol 21:1903-1911

355. Sumpio BE, Chaudry IH, Baue AE (1985) Reduction of the druginduced nephrotoxicity by $\mathrm{ATP}-\mathrm{MgCl}_{2}$. 1 . Effects on the cisdiamminedichloroplatinum-treated isolated perfused kidneys. J Surg Res 38:429-437

356. Sun D, Samuelson LC, Yang T, Huang Y, Paliege A, Saunders T, Briggs J, Schnermann J (2001) Mediation of tubuloglomerular feedback by adenosine: evidence from mice lacking adenosine 1 receptors. Proc Natl Acad Sci U S A 98:9983-9988

357. Sun R, Carlson NG, Hemmert AC, Kishore BK (2005) P2Y ${ }_{2}$ receptor-mediated release of prostaglandin $\mathrm{E}_{2}$ by IMCD is altered in hydrated and dehydrated rats: relevance to AVP-independent regulation of IMCD function. Am J Physiol Ren Physiol 289: F585-F592

358. Suzuki F, Shimada J, Mizumoto H, Karasawa A, Kubo K, Nonaka H, Ishii A, Kawakita T (1992) Adenosine $A_{1}$ antagonists. 2. Structure-activity relationships on diuretic activities and protective effects against acute renal failure. J Med Chem 35:3066-3075

359. Szczepanska-Konkel M, Jankowski M, Stiepanow-Trzeciak A, Angielski S (2005) Effects of diadenosine polyphosphates on glomerular volume. Br J Pharmacol 144:1109-1117

360. Takeda M, Yoshitomi K, Imai M (1993) Regulation of $\mathrm{Na}^{+}-3 \mathrm{HCO}_{3}{ }^{-}$ cotransport in rabbit proximal convoluted tubule via adenosine $\mathrm{A}_{1}$ receptor. Am J Physiol 265:F511-F519

361. Takeda M, Kawamura T, Kobayashi M, Endou H (1996) ATPinduced calcium mobilization in glomerular mesangial cells is mediated by $\mathrm{P}_{2 \mathrm{U}}$ purinoceptor. Biochem Mol Biol Int 39:1193-1200

362. Takenaka T, Hayashi K, Ikenaga H (2004) Blood pressure regulation and renal microcirculation. Contrib Nephrol 143: 46-64

363. Takenaka T, Okada H, Kanno Y, Inoue T, Ryuzaki M, Nakamoto H, Kawachi H, Shimizu F, Suzuki H (2006) Exogenous 5'-nucleotidase improves glomerular autoregulation in Thy-1 nephritic rats. Am J Physiol Ren Physiol 290:F844-F853

364. Takenaka T, Inoue T, Kanno Y, Okada H, Hill CE, Suzuki H (2008) Connexins 37 and 40 transduce purinergic signals mediating renal autoregulation. Am J Physiol Regul Integr Comp Physiol 294:R1-R11

365. Tamura Y, Tanabe K, Kitagawa W, Uchida S, Schreiner GF, Johnson RJ, Nakagawa T (2012) Nicorandil, a $K_{\text {atp }}$ channel opener, alleviates chronic renal injury by targeting podocytes and macrophages. Am J Physiol Ren Physiol 303:F339-F349

366. Taneyama C, Goto H, Benson KT, Unruh GK, Arakawa K (1991) Vagal involvement in the action of exogenous adenosine triphosphate on reflex renal sympathetic nerve activity. Anesth Analg 72: 351-358

367. Tang Y, Zhou L (2003) Characterization of adenosine A1 receptors in human proximal tubule epithelial (HK-2) cells. Receptors Channels 9:67-75

368. Taylor SRJ, Turner CM, Elliott JI, Hewitt R, Pickering M, Cook HT,

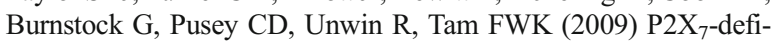
ciency ameliorates accelerated nephrotoxic nephritis in mice. J Am Soc Nephrol 20:1275-1281

369. Teitelbaum I (1992) Hormone signaling systems in inner medullary collecting ducts. Am J Physiol 263:F985-F990

370. Thomas J, Deetjen P, Ko WH, Jacobi C, Leipziger J (2001) P2 $\mathrm{Y}_{2}$ receptor-mediated inhibition of amiloride-sensitive short circuit current in M-1 mouse cortical collecting duct cells. J Membr Biol 183: $115-124$
371. Toma I, Bansal E, Meer EJ, Kang JJ, Vargas SL, Peti-Peterdi J (2008) Connexin 40 and ATP-dependent intercellular calcium wave in renal glomerular endothelial cells. Am J Physiol Regul Integr Comp Physiol 294:R1769-R1776

372. Toney GM, Vallon V, Stockand JD (2012) Intrinsic control of sodium excretion in the distal nephron by inhibitory purinergic regulation of the epithelial $\mathrm{Na}^{+}$channel. Curr Opin Nephrol Hypertens 21:52-60

373. Torres B, Zambon AC, Insel PA (2002) P2 $Y_{11}$ receptors activate adenylyl cyclase and contribute to nucleotide-promoted cAMP formation in MDCK- $\mathrm{D}_{1}$ cells. A mechanism for nucleotidemediated autocrine-paracrine regulation. J Biol Chem 277: 7761-7765

374. Tran E, Sun H, Fang Y (2012) Dynamic mass redistribution assays decode surface influence on signaling of endogenous purinergic P2Y receptors. Assay Drug Dev Technol 10:37-45

375. Turner C, Vonend O, Chan CM, Burnstock G, Unwin RJ (2003) The pattern of distribution of selected ATP-sensitive P2 receptor subtypes in normal rat kidney: an immunohistological study. Cells Tissues Org 175:105-117

376. Turner C, Ramesh B, Srai SKS, Burnstock G, Unwin R (2004) Altered P2 receptor expression in the Han:SPRD cy/+ rat, a model of autosomal dominant polycystic kidney disease. Cells Tissues Org 178:168-179

377. Turner CM, King BF, Srai KS, Unwin RJ (2007) Antagonism of endogenous putative $\mathrm{P} 2 \mathrm{Y}$ receptors reduces the growth of MDCK-derived cysts cultured in vitro. Am J Physiol Ren Physiol 292:F15-F25

378. Turner CM, Tam F, Lai P-C, Tarzi RM, Burnstock G, Pusey CD, Cook HT, Unwin RJ (2007) Increased expression of the pro-apoptotic ATP-sensitive $\mathrm{P}_{2} \mathrm{X}_{7}$ receptor in experimental and human glomerulonephritis. Nephrol Dial Transplant 22: 386-395

379. Turner CM, Elliott JI, Tam FW (2009) P2 receptors in renal pathophysiology. Purinergic Signal 5:513-520

380. Udagawa T, Hanaoka K, Kawamura M, Hosoya T (2012) Characteristics of spontaneous calcium oscillations in renal tubular epithelial cells. Clin Exp Nephrol 16:389-398

381. Unwin RJ, Bailey MA, Burnstock G (2003) Purinergic signaling along the renal tubule: the current state of play. News Physiol Sci 18:237-241

382. Vallon V (2008) P2 receptors in the regulation of renal transport mechanisms. Am J Physiol Ren Physiol 294:F10-F27

383. Vallon V, Rieg T (2011) Regulation of renal $\mathrm{NaCl}$ and water transport by the ATP/UTP/P2 $Y_{2}$ receptor system. Am J Physiol Ren Physiol 301:F463-F475

384. Vallon V, Mühlbauer B, Osswald H (2006) Adenosine and kidney function. Physiol Rev 86:901-940

385. van der Weyden L, Adams DJ, Morris BJ (2000) Capacity for purinergic control of renin promoter via $\mathrm{P}_{2} \mathrm{Y}_{11}$ receptor and cAMP pathways. Hypertension 36:1093-1098

386. Vargas F, Osuna A, Fernández-Rivas A (1996) Renal vascular reactivity to ATP in hyper- and hypothyroid rats. Experientia 52: 225-229

387. Vekaria RM (2004) Vesicular storage and release of ATP in a rat proximal tubule cell line. J Physiol 560:C17

388. Vekaria RM, Unwin RJ, Shirley DG (2006) Intraluminal ATP concentrations in rat renal tubules. J Am Soc Nephrol 17:1841-1847

389. Vekaria RM, Shirley DG, Sevigny J, Unwin RJ (2006) Immunolocalization of ectonucleotidases along the rat nephron. Am J Physiol Ren Physiol 290:F550-F560

390. Vitzthum H, Weiss B, Bachleitner W, Krämer BK, Kurtz A (2004) Gene expression of adenosine receptors along the nephron. Kidney Int 65:1180-1190

391. Vonend O, Oberhauser V, von Kügelgen I, Apel TW, Amann K, Ritz E, Rump LC (2002) ATP release in human kidney cortex and 
its mitogenic effects in visceral glomerular epithelial cells. Kidney Int 61:1617-1626

392. Vonend O, Grote T, Oberhauser V, von Kügelgen I, Rump LC (2003) P2Y-receptors stimulating the proliferation of human mesangial cells through the $\mathrm{MAPK}^{42 / 44}$ pathway. Br J Pharmacol 139:1119-1126

393. Vonend O, Turner C, Chan CM, Loesch A, Dell'Anna GC, Srai SK, Burnstock G, Unwin R (2004) Glomerular expression of the ATPsensitive $\mathrm{P}_{2} \mathrm{X}_{7}$ receptor in diabetic and hypertensive rat models. Kidney Int 66:157-166

394. Walker M III, Harrison-Bernard LM, Cook AK, Navar LG (2000) Dynamic interaction between myogenic and TGF mechanisms in afferent arteriolar blood flow autoregulation. Am J Physiol Ren Physiol 279:F858-F865

395. Wang J, Ouyang C, Chen X, Fu B, Lu Y, Hong Q (2008) STAT3 inhibits apoptosis of human renal tubular epithelial cells induced by ATP depletion/recovery. Nephron Exp Nephrol 108:e11-e18

396. Wang Y, Knowlton AA, Christensen TG, Shih T, Borkan SC (1999) Prior heat stress inhibits apoptosis in adenosine triphosphatedepleted renal tubular cells. Kidney Int 55:2224-2235

397. Wang YM, McRae JL, Robson SC, Cowan PJ, Zhang GY, Hu M, Polhill T, Wang Y, Zheng G, Wang Y, Lee VW, Unwin RJ, Harris DC, Dwyer KM, Alexander SI (2012) Regulatory T cells participate in CD39-mediated protection from renal injury. Eur J Immunol 42: 2441-2451

398. Weaver DR, Reppert SM (1992) Adenosine receptor gene expression in rat kidney. Am J Physiol 263:F991-F995

399. Wei Q, Wang J, Wang MH, Yu F, Dong Z (2004) Inhibition of apoptosis by $\mathrm{Zn}^{2+}$ in renal tubular cells following ATP depletion. Am J Physiol Ren Physiol 287:F492-F500

400. Weinbaum S, Duan Y, Satlin LM, Wang T, Weinstein AM (2010) Mechanotransduction in the renal tubule. Am J Physiol Ren Physiol 299:F1220-F1236

401. Welch BD, Carlson NG, Shi H, Myatt L, Kishore BK (2003) P2 $Y_{2}$ receptor-stimulated release of prostaglandin $\mathrm{E}_{2}$ by rat inner medullary collecting duct preparations. Am J Physiol Ren Physiol 285: F711-F721

402. Welch WJ (2002) Adenosine $A_{1}$ receptor antagonists in the kidney: effects in fluid-retaining disorders. Curr Opin Pharmacol 2:165-170

403. Welch WJ (2002) Adenosine type 1 receptor antagonists in fluid retaining disorders. Expert Opin Inv Drugs 11:1553-1562

404. Welch WJ, Solis G, Wilcox CS (2011) Adenosine receptors in the proximal tubule modulate deoxycorticosterone acetate (DOCA)-salt hypertension in mice. Hypertension 58:e60

405. Wellhauser L, Luna-Chavez C, D'Antonio C, Tainer J, Bear CE (2011) ATP induces conformational changes in the carboxylterminal region of ClC-5. J Biol Chem 286:6733-6741

406. Wengert M, Berto C Jr, Kaufman J, Leão-Ferreira LR, Paes-deCarvalho R, Lopes AG, Caruso-Neves C (2005) Stimulation of the proximal tubule $\mathrm{Na}^{+}$-ATPase activity by adenosine $\mathrm{A}_{2 \mathrm{~A}}$ receptor. Int J Biochem Cell Biol 37:155-165

407. Wierema TK, Postma CT, Houben AJ, Kroon AA, Thien T, Smits P, de Leeuw PW (1998) Adenosine-induced renal vasodilatation is prolonged in renal artery stenosis. J Hypertens 16:2109-2112

408. Wierema TK, Houben AJ, Kroon AA, Postma CT, Koster D, van Engelshoven JM, Smits P, de Leeuw PW (2005) Mechanisms of adenosine-induced renal vasodilatation in hypertensive patients. $\mathrm{J}$ Hypertens 23:1731-1736

409. Wildman SS, King BF (2008) P2X receptors: epithelial ion channels and regulators of salt and water transport. Nephron Physiol 108:60 67

410. Wildman SS, Unwin RJ, King BF (2003) Extended pharmacological profiles of rat $\mathrm{P} 2 \mathrm{Y} 2$ and rat $\mathrm{P} 2 \mathrm{Y} 4$ receptors and their sensitivity to extracellular $\mathrm{H}^{+}$and $\mathrm{Zn}^{2+}$ ions. Br J Pharmacol 140:1177-1186

411. Wildman SS, Marks J, Churchill LJ, Peppiatt CM, Chraibi A, Shirley DG, Horisberger JD, King BF, Unwin RJ (2005)
Regulatory interdependence of cloned epithelial $\mathrm{Na}^{+}$channels and P2X receptors. J Am Soc Nephrol 16:2586-2597

412. Wildman SS, Turner CM, Marks J, Shirley DG, King BF, Unwin RJ (2007) Differential regulation of renal $\mathrm{ENaC}$ by apical P2X and P2Y receptors. FASEB J 21:937.3

413. Wildman SS, Marks J, Turner CM, Yew-Booth L, PeppiattWildman CM, King BF, Shirley DG, Wang W, Unwin RJ (2008) Sodium-dependent regulation of renal amiloride-sensitive currents by apical P2 receptors. J Am Soc Nephrol 19:731-742

414. Wildman SS, Kang ES, King BF (2009) ENaC, renal sodium excretion and extracellular ATP. Purinergic Signal 5:481-489

415. Wildman SS, Boone M, Peppiatt-Wildman CM, Contreras-Sanz A, King BF, Shirley DG, Deen PM, Unwin RJ (2009) Nucleotides downregulate aquaporin 2 via activation of apical P2 receptors. J Am Soc Nephrol 20:1480-1490

416. Wilson PD, Hovater JS, Casey CC, Fortenberry JA, Schwiebert EM (1999) ATP release mechanisms in primary cultures of epithelia derived from the cysts of polycystic kidneys. J Am Soc Nephrol 10: 218-229

417. Xia SL, Wang L, Cash MN, Teng X, Schwalbe RA, Wingo CS (2004) Extracellular ATP-induced calcium signaling in mIMCD-3 cells requires both P2X and P2Y purinoceptors. Am J Physiol Ren Physiol 287:F204-F214

418. Xiao H, Shen HY, Liu W, Xiong RP, Li P, Meng G, Yang N, Chen X, Si LY, Zhou YG (2013) Adenosine $A_{2 A}$ receptor: a target for regulating renal interstitial fibrosis in obstructive nephropathy. PLoS One 8:e60173

419. Xie Y, Schafer JA (2008) Endogenous ATP release inhibits electrogenic $\mathrm{Na}^{+}$absorption and stimulates $\mathrm{Cl}^{-}$secretion in MDCK cells. Purinergic Signal 4:125-137

420. Xin C, Ren S, Pfeilschifter J, Huwiler A (2004) Heterologous desensitization of the sphingosine-1-phosphate receptors by purinoceptor activation in renal mesangial cells. $\mathrm{Br} \mathrm{J}$ Pharmacol 143:581-589

421. Xu C, Shmukler BE, Nishimura K, Kaczmarek E, Rossetti S, Harris PC, Wandinger-Ness A, Bacallao RL, Alper SL (2009) Attenuated, flow-induced ATP release contributes to absence of flow-sensitive, purinergic $\mathrm{Ca}_{\mathrm{i}}{ }^{2+}$ signaling in human ADPKD cyst epithelial cells. Am J Physiol Ren Physiol 296:F1464-F1476

422. Yamada H, Seki G, Taniguchi S, Uwatoko S, Suzuki K, Kurokawa $\mathrm{K}$ (1996) Mechanism of $\left[\mathrm{Ca}^{2+}\right]_{\mathrm{i}}$ increase by extracellular ATP in isolated rabbit renal proximal tubules. Am J Physiol 270:C1096C1104

423. Yamaguchi S, Umemura S, Tamura K, Iwamoto T, Nyui N, Ishigami T, Ishii $M$ (1995) Adenosine $A_{1}$ receptor mRNA in microdissected rat nephron segments. Hypertension 26:11811185

424. Yao J, Suwa M, Li B, Kawamura K, Morioka T, Oite T (2003) ATPdependent mechanism for coordination of intercellular $\mathrm{Ca}^{2+}$ signaling and renin secretion in rat juxtaglomerular cells. Circ Res 93: 338-345

425. Yap SC, Lee HT (2012) Adenosine and protection from acute kidney injury. Curr Opin Nephrol Hypertens 21:24-32

426. Zambon AC, Hughes RJ, Meszaros JG, Wu JJ, Torres B, Brunton LL, Insel PA (2000) P2 $\mathrm{Y}_{2}$ receptor of MDCK cells: cloning, expression, and cell-specific signaling. Am J Physiol Ren Physiol 279: F1045-F1052

427. Zambon AC, Brunton LL, Barrett KE, Hughes RJ, Torres B, Insel PA (2001) Cloning, expression, signaling mechanisms, and membrane targeting of $\mathrm{P} 2 \mathrm{Y}_{11}$ receptors in Madin Darby canine kidney cells. Mol Pharmacol 60:26-35

428. Zamir M, Phipps S (1987) Morphometric analysis of the distributing vessels of the kidney. Can J Physiol Pharmacol 65:2433-2440

429. Zarjou A, Agarwal A (2011) ATP as a death factor: purinergic signaling in renal epithelial-fibroblast cross talk. Am J Physiol Ren Physiol 300:F60-F61 
430. Zegarra-Moran O, Romeo G, Galietta LJ (1995) Regulation of transepithelial ion transport by two different purinoceptors in the apical membrane of canine kidney (MDCK) cells. Br J Pharmacol 114:1052-1056

431. Zhang L, Yang N, Wang S, Huang B, Li F, Tan H, Liang Y, Chen M, Li Y, Yu X (2011) Adenosine 2A receptor is protective against renal injury in MRL/lpr mice. Lupus 20:667-677

432. Zhang Y, Sanchez D, Gorelik J, Klenerman D, Lab M, Edwards C, Korchev Y (2007) Basolateral $\mathrm{P}_{2} \mathrm{X}_{4}$-like receptors regulate the extracellular ATP-stimulated epithelial $\mathrm{Na}^{+}$channel activity in renal epithelia. Am J Physiol Ren Physiol 292:F1734-F1740

433. Zhang Y, Sands JM, Kohan DE, Nelson RD, Martin CF, Carlson NG, Kamerath CD, Ge Y, Klein JD, Kishore BK (2008) Potential role of purinergic signaling in urinary concentration in inner medulla: insights from P2Y2 receptor gene knockout mice. Am J Physiol Ren Physiol 295:F1715-F1724
434. Zhang Y, Listhrop R, Ecelbarger CM, Kishore BK (2011) Renal sodium transporter/channel expression and sodium excretion in $\mathrm{P}_{2} \mathrm{Y}_{2}$ receptor knockout mice fed a high- $\mathrm{NaCl}$ diet with/without aldosterone infusion. Am J Physiol Ren Physiol 300:F657-F668

435. Zhang Y, Pop IL, Carlson NG, Kishore BK (2012) Genetic deletion of the $\mathrm{P} 2 \mathrm{Y}_{2}$ receptor offers significant resistance to development of lithium-induced polyuria accompanied by alterations in $\mathrm{PGE}_{2}$ signaling. Am J Physiol Ren Physiol 302:F70-F77

436. Zhao J, Wang H, Dai C, Wang H, Zhang H, Huang Y, Wang S, Gaskin F, Yang N, Fu SM (2013) P2X7 blockade attenuates lupus nephritis by inhibiting NLRP3/ASC/caspase-1 activation. Arthritis Rheum

437. Zhao Z, Kapoian T, Shepard M, Lianos EA (2002) Adenosineinduced apoptosis in glomerular mesangial cells. Kidney Int 61: $1276-1285$ 